STREAMFLOW, LAKE-FLOW PATTERNS, RAINFALL, AND QUALITY OF WATER AND SEDIMENT IN THE VICINITY OF A HAZARDOUS-WASTE LANDF ILL NEAR PINEWOOD, SOUTH CAROLINA, MARCH 1987 THROUGH EARLY JANUARY 1989

By Ronald A. Burt, Peter B. MoMahon, J. Frederick Robertson, and Douglas D. Nagle

U.S. GEOLOGICAL SURVEY

Water-Resources Investigations Report 91-4056

Prepared in cooperation with

SOUTH CAROLINA PUBLIC SERVICE AUTHORITY

Columbia, South Carolina 1991 


\section{U.S. DEPARTMENT OF THE INTERIOR \\ MANLEL LUJAN, JR., Secretary}

U.S. GEOLOGICAL SURVEY

Dallas L. Peck, Director

For additional information write tos

District Chief

U.S. Geological Survey

Stephenson Center-Suite 129 720 Gracern Road

Columbia, South Carolina 29210
Copies of this report may be purchased from:

U.S. Geological Survey Books and Open-File Reports Federal Center Box 25425 Denver, Colorado 80225 


\section{CONTENTS}

Page

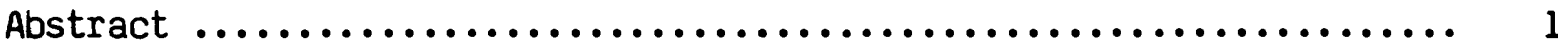

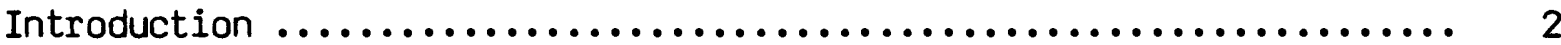

Purpose and scope $\ldots \ldots \ldots \ldots \ldots \ldots \ldots \ldots \ldots \ldots \ldots \ldots \ldots \ldots \ldots,{ }_{3}$

Study area $\ldots \ldots \ldots \ldots \ldots \ldots \ldots \ldots \ldots \ldots \ldots \ldots \ldots \ldots \ldots \ldots \ldots, \quad 3$

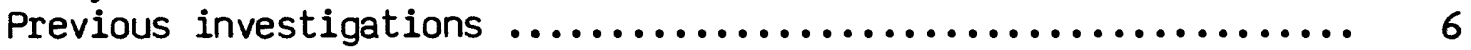

Patterns of surface drainage and lake flow $\ldots \ldots \ldots \ldots \ldots \ldots \ldots \ldots \ldots .6,6$

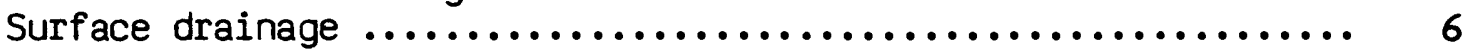

Lake flow and dye-tracer tests $\ldots \ldots \ldots \ldots \ldots \ldots \ldots \ldots \ldots \ldots \ldots \ldots, 8$

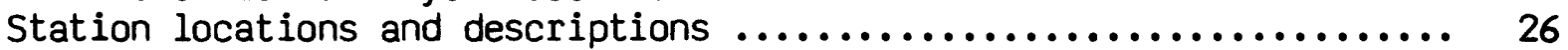

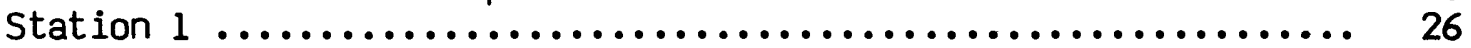

Station 2 (............................................... 26

Station 3 (................................................. 26

Station 4 (............................................... 27

Station 5 .............................................. 27

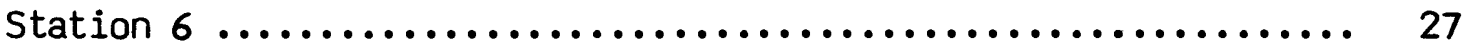

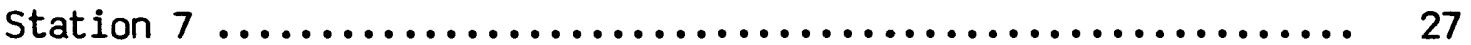

Streamflow and rainfall $\ldots . \ldots, \ldots, \ldots, \ldots, \ldots, \ldots, \ldots, \ldots, \ldots, \ldots, \ldots, 28$

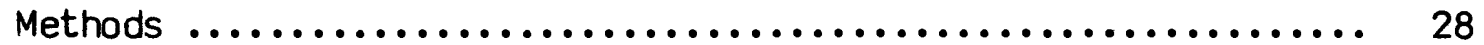

Stage measurements ................................ 28

Stream-discharge measurements $\ldots . \ldots \ldots \ldots \ldots \ldots \ldots \ldots \ldots \ldots, 29$

Stage-discharge relations $\ldots \ldots \ldots \ldots \ldots \ldots \ldots \ldots \ldots \ldots \ldots \ldots .29$

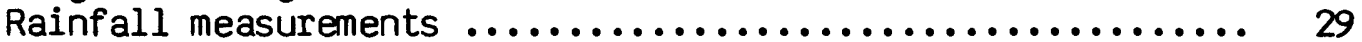

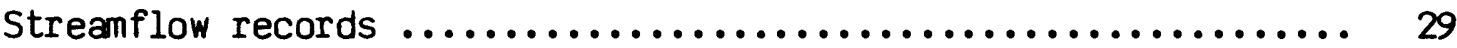

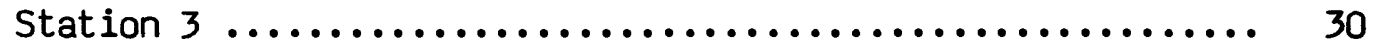

Station 4 .

Station 5 . ....................................... 39

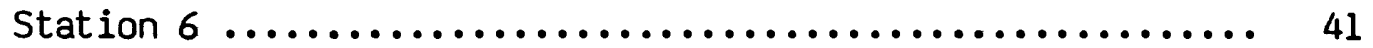

Rainfall records $\ldots \ldots \ldots \ldots \ldots \ldots \ldots \ldots \ldots \ldots \ldots \ldots \ldots \ldots \ldots \ldots, 45$

Discussion of streamf low and rainfall patterns $\ldots \ldots \ldots \ldots \ldots \ldots .45$

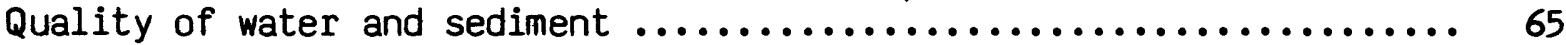

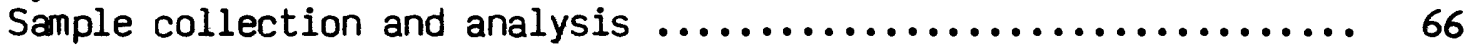

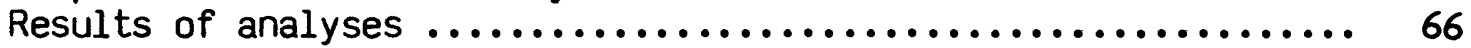

Inorganic constituents and properties in water $\ldots \ldots \ldots \ldots . .69$

Organic constituents in water $\ldots \ldots \ldots \ldots \ldots \ldots \ldots \ldots \ldots \ldots . .69 . \ldots$

Inorganic constituents in bottom sediment ............... 94

Organic constituents in bottom sediment ................ 94

Summary and conclusions...................................... 95

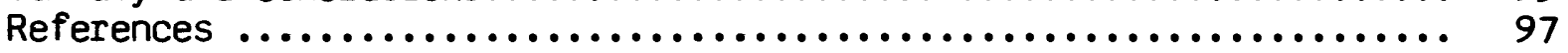

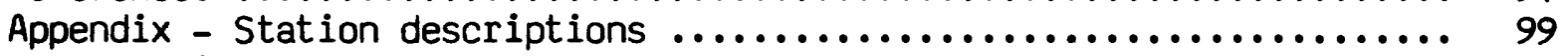

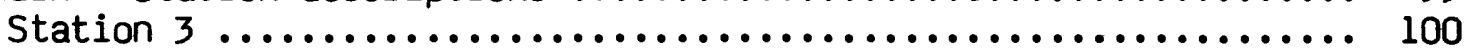

Station 4 ........................................... 102

Station 5 .

Station 6 .

Station 7 ......................................... 110 


\section{ILLUSTRATIONS}

Page

Figures 1-4. Maps showing:

1. Location of study area .................... 4

2. Study area with locations of data collection 5

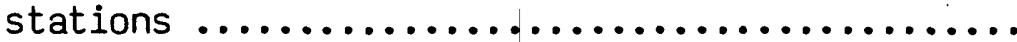

3. Drainage areas of streams, and location of topographic cross-section $T-T^{\prime} \ldots \ldots \ldots \ldots \ldots \ldots . \ldots 7$

4. Topographic profile $T-T^{\prime}$ adross study area ....... 9

5. Background fluorescence in Lake Marion during

low-flow conditions on November 10, 1987

prior to dye injection ................... 10

6-14. Maps showing the extent of the dye plume in Lake

Marion during low-flow conditions on:

6. November $12,1987,2$ days after dye injection ..... 11

7. November 13, 1987, 3 days after dye injection ..... 12

8. November $14,1987,4$ days after dye injection ..... 13

9. November $16,1987,6$ days after dye injection ..... 14

10. November $18,1987,8$ days after dye injection ..... 15

11. November $20,1987,10$ days after dye injection .... 16

12. November $24,1987,14$ days after dye injection .... 17

13. December $1,1987,21$ days after dye injection ..... 18

14. December $8,1987,28$ days after dye injection ..... 19

15. Map showing background fluorescence in Lake Marion

during high-flow conditions on March 30, 1987

prior to dye injection ..................... 20

16-19. Maps showing the extent of the dye plume in Lake

Marion during high-flow conditions on:

16. March $31,1987,0.5$ day after dye-injection ...... 21

17. April 1, 1987, 1 day after dye-injection ........ 22

18. April 2, 1987, 2 days after dye-injection ....... 23

19. April 3, 1987, 3 days after dye-injection ........ 24

20-23. Graphs showing stage-discharge rating curves for:

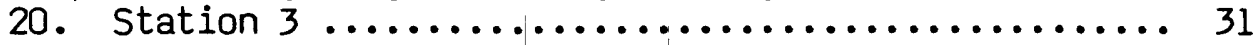

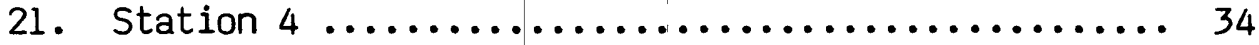

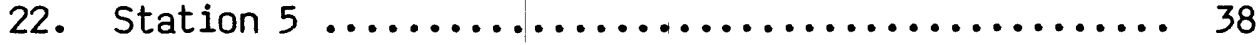

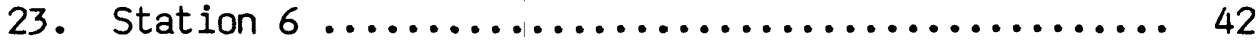

24. Streamflow at station 3 during October and

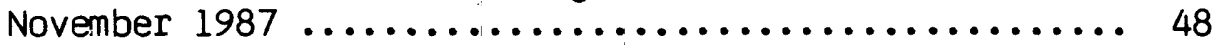

25-31. Graphs showing rainfall at station 7 and streamflow at

stations 3 and 6 during:

25. December 1987 and January $1988 \ldots \ldots \ldots \ldots \ldots \ldots \ldots . \ldots 49$

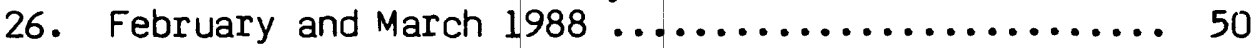

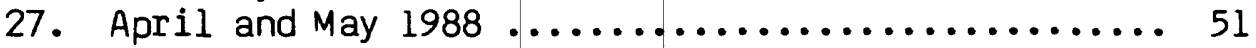

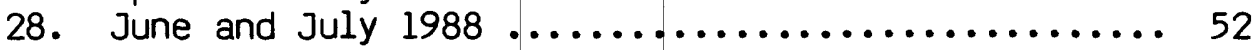

29. August and september $1988 \ldots \ldots \ldots \ldots \ldots \ldots \ldots \ldots \ldots \ldots \ldots$

30. October and November $1988 \ldots \ldots \ldots \ldots \ldots \ldots \ldots \ldots \ldots \ldots$

31. December 1988 and January $1989 \ldots \ldots \ldots \ldots \ldots \ldots \ldots . \ldots . \ldots 55$ 


\section{ILLUSTRATIONS---Continued}

Page

32. Graph showing streamflow at stations 4 and 5 during September and October 1987 ................... 56

33-40. Graphs showing rainfall at station 7 and streamflow at stations 4 and 5 during:

33. November and December $1987 \ldots \ldots \ldots \ldots \ldots \ldots \ldots \ldots$

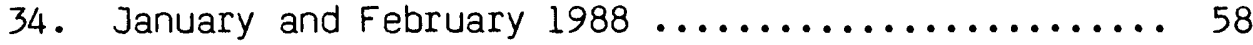

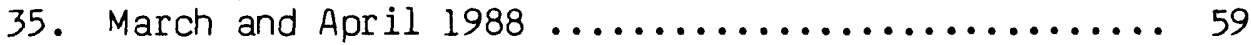

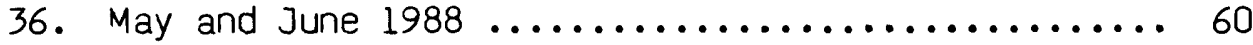

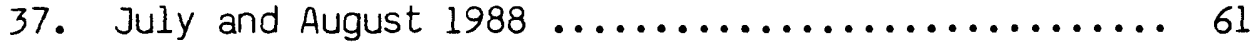

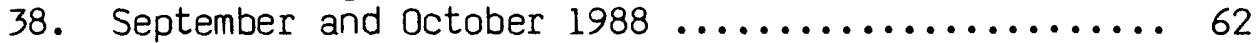

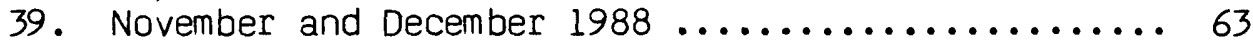

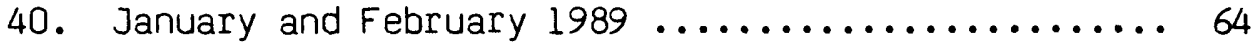

41. Trilinear plot of chemical analyses of water from stations 1 through $6 \ldots \ldots \ldots \ldots \ldots \ldots \ldots \ldots \ldots$. 91

\section{TABLS}

Table 1. Daily and monthly mean streamflow at Station $3 \ldots \ldots \ldots . . .32$

2. Daily and monthly mean streamflow at Station $4 \ldots \ldots \ldots \ldots . . . .35$

3. Daily and monthly mean streamflow at Station $5 \ldots \ldots \ldots \ldots . . . .39$

4. Daily and monthly mean streamflow at Station $6 \ldots \ldots \ldots \ldots . . .43$

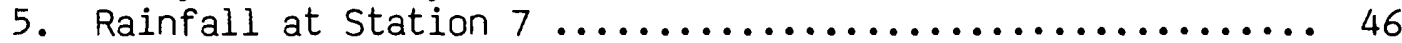

6. Ranges of selected properties and constituent concentrations in water and sediment ..............66 67

7. Results of analyses of surface water for inorganic

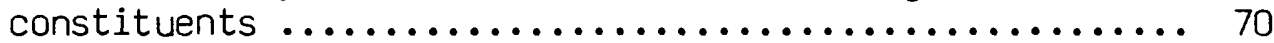

8. Results of analyses of surface water for purgeable organic compounds ........................ 77

9. Results of analyses of surface water for acid- and base/neutral-extractable organic compounds ......... 78

10. Results of analyses of surface water for organochlorine compounds ..................... 79

11. Results of analyses of streambed and lakebed sediments for major elements and trace metals ............. 80

12. Results of analyses of streambed and lakebed sediments for acid- and base/neutral-extractable

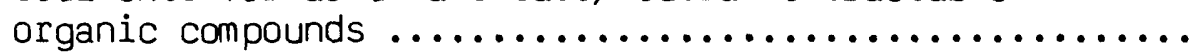

13. Results of analyses of streambed and lakebed sediments for organochlorine compounds 


\title{
STREAMFLOW, LAKE-FLOW PATTERNS, RAINFALL, AND QUALITY OF \\ WATER AND SEDIMENT IN THE VICINITY OF A HAZARDOUS-WASTE \\ LANDFILL NEAR PINEWOOD, SOUTH CAROLINA, MARCH 1987
}

THROUGH EARLY JANUARY 1989

\author{
By Ronald A. Burt, Peter B. MoMahon, \\ John $F$. Robertson, and \\ Douglas D. Nagle
}

\begin{abstract}
Streamflow characteristics, lake-flow patterns, rainfall, water quality, and sediment composition were studied in the vicinity of a hazardous-waste landfill near Pinewood, South Carolina from March 1987 to January 1989 to characterize natural background conditions, to compare background conditions within areas influenced by runoff from the landfill, and to establish a data base against which future data can be compared. The study was done as part of a cooperative effort between the U.S. Geological Survey and the South Carolina Public Service Authority.

Dye-tracer tests in Lake Marion, conducted under both high-inflow and low-inflow conditions, demonstrated that water discharging to the lake from streams that cross the landfill site flows southeastward, along the eastern shore of the lake. This would be the transport path for any potential contaminants from the landfill that might reach the lake.

Instantaneous streamflows in three small streams that drain the study area ranged from 0.00 to $9.8 \mathrm{ft}^{3} / \mathrm{s}$ (cubic feet per second), and monthly mean flows ranged from 0.00 to $1.7 \mathrm{ft} / \mathrm{s}$. Annual meąn streamflows during calendar year 1988 were $0.08,0.69$, and $0.41 \mathrm{ft}^{3} / \mathrm{s}$ at the three sites with complete records for the year. Stream baseflows ranged from 0.00 to 1.0 $\mathrm{ft} / \mathrm{s}$.

Annual rainfall at the centrally located raingage totaled 34.9 inches for calendar year 1988. Minimum monthly rainfall was 0.72 inch in June 1988, and maximum monthly rainfall was 6.22 inches in September 1988.

Significant differences in the inorganic chemical composition of water and bottom sediments between background stream stations and stream stations downstream of the landfill indicate that land use at the landfill may be affecting the streams, although the effects seem to be related to earth-moving activities and resulting sediment transport and leaching rather than to hazardous-waste disposal. Concentrations of calcium (ranging from 4.6 to $140 \mathrm{mg} /$ (milligrams per liter) and sulfate (ranging from 16 to 350 $\mathrm{mg} / \mathrm{L}$ ) in water downstream from the landfill exceeded background levels for
\end{abstract}


calcium (ranging from 1.6 to $6.0 \mathrm{mg} /$ ) and for sulfate (ranging from 3.2 to $11 \mathrm{mg} / \mathrm{L}$. The $\mathrm{pH}$ at one downstream site ranged from 4.86 to 6.55 and was somewhat lower than the $\mathrm{pH}$ at background stations (ranging from 6.21 to 6.80). High concentrations of sulfate and low pH probably are a result of oxidation of pyrite in spoil piles on the landfill. The $\mathrm{pH}$ at the other downstream site ranged from 6.77 to 7.26 and was higher than that at background stations indicating that a source of alkalinity is available to the stream. Maximum concentrations of some trace metals in water downstream from the landfill were higher than background concentrations. Downstream concentrations of zinc were as high as $120 \mathrm{ug} / \mathrm{h}$ (micrograms per liter) compared to less than $10 \mathrm{ug} / \mathrm{L}$ at the background stations, nickel was as high as $48 \mathrm{ug} / \mathrm{L}$ compared to a background concentration of $11 \mathrm{ug} / \mathrm{h}$, and chromium was as high as $36 \mathrm{ug} / \mathrm{L}$ compared to a background concentration of $3 \mathrm{ug} / \mathrm{L}$. Maximum concentrations of some trace metals in streambed sediments downstream from the landfill were also higher than concentrations at background stations. Downstream concentrations of zinc were as high as 44 $\mathrm{mg} / \mathrm{kg}$ (milligrams per kilogram) of sediment compared to $24 \mathrm{mg} / \mathrm{kg}$ at background stations, nickel was as high as $13 \mathrm{mg} / \mathrm{kg}$ compared to $7 \mathrm{mg} / \mathrm{kg}$, chromium was as high as $190 \mathrm{mg} / \mathrm{kg}$ compared to $54 \mathrm{mg} / \mathrm{kg}$, and vanadium concentrations were as high as $58 \mathrm{mg} / \mathrm{kg}$ compared to $42 \mathrm{mg} / \mathrm{kg}$ at background stations. Differences in trace metal concentrations were relativley small at the lake sites.

Anthropogenic organic compounds, including phenol and organochlorine compounds, were detected in sediments at the stream sites and lake sites. These were generally as prevalent at background sites as at sites downstream from the landfill, indicating that sources other than the landfill exist or have existed for these compounds. The concentration of phenol was as high as $7,900 \mu \mathrm{g} / \mathrm{kg}$ (microgram per kilogram) at one background station, but was below detection limit at the other sites. Dichlorodiphenyl dichloroethane and dichloro-2, 2-bis (p-chlorophenyl)-ethylene were detected at all sites, with concentrations as high as 65 and $54 \mu \mathrm{g} / \mathrm{kg}$ respectively.

Polychlorinated biphenyls were detected $(47 \mu \mathrm{g} / \mathrm{kg}$ ) only in the sediments at the background lake station. Chlordane (as high as $13 \mu \mathrm{g} / \mathrm{kg}$ ), dieldrin $(0.4$ $\mu \mathrm{g} / \mathrm{kg}$ ), and toxaphene ( $20 \mu \mathrm{g} / \mathrm{kg}$ ) were detected exclusively in sediment at stations downstream from the landfill. Concentrations of these organics in the surface water were below detection limits.

\section{INTRDDUCTION}

A hazardous-waste landfill near Pinewood, S.C., is one of two landfills in the southeastern United States permitted to accept hazardous waste. Since 1977, approximately 1 billion pounds of wastes, including ignitable, corrosive, acutely hazardous, reactive, and toxic materials, have been buried at the 279-acre site.

Although considerable effort has been expended in the past to characterize the geohydrology of the immediate site, little is known about how the landfill fits into the regional geohydrological setting. Concerns have been raised about the potential for contamination of ground water and 
surface water by leakage from the site. To address these concerns, the U.S. Geological Survey, in cooperation with the South Carolina Public Service Authority, is conducting a 3-year study designed to characterize the geohydrology, streamflow, lake-flow patterns, water quality, and sediment quality of an approximately $16-\mathrm{mi}^{2}$ area surrounding the hazardous-waste landfill near Pinewood: The landfill is located within 1,200 ft of Lake Marion, South Carolina's largest reservoir. The regional extent of aquifers, the directions of ground-water flow, and the interaction between ground water and surface water are factors that determine the effects of potential contaminants in the vicinity of the landfill.

\section{Purpose and Scope}

This report presents a characterization of natural background conditions, compares background conditions with those in areas influenced by runoff from the landfill, and, most importantly, establishes a data base with which future data can be compared. The report includes data and descriptions about surface-water drainage patterns, lake-flow patterns under both high- and low-inflow conditions, streamflow, estimates of baseflow contribution to streamflow, rainfall, and chemical and physical

characteristics of water and bottom sediments collected at selected stream and lake sites for the period March 1987 through early January 1989.

\section{Study Area}

The study area (figs. 1 and 2) is located in the central part of South Carolina, in Sumter County, and includes an approximately $16-\mathrm{mi}^{2}$ area surrounding the landfill site that is located about $2 \mathrm{mi}$ (miles) northwest of Rimini, the nearest town, and $5 \mathrm{mi}$ southwest of Pinewood. The study area is in the Middle Coastal Plain physiographic province that is characterized by expansive uplands with subdued relief that separate flat swampy river valleys. It includes parts of the Santee River valley and adjacent uplands. The uplands exhibit gently undulating topographic relief of 25 to $50 \mathrm{ft}$ and contain low-gradient streams; many flat areas contain Carolina bays, which are shallow swampy, oval depressions as large as 2,000 ft across. The Santee River valley is separated from the upland part of the study area by a steep (10- to 20-percent grade) erosional escarpment 70 to $80 \mathrm{ft}$ high. Streams cut the escarpment with gradients of 1 to 5 percent. South of the landfill most of the river valley has been flooded to form Lake Marion, the largest reservoir in South Carolina, covering 110,600 acres to an average depth of $12.5 \mathrm{ft}$. The study area includes about $6 \mathrm{mi}^{2}$ of the upper reaches of Lake Marion, approximately 60 percent of which are characterized by dense emergent stands of live and dead trees. The lake, formed by completion of Wilson Dam in 1941, is owned and managed by the South Carolina Public Service Authority. Lake Marion is used for hydropower generation, flood control, and recreation (South Carolina Water Resources Commission, 1983). To the northwest of the landfill, the valley of the Santee River and its tributaries, the Wateree and Congaree Rivers, contains riverine wetlands and 


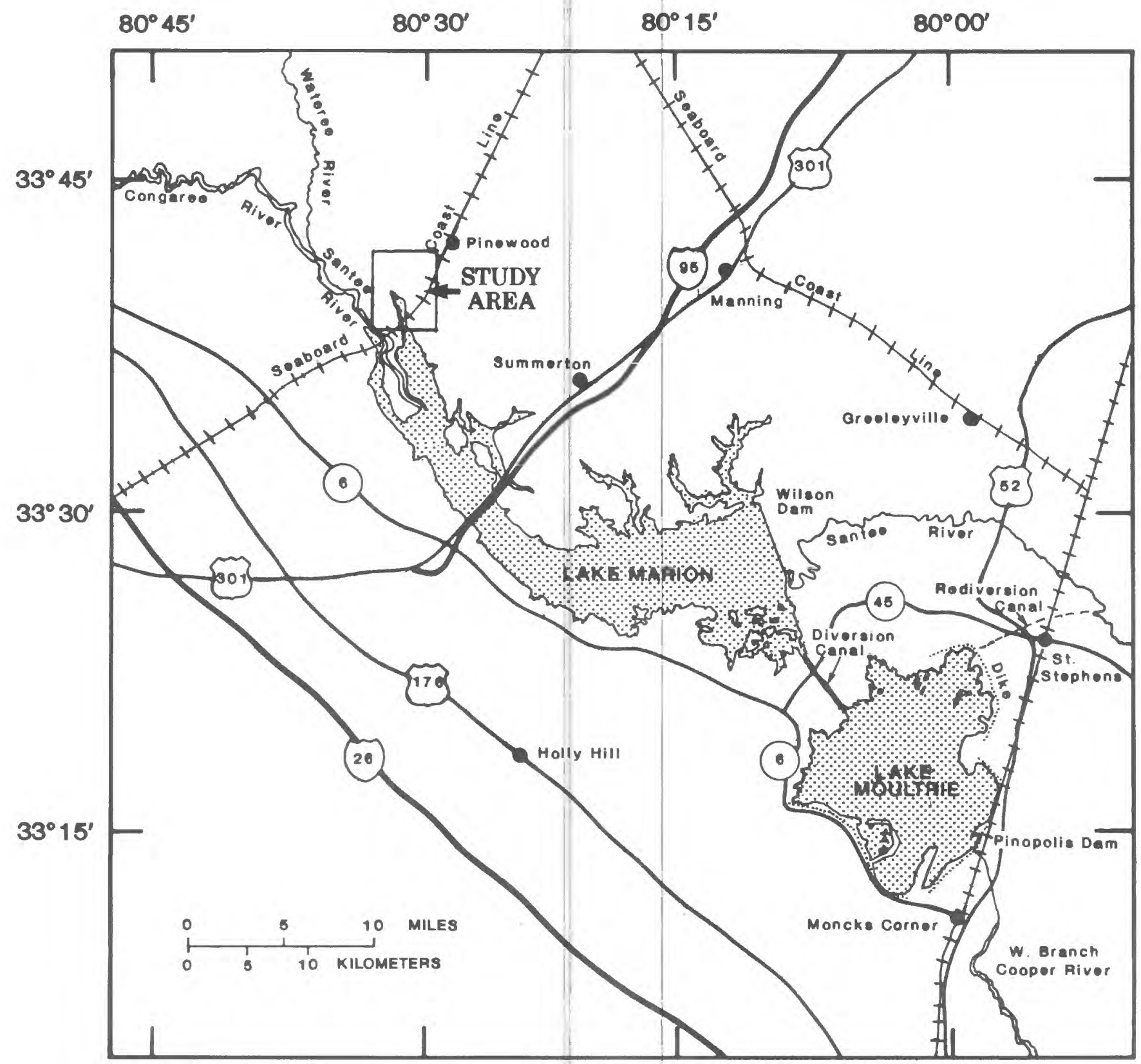

Figure 1.--Location of study area. 


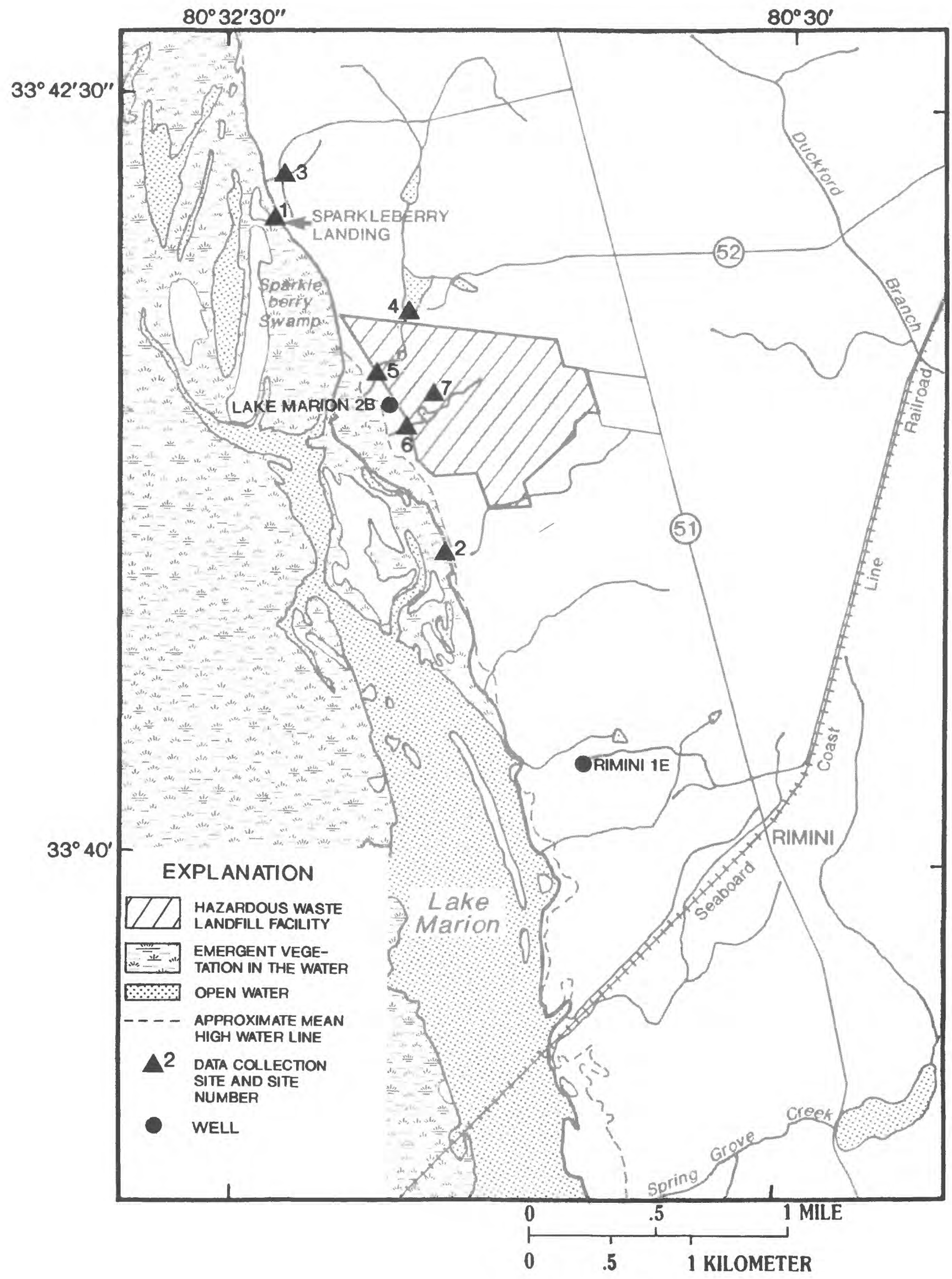

Figure 2.--Study area with locations of data collection stations. 
bottomland forests. The uplands within the study area are approximately 50 percent cleared for agriculture, and 50 percent forested. The landfill occupies 279 acres and is predominantly cleared.

The study area is characterized by a warm temperate climate with an average annual temperature of $62{ }^{\circ} \mathrm{F}$ (degrees Fahrenheit) and an average annual rainfall of 46 inches (South Carolina Water Resources Commission, 1983). Highest rainfall generally occurs during summer months, and lowest rainfall is during fall and early winter, although during the summer months of the study period the area experienced drought conditions.

\section{Previous Investigations}

Previous studies regarding the geology, hydrology, and water quality of the study area are described in reports by government agencies and consultants. Cooke (1936) included the study area in his description of the geology of the South Carolina Coastal Plain. Park (1980) described the geohydrology of Sumter county. A series of seven reports regarding geohydrology of the landfill site was prepared by Aware, Inc. (1985a, 1985b, 1985c, 1985d, 1985e, 1985f, 1985g). EBASCO (1986) produced a report for the South Carolina Budget and Control Board that included a discussion of geohydrological and environmental information available at the time of writing. Peckham (1986) discussed the geohydrology of the landfill site with regard to a ground-water monitoring program. The Part B Permit application (Enviromental Technology Engineering, Inc. 1987) submitted by the site operator as required by South Carolina hazardous-waste management regulations contains extensive geological and geohydrological data specif ic to the landfill site. Instantaneous streamflow measurements, without stage measurements, for several of the stations described in this report are on file at the South Carolina Public Service Authority (John Inabinet, oral commun., 1987). A water-quality monitoring program for Lake Marion and its tributaries was described by Inabinet (1985).

\section{PATTERNS OF SURFACE DRAINAGE AND LAKE FLOW}

Patterns of surface-water drainage determine the areas that could be affected by contaminant transport from the landfill by surface water. An understanding of flow patterns in nearby streams and in Lake Marion is necessary for choosing sampling locations to represent background conditions and conditions within the influence of drainage from the landfill.

\section{Surface Drainage}

The study area is bisected by a topographic divide that approximately parallels Sumter County Road 43-51 (fig. 3). West of the divide, runoff drains directly to Lake Marion in several small westward flowing streams and sloughs. East of the divide, runoff flows to Spring Grove Creek and its tributary, Duckford Branch. Spring Grove Creek discharges to Lake Marion about $2 \mathrm{mi}$ south of the landfill. 


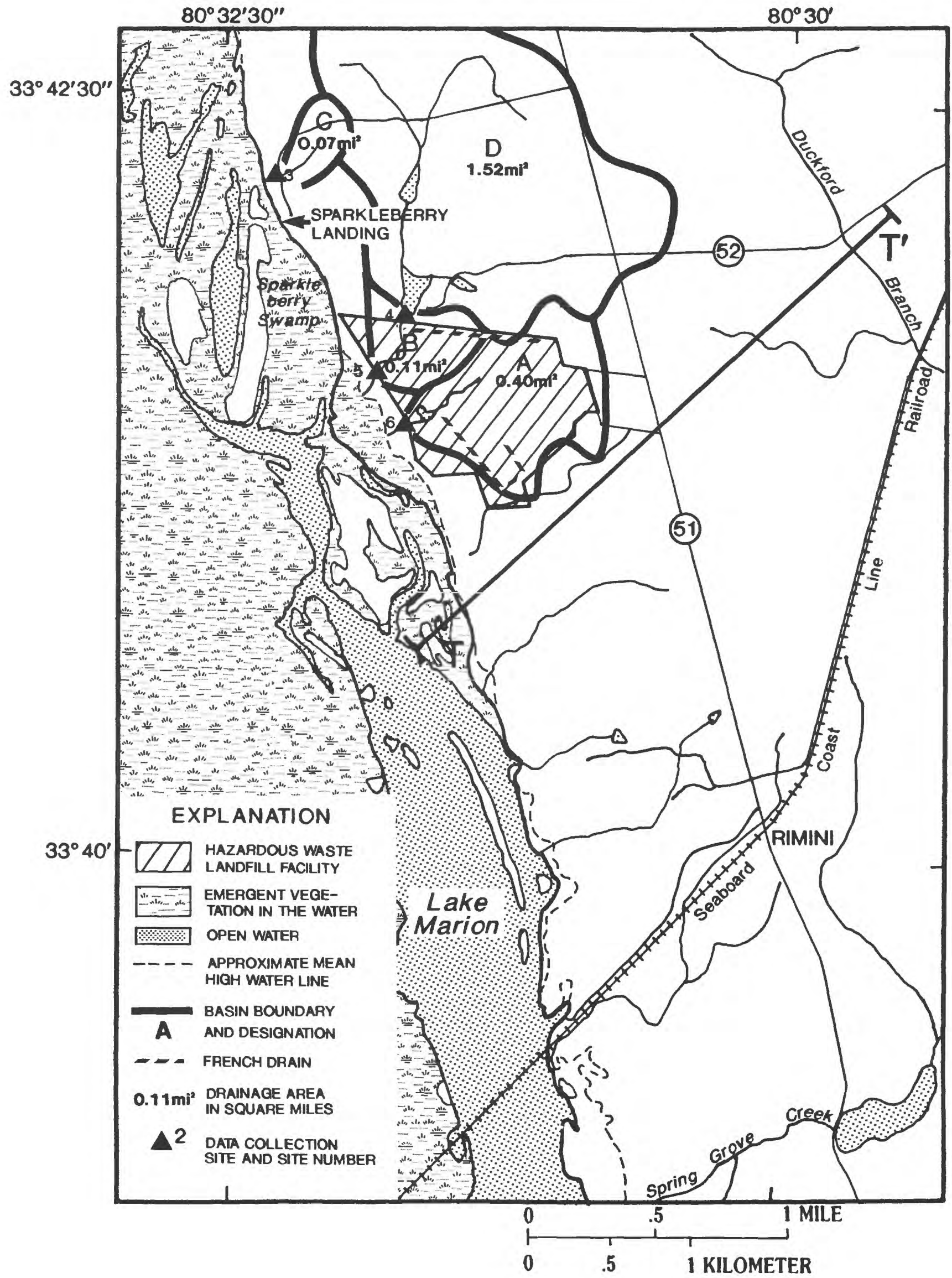

Figure 3.--Drainage areas of streams, and location of topographic cross-section T-T' 
Drainage basins of four streams in the vicinity of the landfill are delineated in figure 3. The basins, labeled $A, B, C$, and $D$, were delineated to correspond to drainage upstream of stream-gaging stations. Two of the gages are on one stream; basin D represents drainage upstream of the upper gage and basin B represents intervening drainage between the two gages. The unlabeled drainage areas correspond to drainage to Lake Marion from small streams and undefined channels. The size of each gaged drainage basin is also shown in figure 3.

A topographic profile along section T- ${ }^{*}$ (figs. 3 and 4 ) illustrates the steep grade from the upland part of the basin to the river valley. The profile shows a mild grade east of the main divide.

The landfill property lies entirely west of the surface divide. About 65 percent of the landfill property lies within drainage basin $A$, as designated in figure 3, which drains to Lake Marion through a small stream at the western boundary of the landfill. The rest of the landfill is mostly included in drainage basin B, which drains to Lake Marion through another small stream that crosses the northwestern corner of the landfill property.

The topography of the landfill property has been changed during the period of study because of continuous landfill construction operations; therefore, the boundary between drainage basins $A$ and $B$ has probably been altered.

\section{Lake Flow and Dye-Tracer Tests}

The movement of water through the upper reaches of Lake Marion can be described as flow driven by the gradient developed between the Santee River, which flows between well-defined natural leyees, and the lake. The lake flow is also affected by discharges from small streams that enter the lake around its perimeter. Wind generally has a minimal influence on flow in this part of the lake because of the shelter provided by stands of emergent trees. Patterns of flow in the upper $6 \mathrm{mi}^{2}$ of Lake Marion, near the landfill site, were delineated by two dye-tracer tests. One test was done during a period of high inflow into the lake and the other during low inflow. The purpose of the tests was to determine the flowpaths that water discharged from streams that drain the landfill site might follow in the upper reaches of Lake Marion.

The method of delineating lake-flow patterns with a dye tracer involves injecting a solution of rhodamine WT liquid|dye into the lake and then monitoring the dye concentration with a fluorometer at several stations located on the lake. A network of 35 dye-monitoring stations was set up in the northeastern part of Lake Marion for this study. Twenty-four of the stations are shown in figures 5-19; the others are located south of the map boundary. The same station locations were used for both the high-flow and low-flow observations; however, all stations were not used for each of the events. Prior to injection of the dye, fluorometer measurements of the lake water were made at several of the dye monitoring stations to determine the background fluorescence levels. Mean background fluorescence for the 


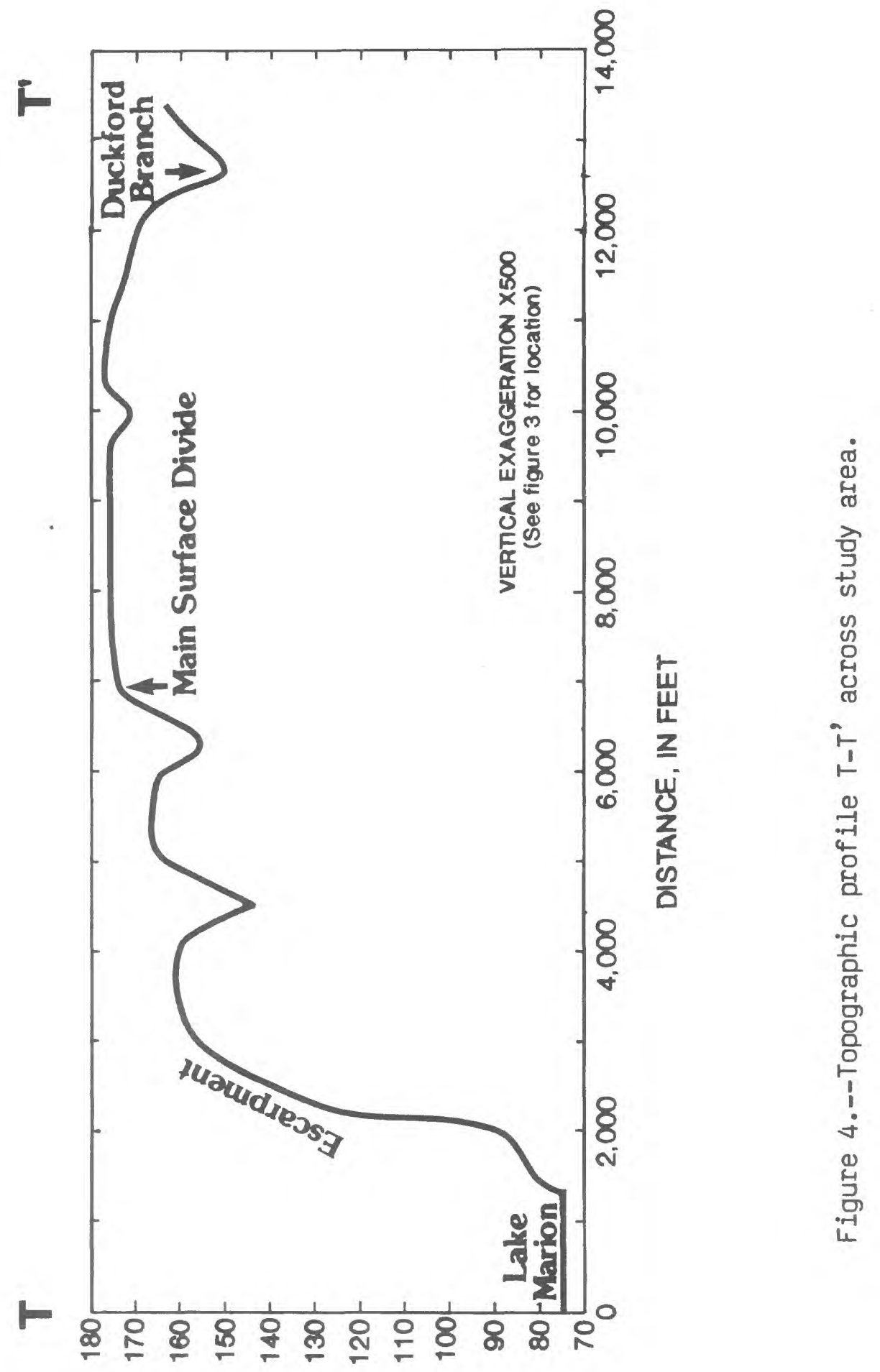

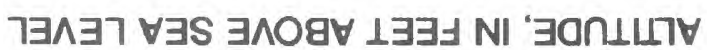




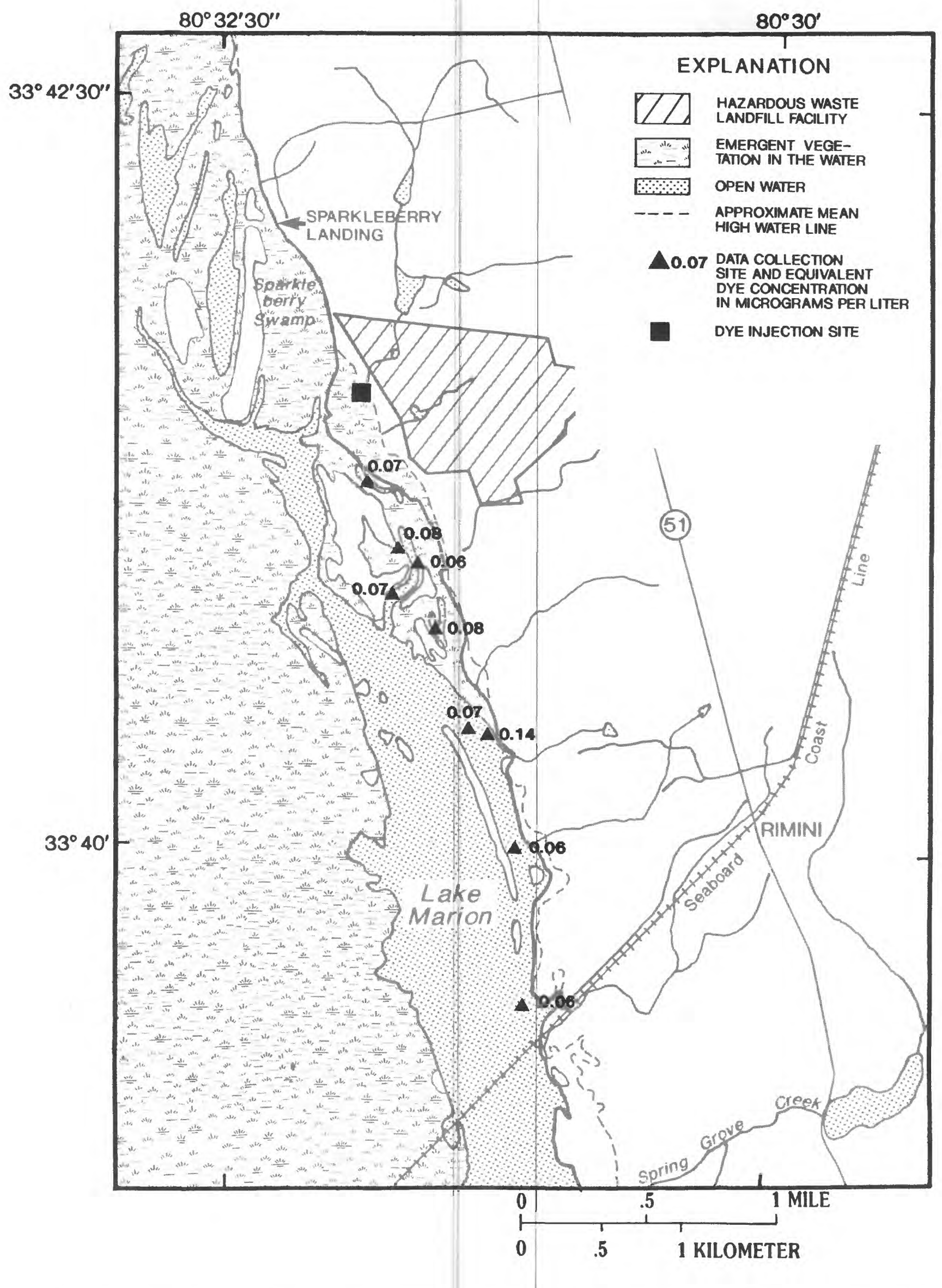

Figure 5.--Background fluorescence in Lake Marion during low-flow conditions on November 10, 1987 prior to dye injection. 


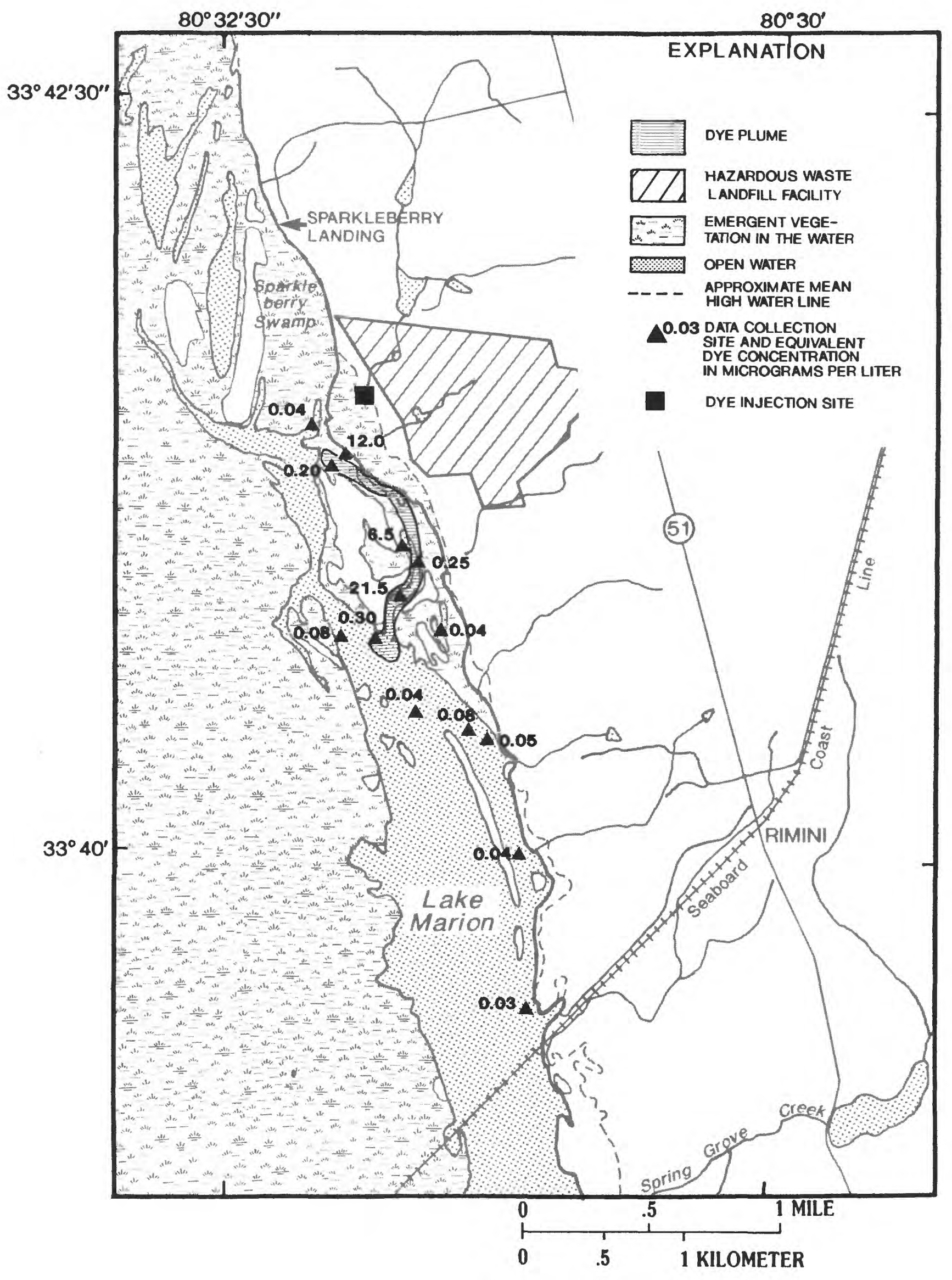

Figure 6.--The extent of dye plume in Lake Marion during low-flow conditions on November 12, 1987, 2 days after dye injection. 


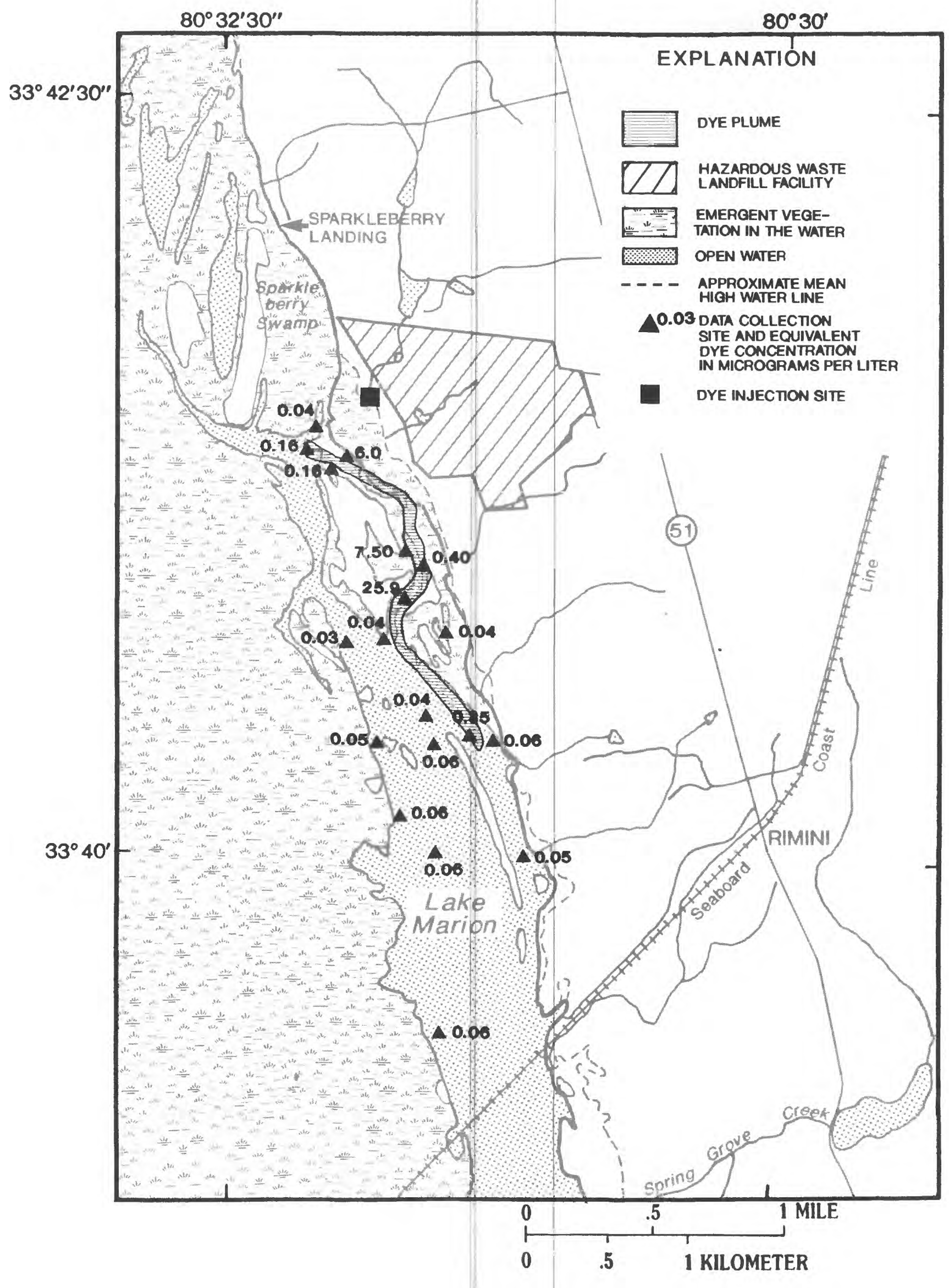

Figure 7.--The extent of dye plume in Lake Marion during low-flow conditions on November 13, 1987, 3 days after dye injection. 


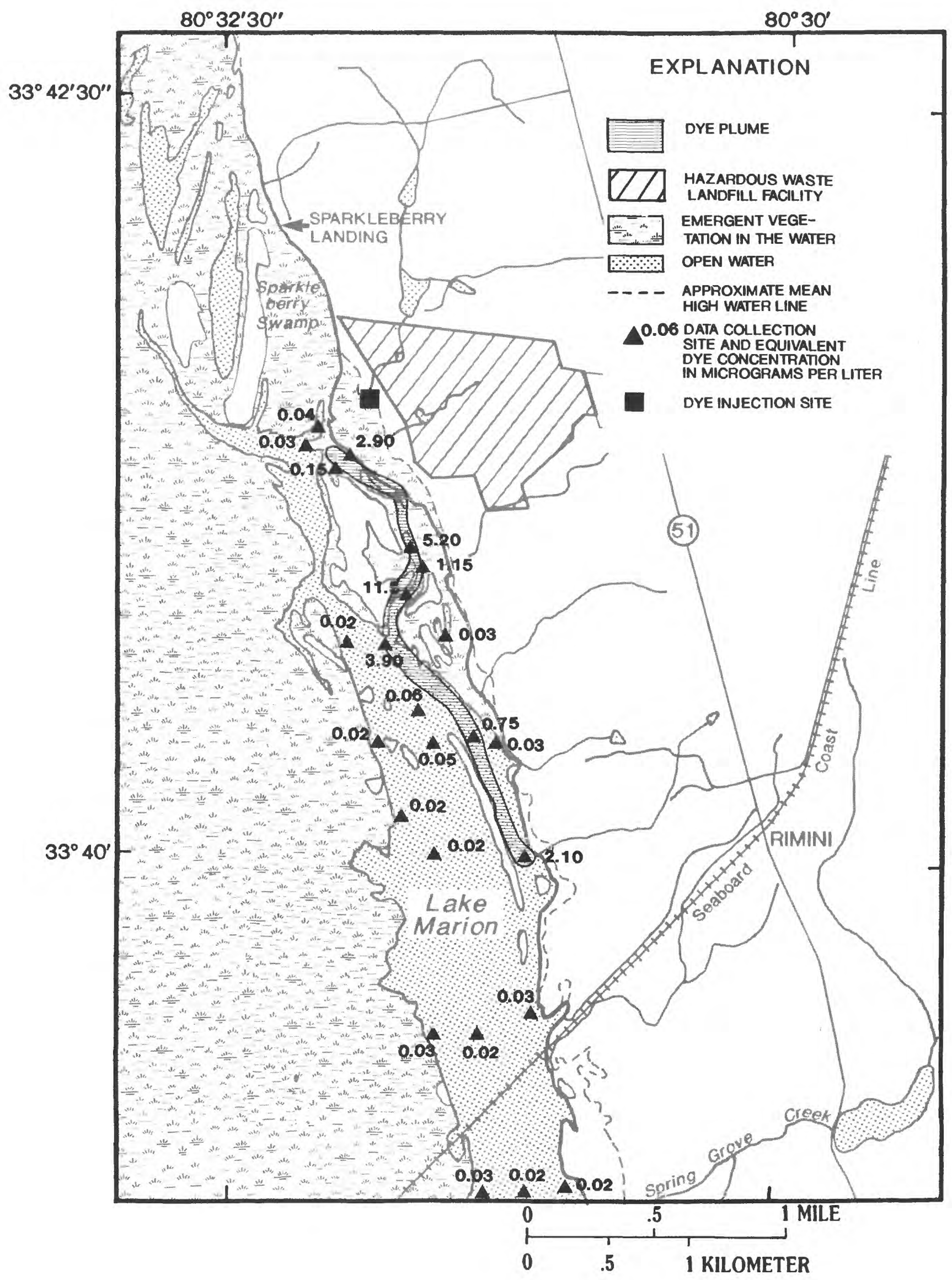

Figure 8.--The extent of dye plume in Lake Marion during low-flow conditions on November 14, 1987, 4 days after dye injection. 


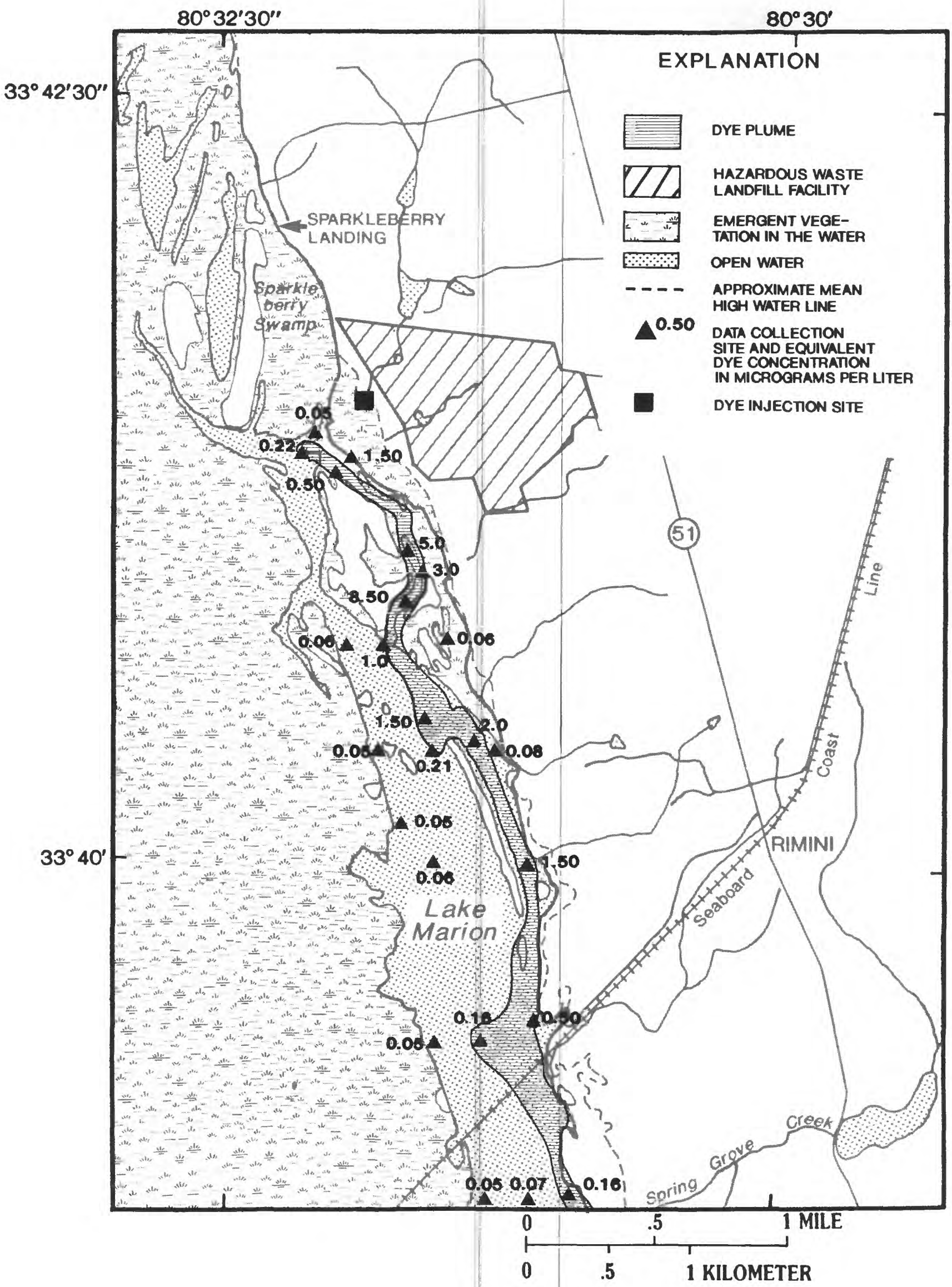

Figure 9.--The extent of dye plume in Lake Marion during low-flow conditions on November 16, 1987, 6 days after dye injection. 


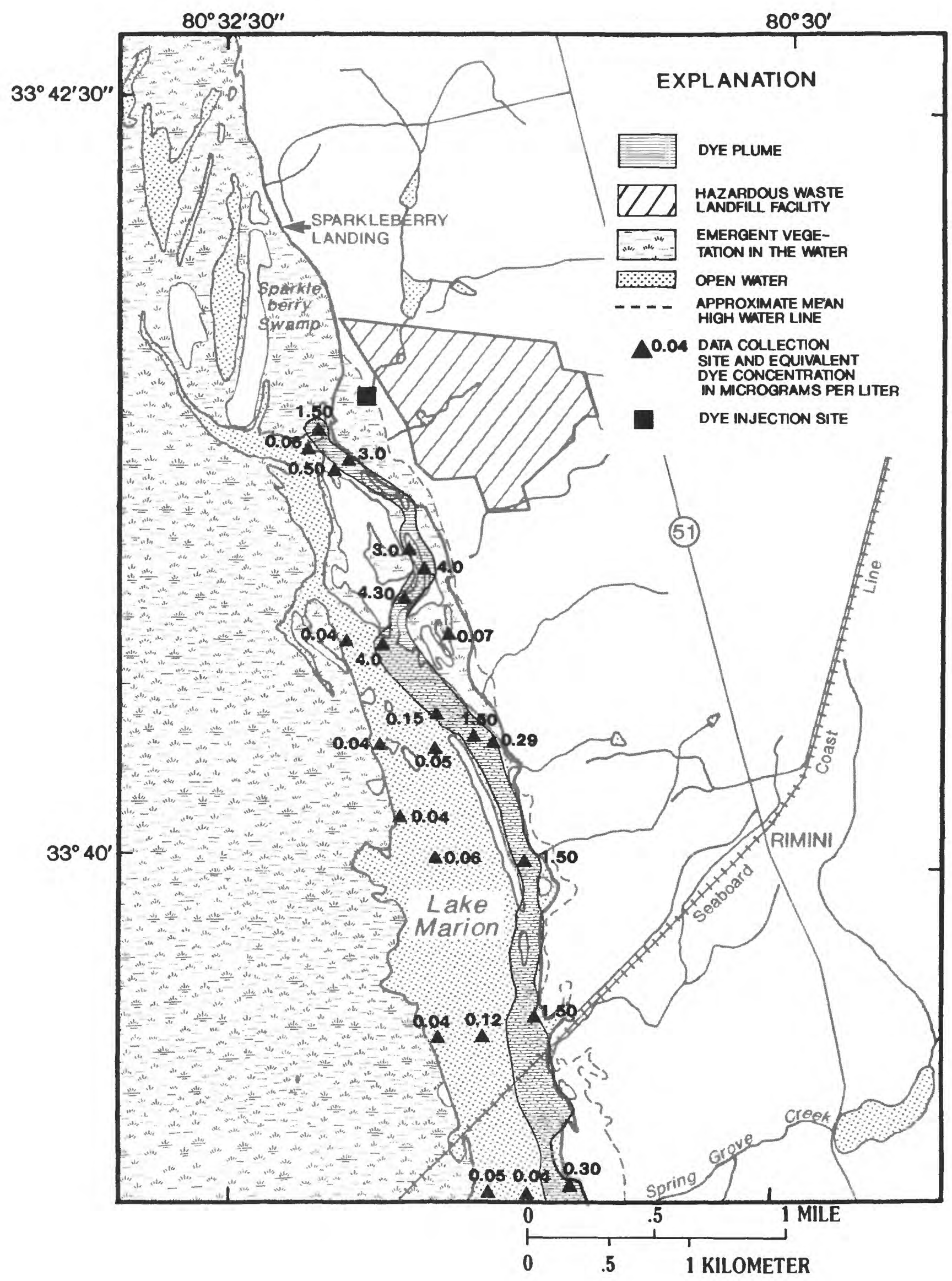

Figure 10.--The extent of dye plume in Lake Marion during low-flow conditions on November 18, 1987, 8 days after dye injection. 


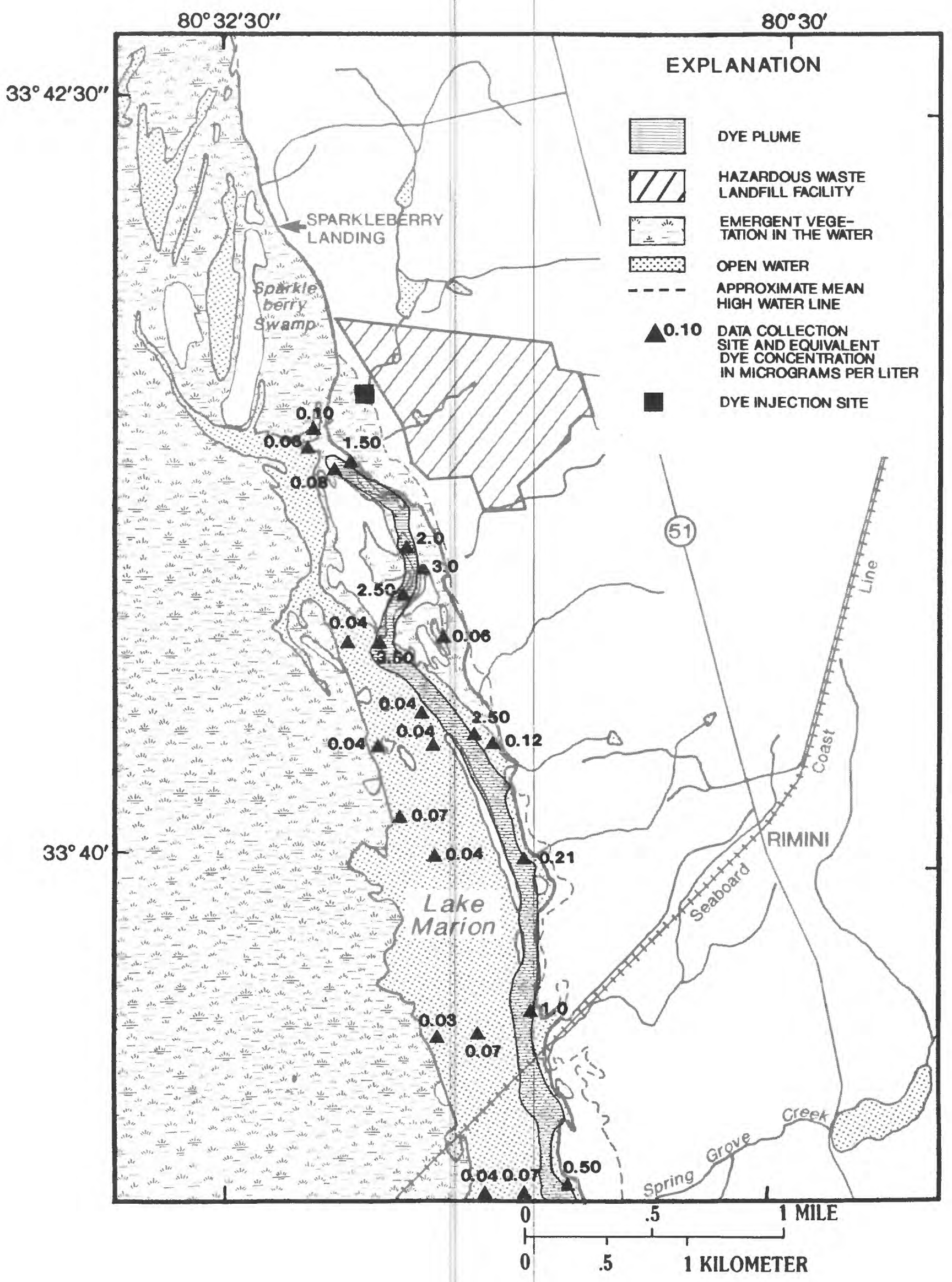

Figure 11.--The extent of dye plume in Lake Marion during low-flow conditions on November $20,1987,10$ days after dye injection. 


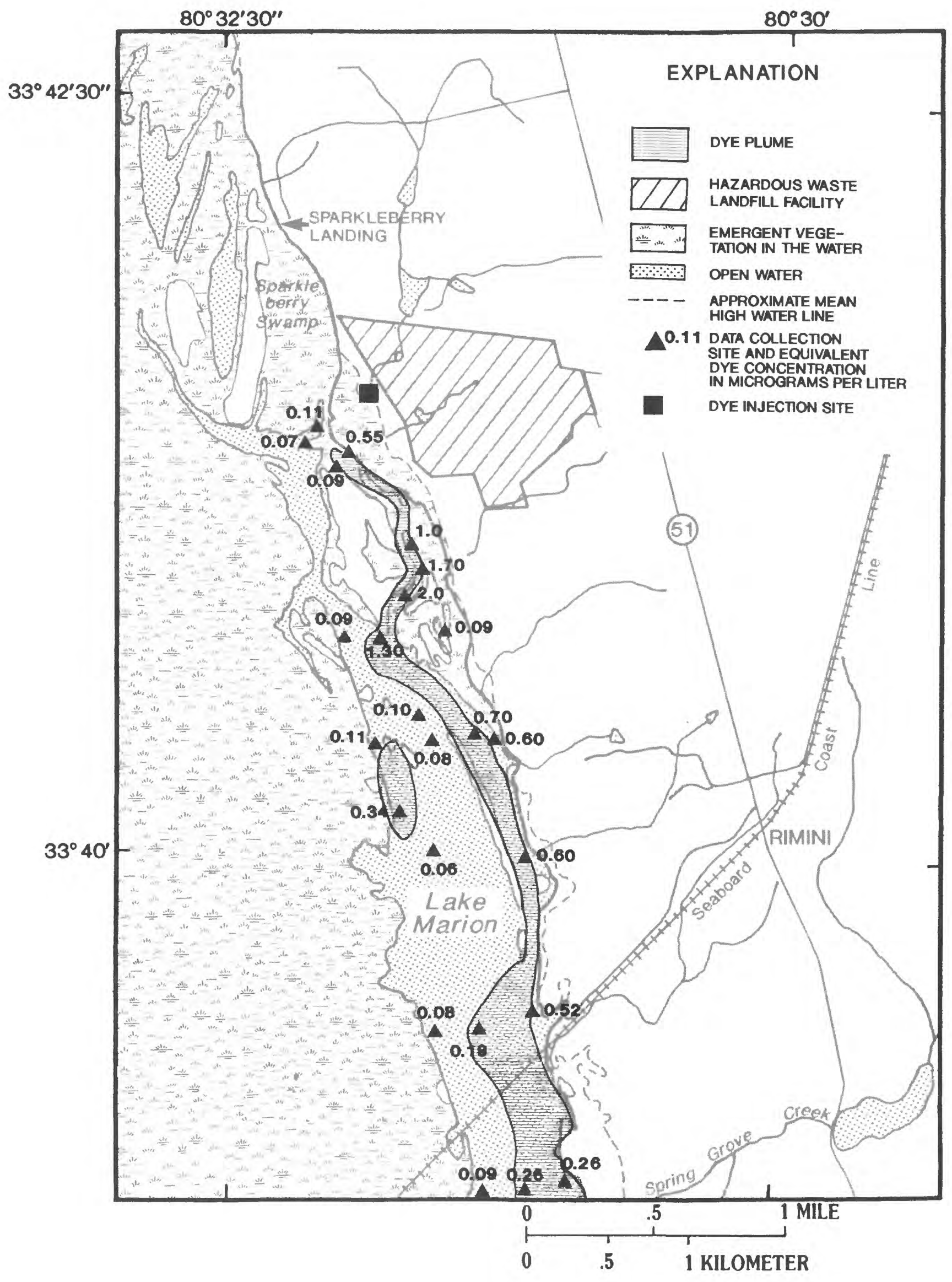

Figure 12.--The extent of dye plume in Lake Marion during low-flow conditions on November 24, 1987, 14 days after dye injection. 


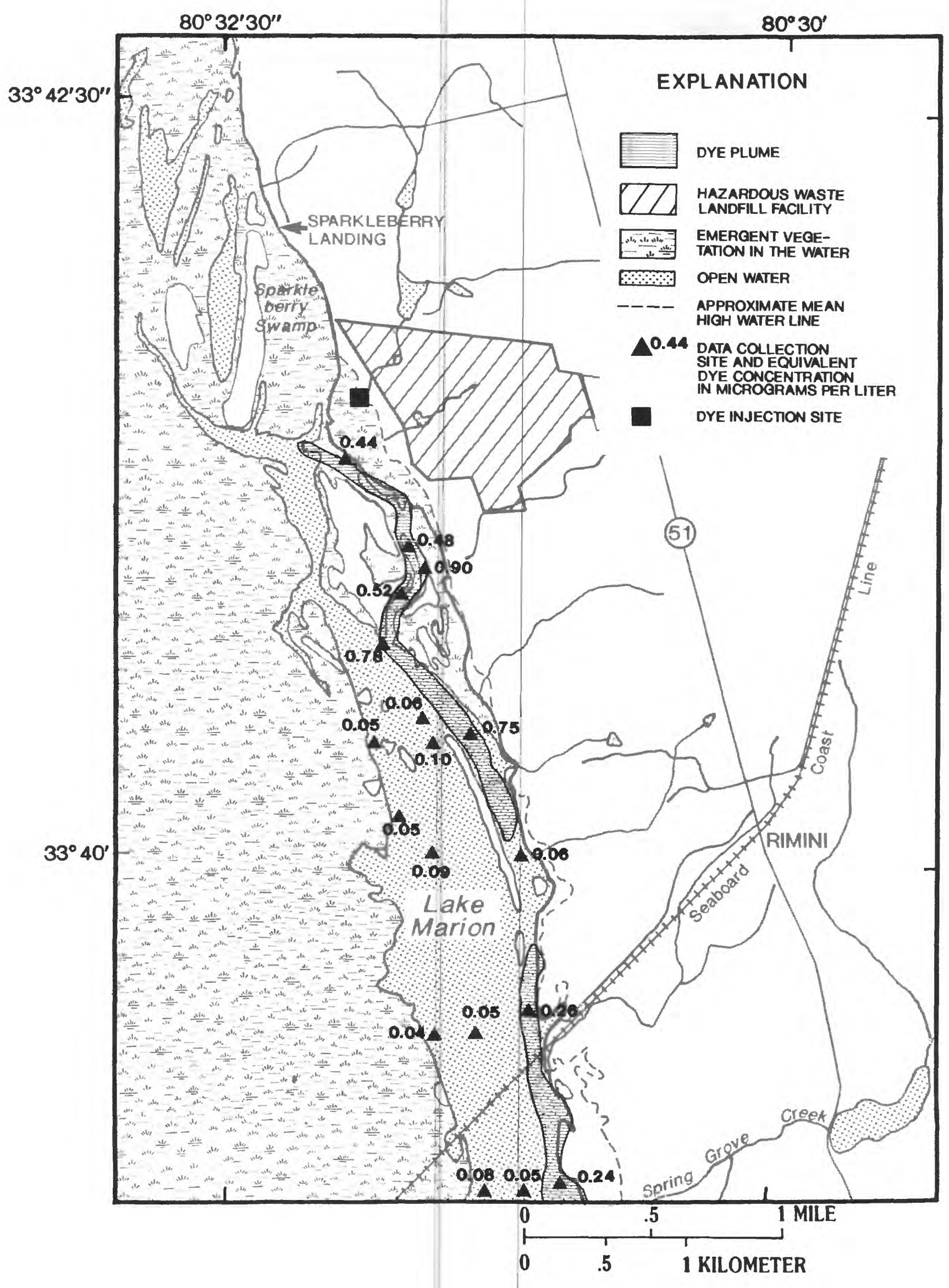

Figure 13.--The extent of dye plume in Lake Marion during low-flow conditions on December 1, 1987, 21 days after dye injection. 


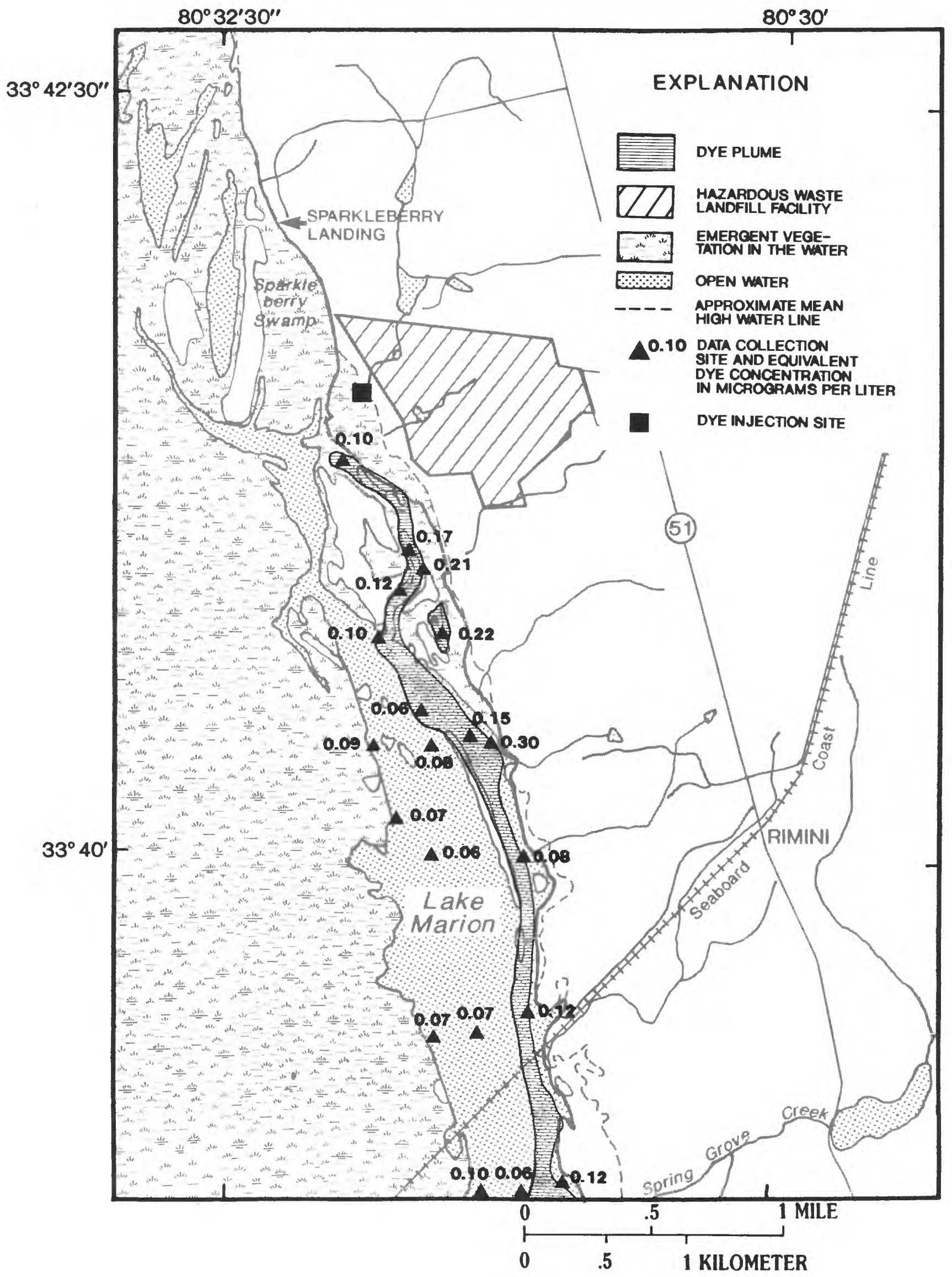

Figure 14.--The extent of dye plume in Lake Marion during low-flow conditions on December $8,1987,28$ days after dye injection. 


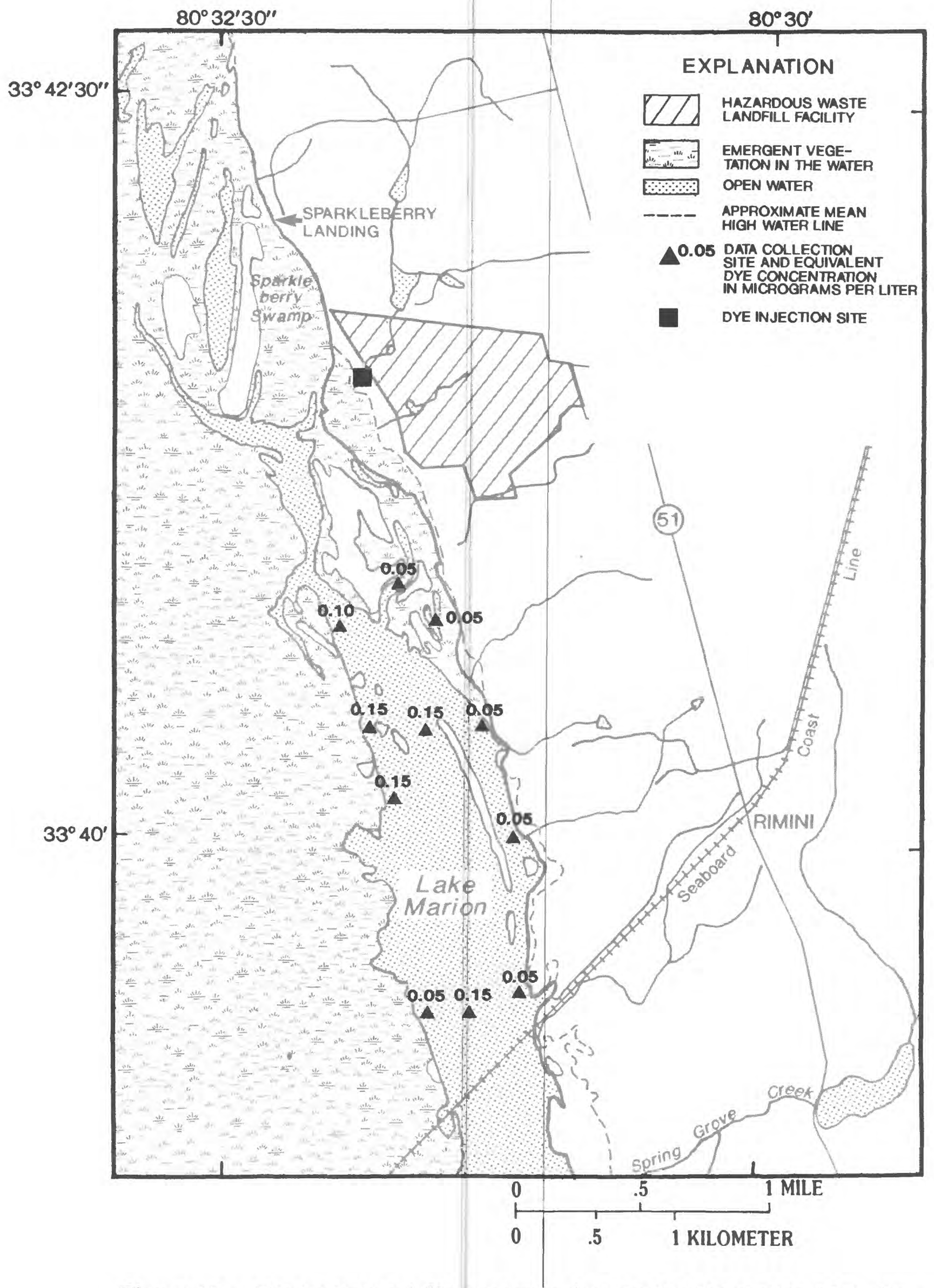

Figure 15.--The background fluorescence in Lake Marion during high-flow conditions on March 30, 1987 prior to dye injection. 


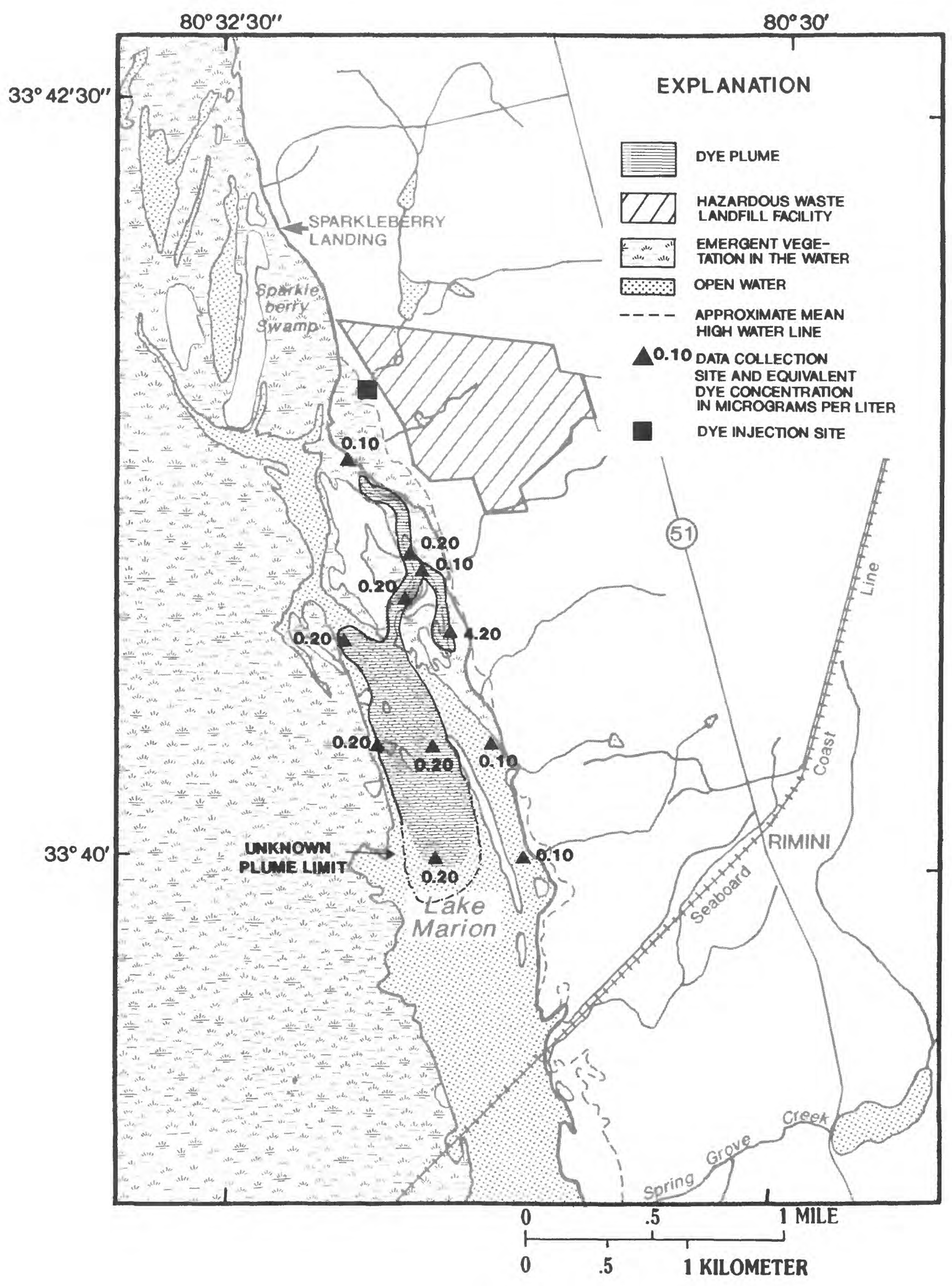

Figure 16.--The extent of dye plume in Lake Marion during high-flow conditions on March $31,1987,0.5$ day after dye injection. 


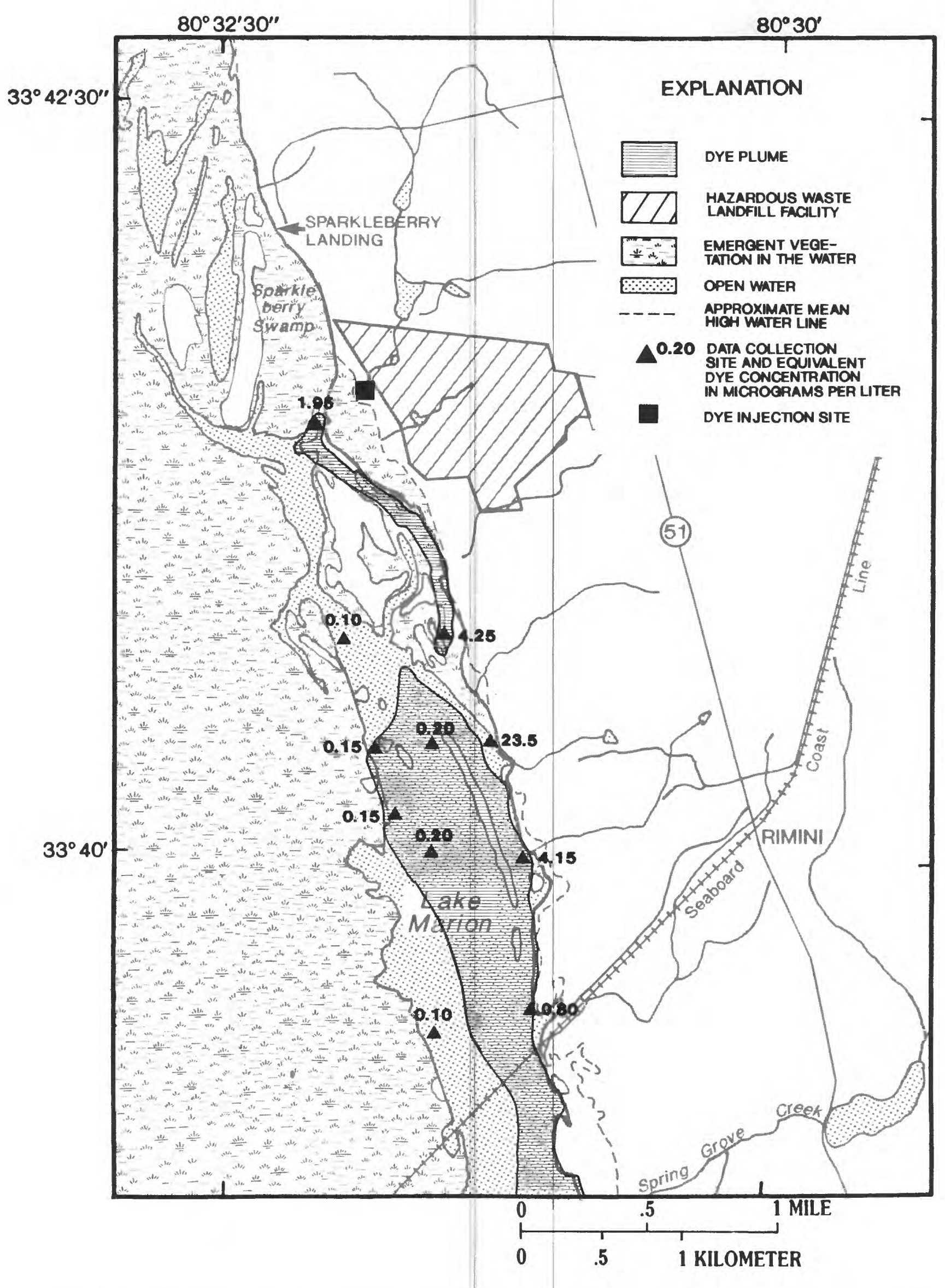

Figure 17.--The extent of dye plume in Lake Marion during high-flow conditions on April 1, 1987, 1 day after dye injection. 


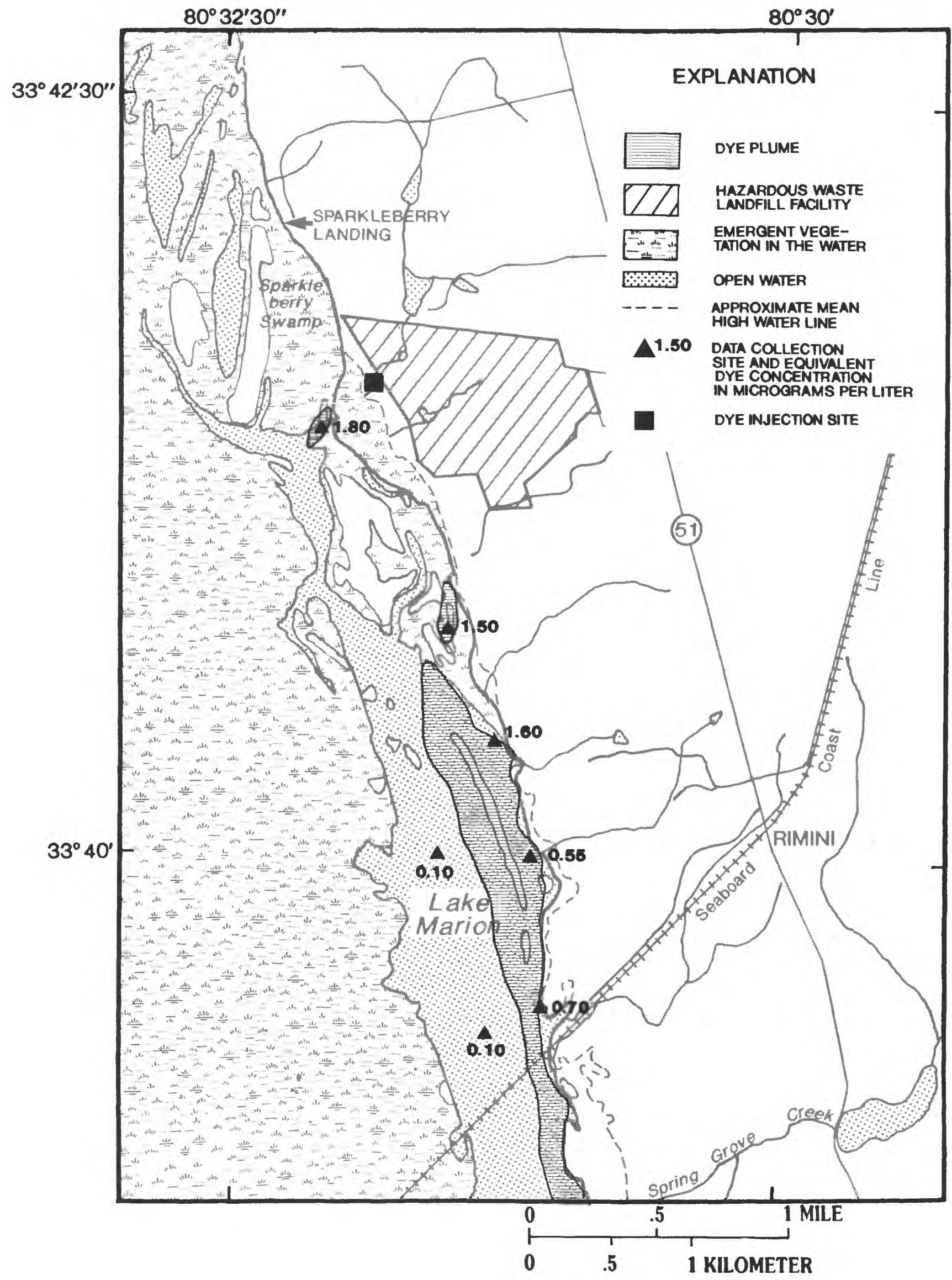

Figure 18.--The extent of dye plume in Lake Marion during high-flow conditions on April 2, 1987, 2 days after dye injection. 


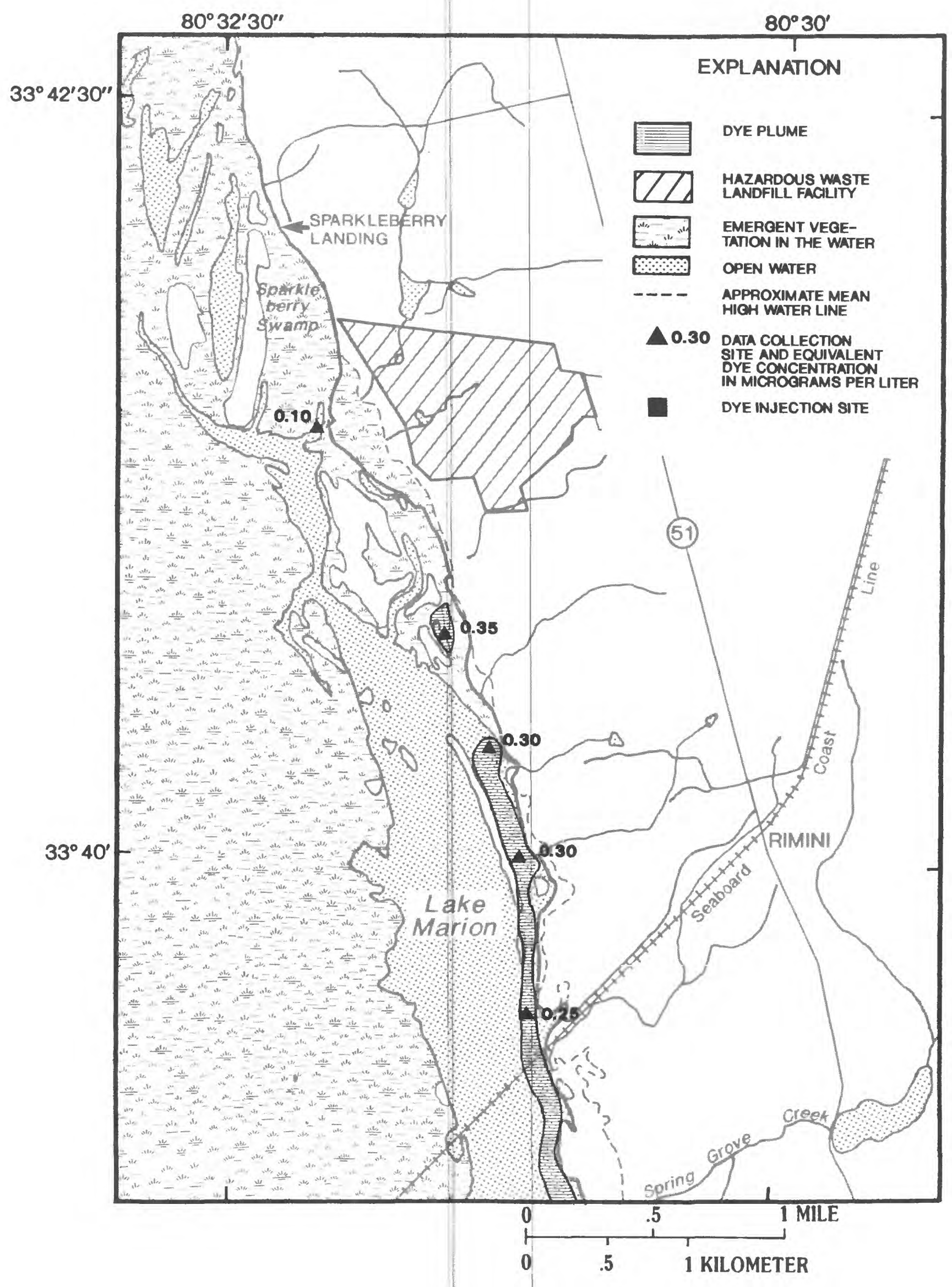

Figure 19.--The extent of dye plume in Lake Marion during high-flow conditions on April 3, 1987, 3 days after dye injection. 
low-flow study was found to be equivalent to that of $0.08 \mu \mathrm{g} /$ (micrograms per liter) dye, with a standard deviation of 0.02 . Mean background fluorescence for the high-flow study was equivalent to $0.10 \mu \mathrm{g} / \mathrm{h}$ of dye, with a standard deviation of 0.04 . At a significance level of 0.05 , all low-flow values equal to $0.10 \mu \mathrm{g} / \mathrm{L}$ or less and high-flow values equal to $0.12 \mu \mathrm{g} / \mathrm{L}$ or less are considered to represent background fluorescence; higher values indicate a measurable concentration of dye.

The low-flow dye tracer study began on November 10, 1987, and the dye plume was monitored through December 8, 1987. Background fluorescence in the lake is shown in figure 5. Fifty pounds of dye were released into Lake Marion at the mouth of the stream draining basin B, about $0.2 \mathrm{mi}$ downstream (south) of stream gaging station 5 (fig. 5). Transport of the dye through the lake at varying increments during a 27-day period is shown in the series of figures 6 through 14. The most significant transport occurred in a southeasterly direction with the dye plume hugging the eastern shore of the lake. A greater degree of transport toward the western side of the lake occurred in the southermost part of the study area. Some of the dye was transported westward from the injection site, but it appears not to have moved much farther than $2,000 \mathrm{ft}$ from the injection site, al though no samples were collected farther north or west to confirm this.

The high-flow dye test began with background measurements on March 30 , 1987. Background fluorescence is shown in figure 15. On the morning of March 31 , fifty pounds of dye were released into the stream at a point immediately downstream of stream-gaging station 5 in basin B (fig. 15). The dye plume was monitored through April 6, 1987.

Transport of the dye through the lake in single-day increments for 4 days is shown in the series of figures 15 through 19 . The concentration of dye in figures 15 through 19 represent the highest value recorded from several measurements made during each day. In some cases the extent of the dye plume was not well defined owing to sparse measurements, as indicated by dashed boundary lines in the figures. As in the low-flow study, the most significant transport of the dye through the lake was to the southeast; however, distribution of the dye was much quicker under high-flow conditions. Water with the highest concentrations of dye was found to flow along the eastern shore of the lake, as had occurred in the low-flow study, with small amounts of dispersion toward the west. Higher dye concentrations were measured at the northermost station than had been detected during the low-flow study. Although transport of the dye north and west of this station did not appear to be significant, no measurements were made farther north or west in the lake to confirm this observation.

Patterns of water transport in Lake Marion as a whole were investigated in a separate study made in 1983 by the U.S. Geological Survey in cooperation with the South Carolina Department of Health and Enviromental Control. 


\section{STATION LOCATIONS AND DESCRIPTIONS}

The remainder of this report presents measurements and analyses of samples collected from seven permanent stations as shown on figure 2. Stations 1 and 2 are in Lake Marion and were used for collection of water-quality, sediment-quality, and biological samples only. Stations 3, 4,5 , and 6 were located on streams, and were the sites for collection of streamflow records as well as water-quality, sediment-quality, and biological data. Station 7 was used for collection of rainfall data only. General site descriptions of the stations follow.

\section{Station 1}

Station 1 is located in Sparkleberry Swamp, part of the wetlands that make up the upper reaches of Lake Marion, approximately $900 \mathrm{ft}$ south of the mouth of the small stream that drains area C. The water at this station is probably derived from upstream tributaries along the eastern banks of the Wateree and Santee Rivers, with some contribution from upstream ground-water discharge. Water in Sparkleberry Swamp flows to the southeast at a speed that ranges from barely perceptible during low flow to more than a foot per second during high flow. As this station is located approximately $4,200 \mathrm{ft}$ upstream of the nearest point of discharge from drainage areas that include parts of the landfill site, it represents background lake conditions unaffected by runoff from the landfill. Although this was not conclusively demonstrated by the dye tracer study presented above, visual observations of flow in the area of station 1 indicate that station 1 is up-gradient of any stream discharges from the landfill.

\section{Station 2}

Station 2 is located in Lake Marion approximately 3,400 $\mathrm{ft}$ south of the mouth of the stream that drains basin $A$ and about $200 \mathrm{ft}$ from shore. Dye tracer studies described above indicate that this site may be influenced by runoff from the landfill site. Station 2 is therefore in the part of the lake that is within the potential influence of the landfill operations.

\section{Station 3}

Station 3 is located approximately $1 \mathrm{mile}$ northwest of the center of the landfill site on a small unnamed stream in basin C. The stream discharges to Sparkleberry Swamp. The basin is northwest of the landfill and does not include any part of the landfill site. The basin is 90 percent forested with the remaining part cleared for agriculture. A dirt road traverses the basin. This station represents background stream conditions relative to streams that drain parts of the landfill site. 


\section{Station 4}

Station 4 is located on a small unnamed stream approximately $2,600 \mathrm{ft}$ northwest of the center of the landfill site, immediately downstream of a 9.2-acre pond in basin D. The stream discharges to Sparkleberry Swamp (Lake Marion) 2,000 ft downstream of the station. Upstream of station 4 the basin does not include any substantial part of the landfill site. The drainage basin is 40 percent forested and the remainder is cleared for agriculture and residential use. Several dirt and paved roads traverse the basin. This station represents background conditions relative to areas within the drainage area of the landfill site.

\section{Station 5}

Station 5 is located approximately $1,200 \mathrm{ft}$ downstream of station 4 on the same unnamed stream. The stream discharges to Sparkleberry Swamp (Lake Marion) about $600 \mathrm{ft}$ downstream of station 5 . About 90 percent of the drainage area (basin $B$ ) between station 4 and station 5 lies in the northwestern corner of the landfill, and the stream flows through a sedimentation pond on the landfill facility. The stream also receives drainage immediately above the sedimentation pond from a French drain. ( $f$ ig. 3 ) that is installed in the water-table aquifer along part of the northern boundary of the landfill property. This French drain diverts shallow ground water from parts of drainage basins $A$ and $B$ to the stream. The drainage basin is 20-percent forested and the remainder is cleared for agriculture and the landfill operation. This station represents a stream segment that may be influenced by the landfill operation.

\section{Station 6}

Station 6 is located approximately $1,200 \mathrm{ft}$ west of the center of the landfill on an unnamed stream immediately downstream of a sedimentation pond that is situated on the landfill site. The stream discharges to Sparkleberry Swamp (Lake Marion) about $500 \mathrm{ft}$ downstream of station 6. The drainage basin of the stream above station 6 (basin A) includes 65 percent of the landfill site area. The stream also receives discharge at the sedimentation pond from a French drain that is installed in the water-table aquifer in the southern part of the landfill. The French drain is designed to divert shallow ground water away from one of the waste burial cells. Station 6 represents a stream significantly within the influence of the landfill operation. Except for some small stands of trees and brush, mostly along stream banks, the basin is entirely cleared for the landfill. The topography of the landfill site has been changed during the monitoring program by construction and landfilling operations; therefore, the character of the basin has seen considerable alteration.

\section{Station 7}

Station 7 is located within the landfill site on a topographically high area. This site was used only for collecting rainfall data. 


\section{STREAMFLOW AND RAINFALL}

\section{Methods}

Records of streamflow are derived from automatic recording of stream stage at 30-minute intervals throughout the study period, and a series of manual measurements of stream discharge at various rates of flow. A rating curve that describes the stage-discharge relation is constructed from the measurements, and is used to calculate a continuous streamflow record from the stage record. The streams in the study area are not affected by variable backwater; therefore, a conventional stage-dishcarge relation is sufficient for calculating streamflow. Rainfall frequency and volume measurements are made automatically with a permanently installed recording rain gage. The methods used for collecting and analyzing streamflow and rainfall data in this study are briefly discussed below. More comprehensive treatments of the methods are given by Buchanan and Somers, 1968 and 1.969; Carter and Davidian, 1968; Kennedy, 1983; and Kennedy, 1984.

\section{Stage Measurements}

Stream stage or gage height (height of the water surface relativę to a chosen datum) data are collected automatically, using a Fisher-Porter digital recorder that records the level of a float on the water surface at 30-minute intervals. The float is contained within a permanently installed stilling well, which is hydraulically connected to the stream through a small perforated pipe. The recording gage is periodically compared to a staff gage (a calibrated post), installed in the stream adjacent to the recording gage, to assure its accuracy. In addition, elevations of the recording gage and staff gage are checked with reference to several points around the station for assurance of gage stability. The datum for elevations is arbitrary and different for each site.

Stream stage is a function of the streamflow and the geometry and slope of the stream channel. The physical elements or combination of elements that determine the stage-discharge relation is known as the control, a restrictive section of the stream channel downstream of the gage that may be natural or artificial. Artificial controls were constructed for three of the gaging stations. Specific details about the controls are given as part of detailed gaging station descriptions in the appendix.

${ }^{1}$ The use of brand names in this report is for the purpose of identification only and does not constitute endorsement by the U.S. Geological Survey. 


\section{Stream-Discharge Measurements}

Conventional streamflow data are collected by making a series of manual measurements of depth and flow velocities at intervals along the stream cross section. Flow velocities are measured with a handheld current meter (Price meter) with a rotor that turns at a rate proportional to the velocity of the water. Each velocity measurement gives the average velocity through a partial area of the stream cross section; the size of the partial area depends on the spacing interval between the individual measurements and channel depth at each measuring point. Streamflow is the summation of the products of the partial areas of the stream cross section and their respective average velocities.

\section{Stage-Discharge Relation}

A rating curve that describes the stage-discharge relation is developed for each gaging station by plotting streamflow versus stage and interpolating a best-fit curve through the points. To the extent possible, measurements are made over the full range of flows for the best definition of the stage-discharge relation. The rating curve generally can be extrapolated down to the point of zero flow (PZF), which corresponds to the point of lowest elevation on the station control or the point of highest elevation in the thalweg of a channel control reach. Where sections of rating curves lack data for accurate representation of the stage-discharge relation (usually at high streamflows), approximations can be calculated on the basis of stream-channel geometry and the physics of open-channel flow of water. Details regarding the individual ratings will be discussed in a later section.

\section{Rainfall Measurements}

The volume and frequency of rainfall were measured in the study area using a recording rain gage. A funnel at the top of the gage feeds rainfall to a uniformly sized pipe. The height of the water in the pipe is monitored and recorded at 30-minute intervals with a float attached to a Fisher-Porter digital recorder. The rainfall, in inches, equals the product of the height of the water in the pipe and the inside cross-sectional area of the pipe divided by the cross sectional area of the top of the funnel.

\section{Streanflow Records}

The following records of streamflow includes 1) a rating curve that reflects the relation between stage and discharge that prevailed during the data collection period at each station; 2) a table of daily mean streamflows; monthly maximum, minimum, and mean flows; and the annual maximum, minimum, and mean flows, all in cubic feet per second at each station; and 3) comments on the data and computations. Detailed descriptions of each gaging station are given in the appendix. The accuracy of the records may be influenced by the stability of the stage-discharge relation, the accuracy of stage observations, the accuracy of discharge 
measurements, and other factors. The degree of accuracy of the streamflow records is indicated in the station descriptions either as "excellent" (95 percent of the daily discharges are within 5 percent of their actual values), "good" (within 10 percent), "fair" (within 15 percent), or "poor" (less than "fair" accuracy). Values of streamflow in this report are given to the nearest hundredth of a cubic foot per second for flows less than 1.0 $\mathrm{ft}^{3} / \mathrm{s}$, and to the nearest tenth for flows greater than or equal to 1.0 $\mathrm{ft}^{3} / \mathrm{s}$.

\section{Station 3}

The stage-discharge rating curve for station 3 (fig. 20) graphically shows the relation between stage and streamflow prevailing during the study period, on rectangular and logarithmic scales. The rating derived from the relation plotted in figure 20 was used to compute streamflow values for station 3.

Mean daily streamflows and monthly maximum, minimum, and mean flows for station 3 are given in table 1 .

Manual discharge measurements were not made at station 3 for stages higher than $0.86 \mathrm{ft}$, although the highest stage recorded during the study period was $1.56 \mathrm{ft}$. The stage-discharge rating curve was estimated for stages above $0.86 \mathrm{ft}$ by an indirect method of determining flow based on the geometry of the stream channel and the station control, a V-notch weir on the upstream end of a culvert (fig. 20). Critical depth and flow were computed using procedures described for box culverts (Bodhaine, 1968), as well as for weirs (Hulsing, 1967), resulting in similar estimates. The gage malfunctioned November 26-28, 1988, and flows for these days were estimated on the basis of the trend of the hydrograph. Based on the computed curve for high flows, the peak instantaneous flow during the study period was 6.4 $\mathrm{ft}^{3} / \mathrm{s}$ on July 27 , 1988. Minimum instantaneous flow was $0.02 \mathrm{ft}^{3} / \mathrm{s}$, recorded on several days in June and July 1988. The maximum monthly mean flow was $0.11 \mathrm{ft}^{3} / \mathrm{s}$ in January 1988 , and the minimum monthly mean flow was $0.05 \mathrm{ft}^{3} / \mathrm{s}$ in November 1987 . The annual mean flow from January 1 , to December 31,1988 , was $0.08 \mathrm{ft}^{3} / \mathrm{s}$. Baseflow in the stream ranged between 0.02 and $0.10 \mathrm{ft}^{3} / \mathrm{s}\left[0.30\right.$ to $\left.1.5\left(\mathrm{ft}^{3} / \mathrm{s}\right) / \mathrm{mi}^{2}\right]$.

\section{Station 4}

The stage-discharge rating curves for station 4 (fig. 2l) graphically show the relation between stage and streamflow for two periods, between September 22, 1987 and July 15, 1988, and between July 15, 1988, and January 5, 1989. The rating tables derived from the relations plotted in fig. 21 were used to compute flow values for station 4. Mean daily flows and monthly maximum, minimum, and mean flows for station 4 are given in table 2 . 


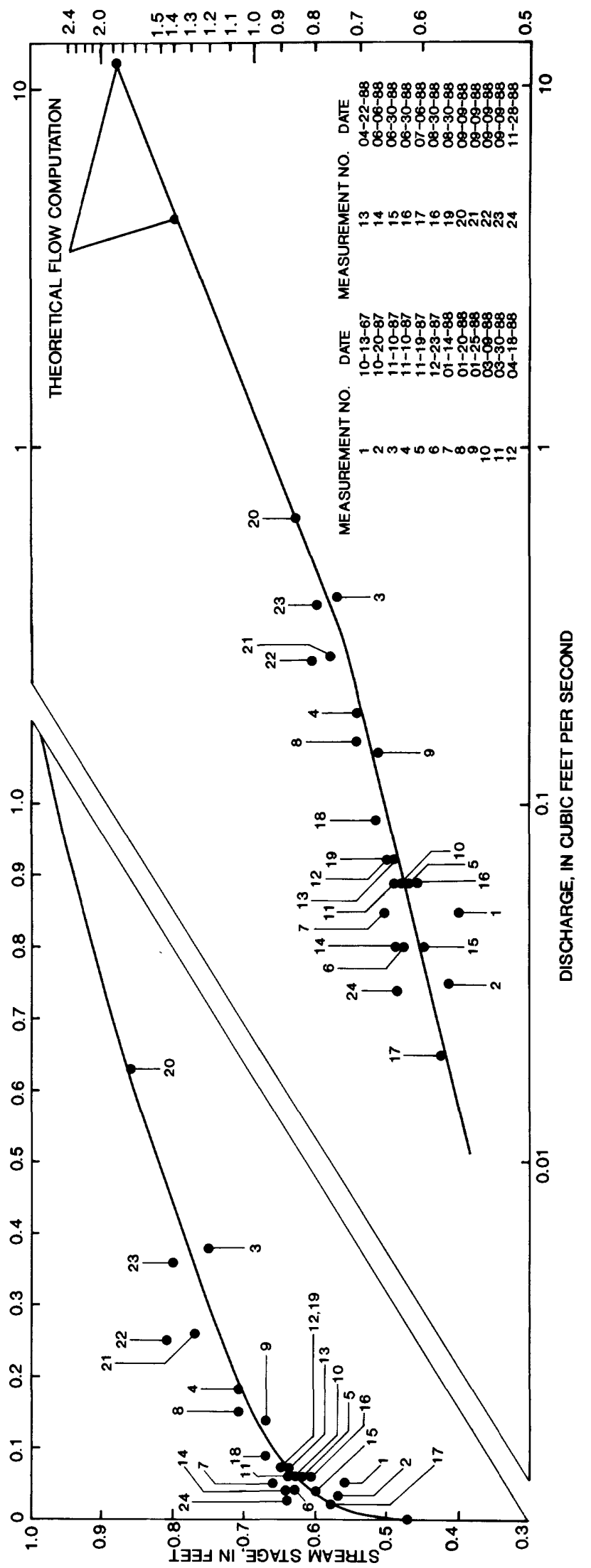

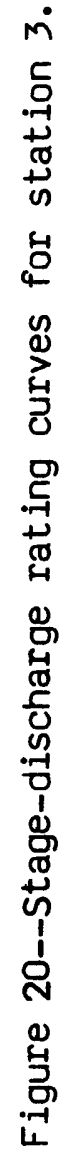




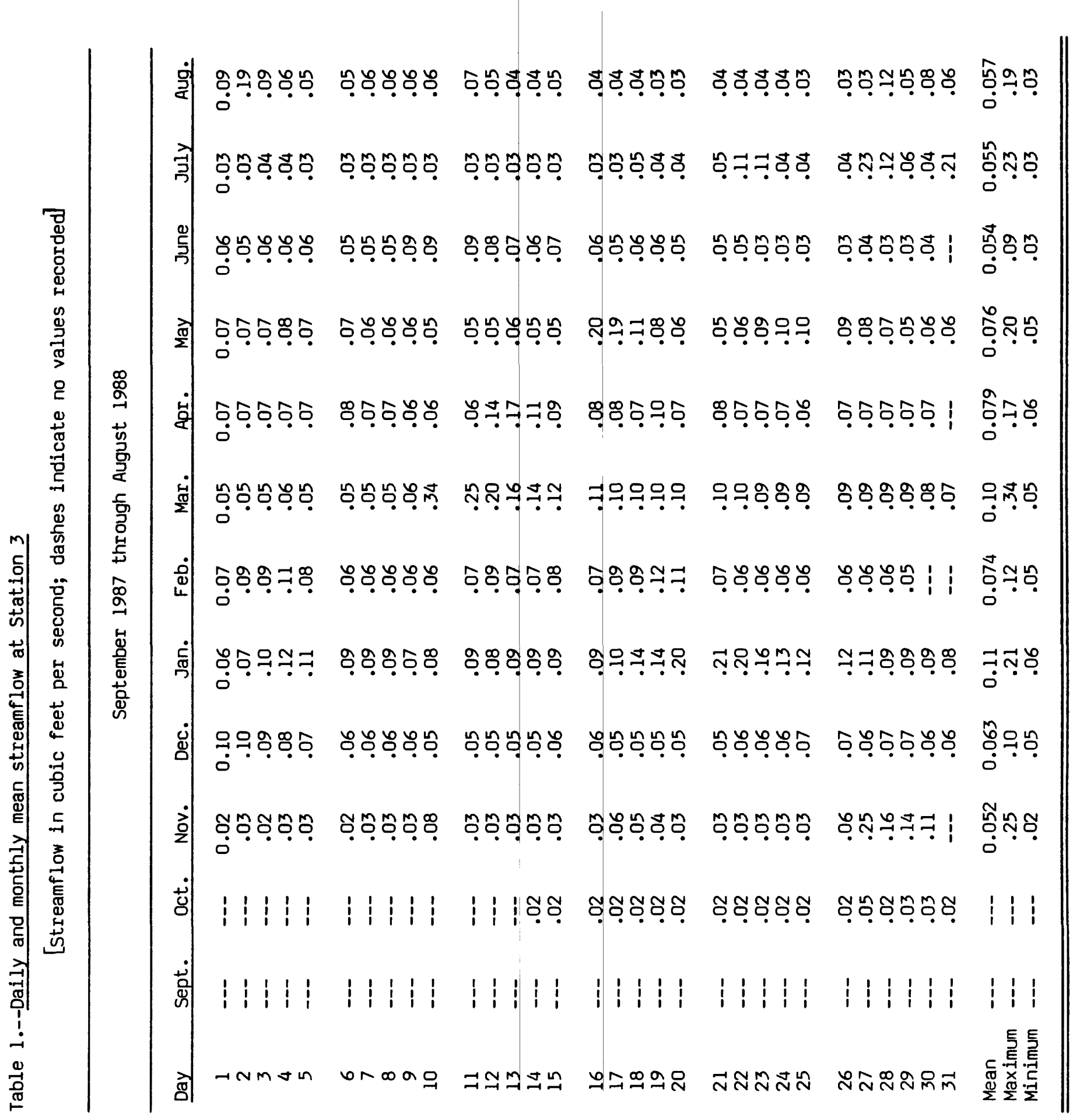




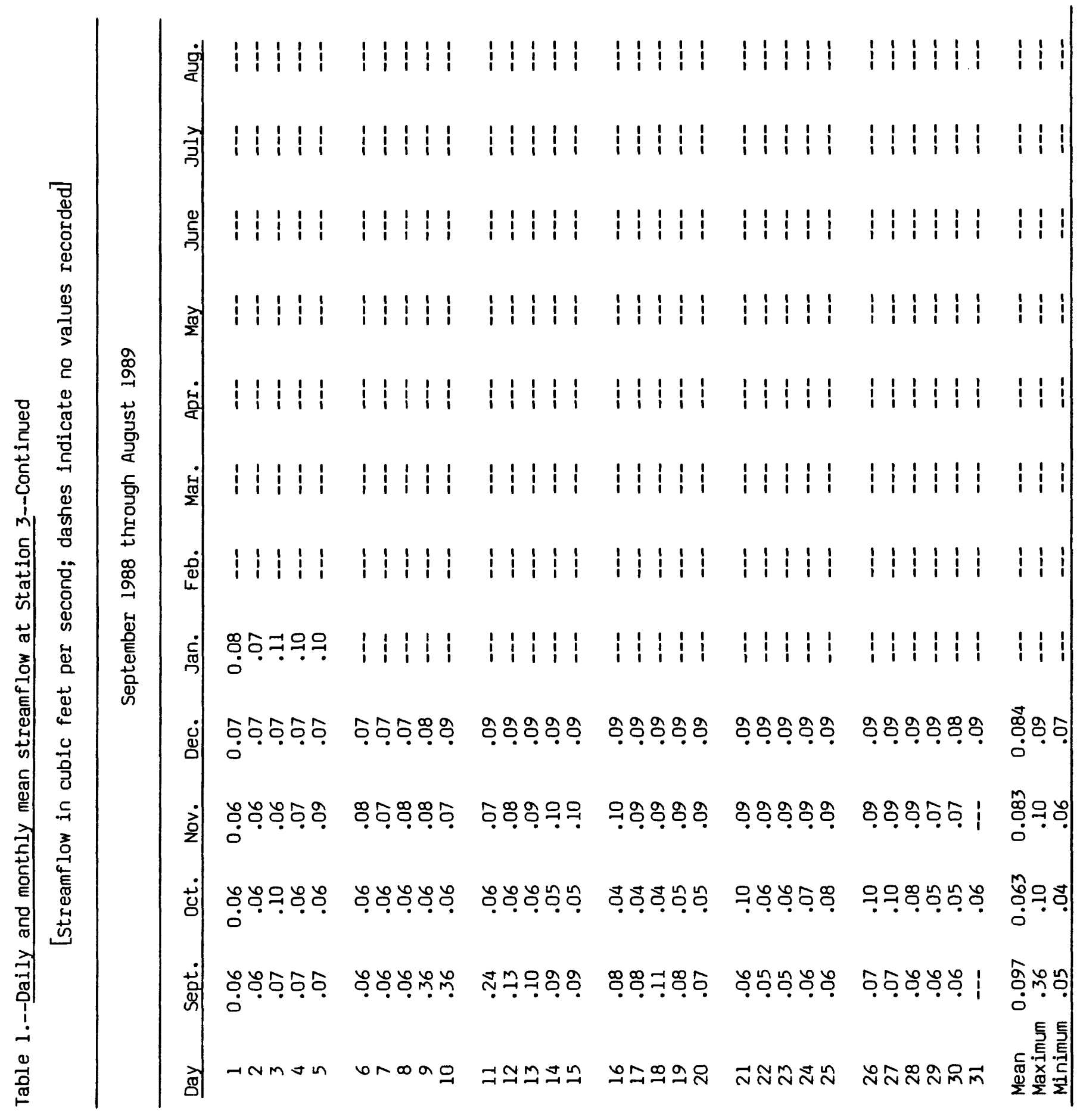




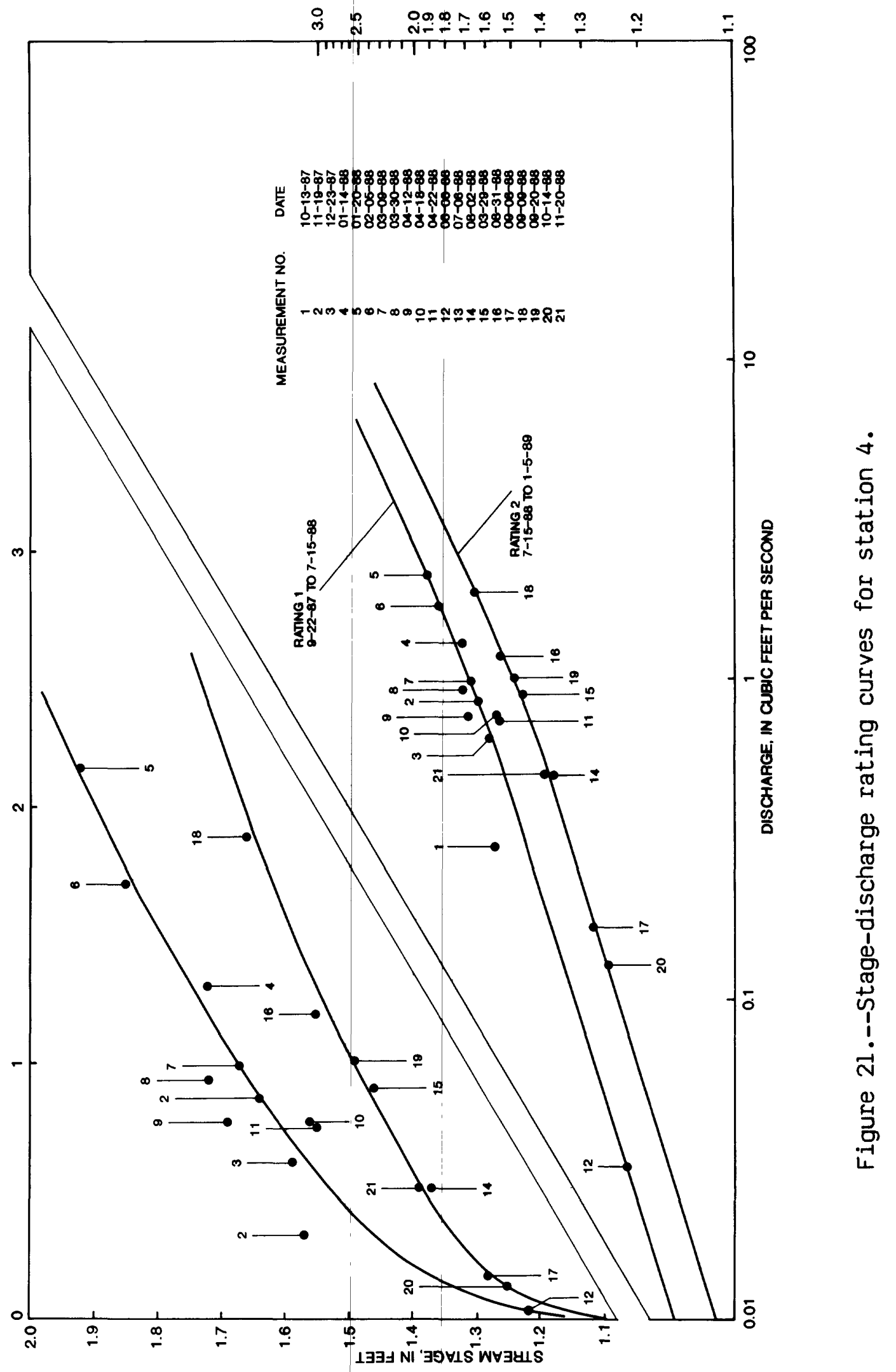




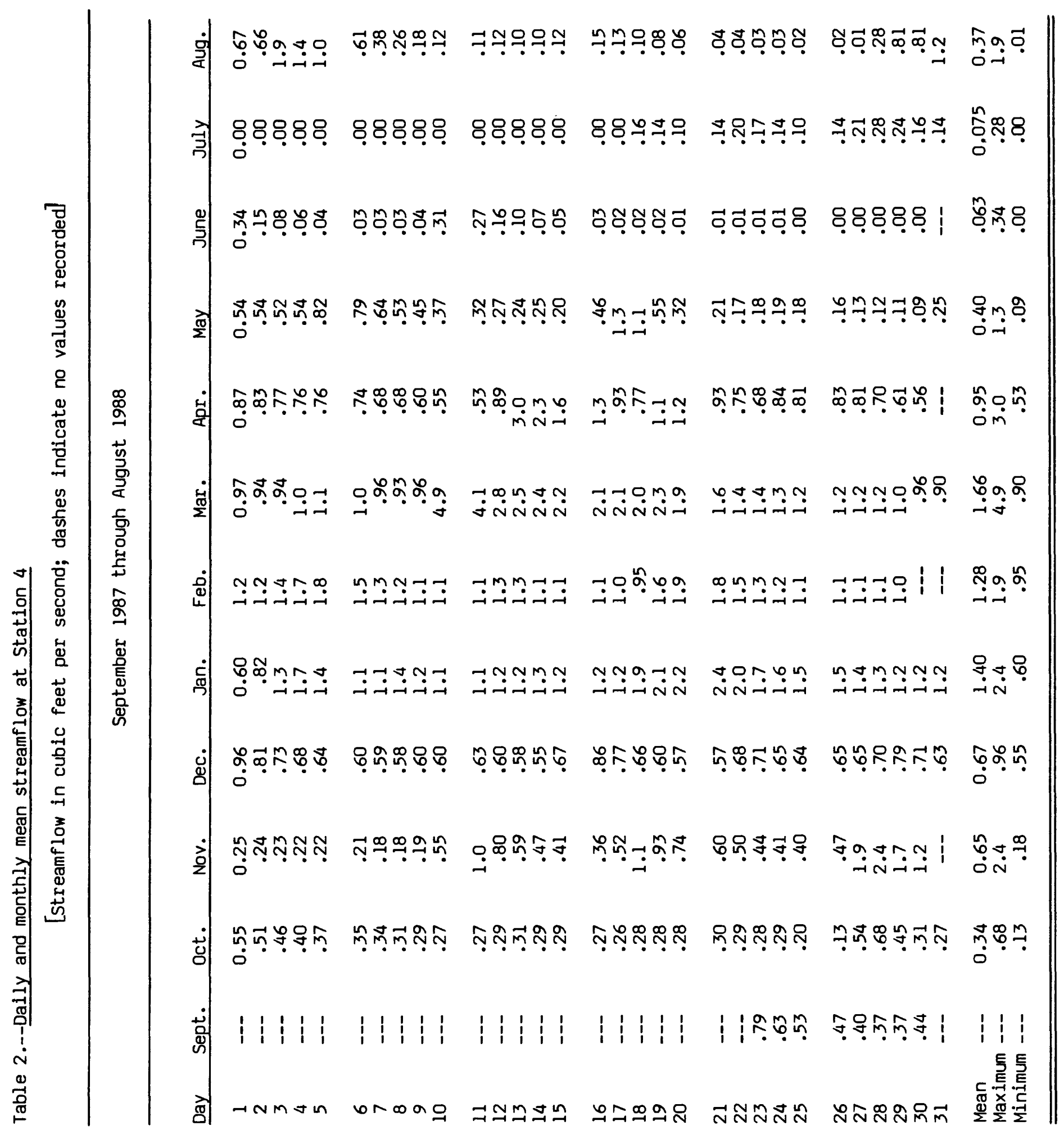




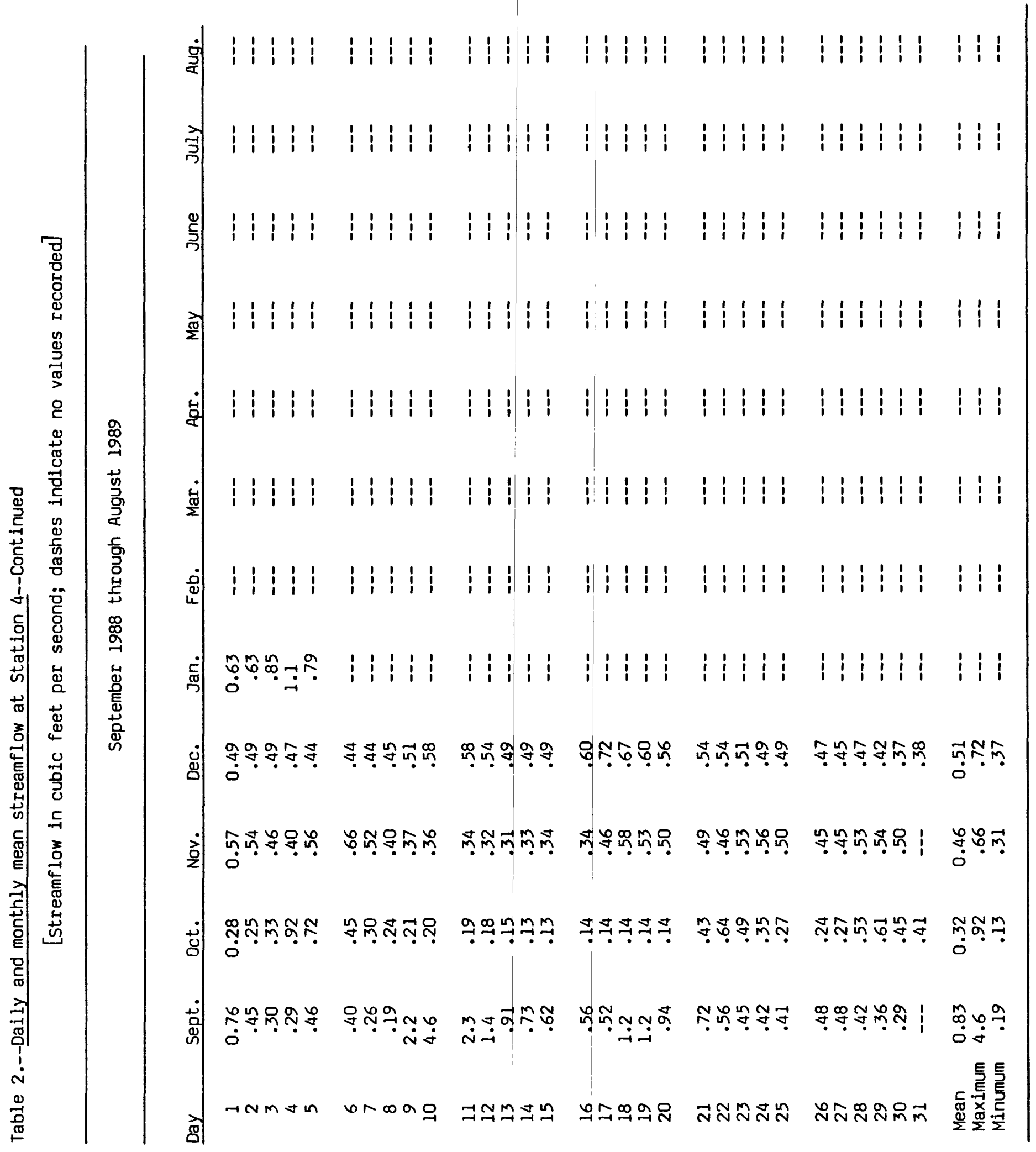


The stage-discharge rating at station 4 changed abruptly on July 15 , 1988 (fig. 2l). Prior to this date a log was observed to be partially obstructing the intake structure to the spillway that controls flow from the pond to the stream. Movement of the log probably was responsible for the change in rating. The intake is a highly corroded cylindrical steel structure, and part of it may have caved in, also affecting the rating. Two separate ratings were determined, one for the period prior to the change, and the other for the period after the change.

No stage records were collected at Station 4 from July 18 to July 27 , 1988 , because of a recorder malfunction. Mean daily flows for this period were estimated on the basis of hydrograph comparison of station 4 with station 5, located $1,200 \mathrm{ft}$ downstream.

Minor shift adjustments have been applied to the calculated streamflow data for station 4 as described by Kennedy (1983), to account for any significant deviations of the rating curves from measured flow values.

The peak instantaneous flow recorded at station 4 during the study period was $6.3 \mathrm{ft}^{3} / \mathrm{s}$ on March 10, 1988. Minimum instantaneous flow was 0.00 $\mathrm{ft}^{3} / \mathrm{s}$ recorded on several days in June and July. The maximum monthly mean flow was $1.7 \mathrm{ft}^{3} / \mathrm{s}$ in March 1988, and the minimum monthly mean flow was $0.063 \mathrm{ft}^{3} / \mathrm{s}$ in June 1988. The annual mean flow for the period from January 1 to December 31, 1988, was $0.69 \mathrm{ft}^{3} / \mathrm{s}$. Baseflow in the stream ranged from 0.00 to $1.0 \mathrm{ft}^{3} / \mathrm{s}\left[0.00\right.$ to $\left.0.66\left(\mathrm{ft}^{3} / \mathrm{s}\right) / \mathrm{m}^{2}\right]$.

\section{Station 5}

The stage-discharge rating curve for station 5 (fig. 22) graphically shows the relation between stage and flow prevailing during the study period. The rating table derived from the relation plotted in figure 22 was used to compute flow values for station 5. Mean daily flows and monthly maximum, minimum, and mean flows for station 5 are given in table 3 .

The stage-discharge rating at station 5 began changing gradually sometime between July 19 and August 29,1988 , and continued to do so at least until November 28, 1988, owing to the highly unstable nature of the sandy streambed (fig. 22). Large accumulations of sediment were observed in the stream in the vicinity of the gage. Streamflow during the period of the changing rating was estimated by applying a shift correction to the rating curve, which is based on the assumption that the rating curve retains its shape and simply moves higher on the stage axis of the rating curve plot as indicated by the flow measurements. Rating shifts after the final discharge measurement made on November 28,1988 , are unknown, but approximate flows between November 28, 1988, and January 5, 1989, were calculated using the same shift adjustment applied to the rating curve on November 28,1988 . No rainfall of sufficient intensity to scour or deposit sediments in the stream channel occurred during this time period, suggesting that this is a good estimate. 


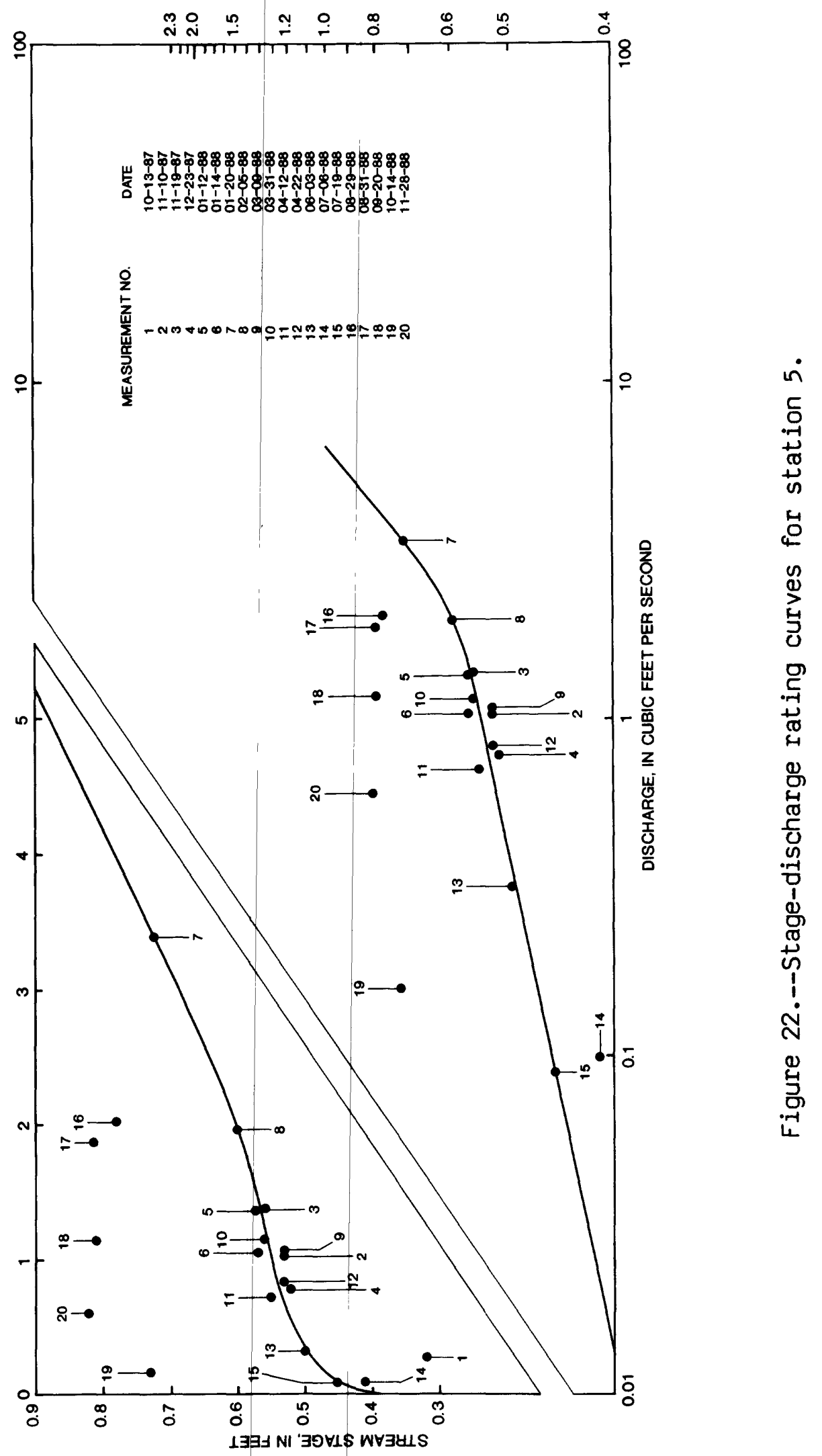




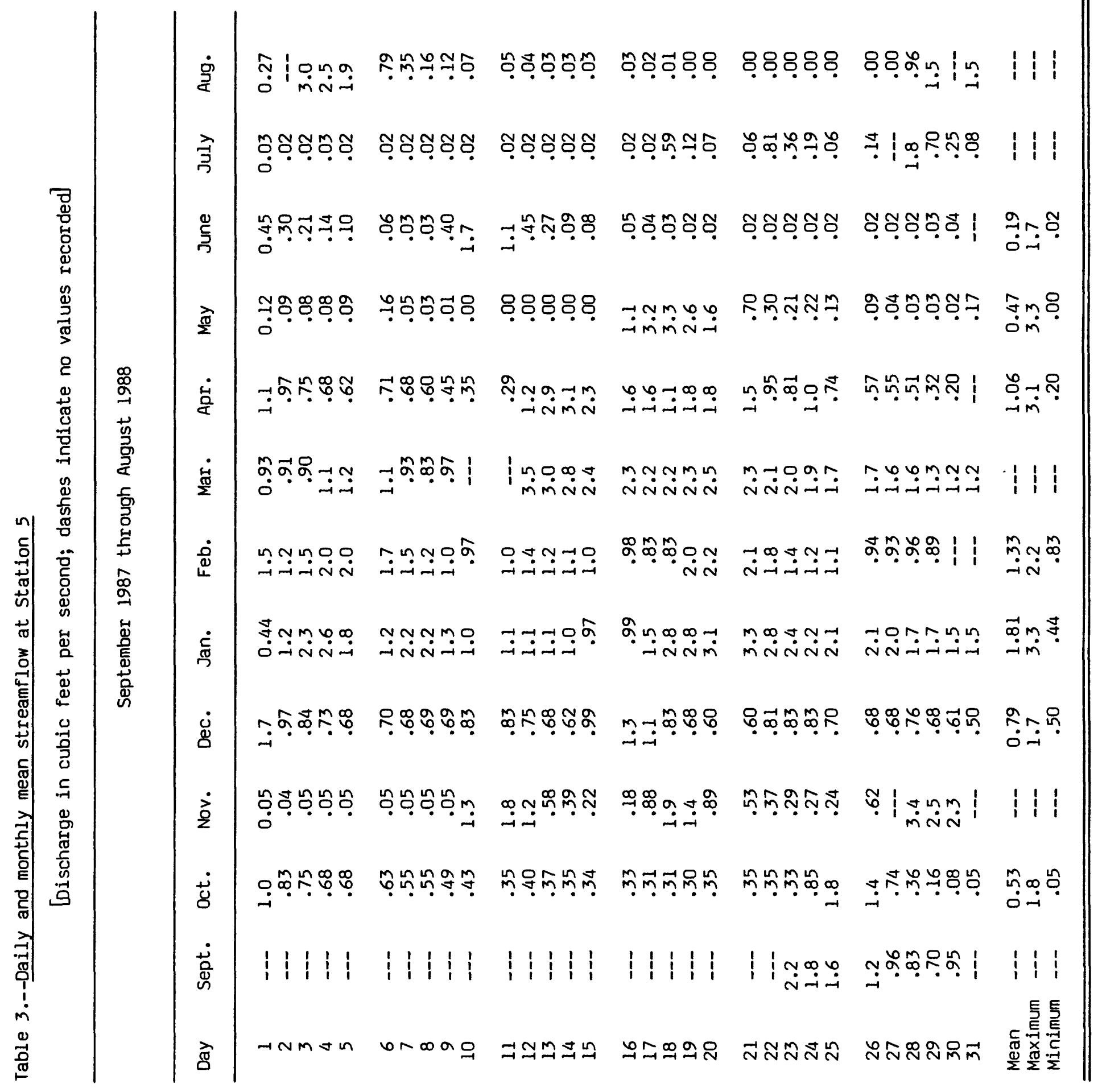




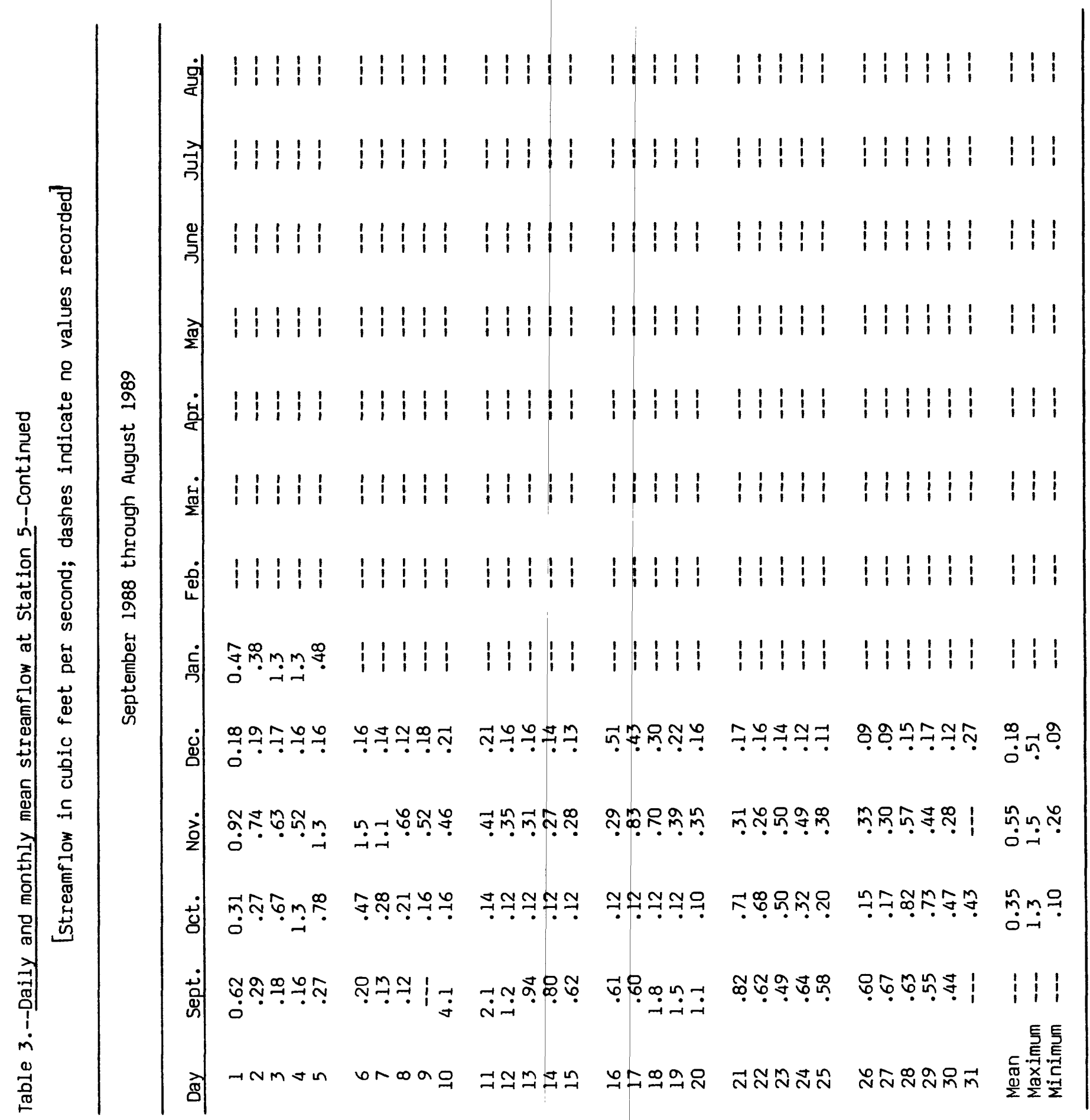


Hydraulic connection between the stream and the gage at station 5 was noticeably slow owing to a plugged intake on June 2 and 3 and July 29, 1988. Mean daily flows for these dates were estimated on the basis of hydrograph comparison with station 4, located 1,200 ft upstream.

Manual discharge measurements were not made at station 5 for stages higher than $0.82 \mathrm{ft}$, although recorded stages were as high as $1.55 \mathrm{ft}$. Because flow is controlled by the natural stream channel, no accurate estimates for the stage-discharge relation at high flow could be calculated using indirect methods; therefore, the maximum instantaneous flow at station 5 is unknown, and no daily mean flow values are reported in table 3 for days when the stage rose substantially above $0.82 \mathrm{ft}$, which includes November 27 , 1987, March 10 and 11, 1988, July 27, 1988, August 2, 1988, August 31, 1988, and September 9, 1988. Additionally, no monthly mean flows are reported for these months, and no annual mean flow is reported for station 5 . The minimum instantaneous flow at station 5 was $0.00 \mathrm{ft}^{3} / \mathrm{s}$ on several days in May and August.

Flow measured at station 5 is a function of the entire drainage area upstream of station 5, including the portion upstream of station 4 ( fig. 3 ). Baseflow ranged from 0.00 to $0.95 \mathrm{ft}^{3} / \mathrm{s}\left[0.00\right.$ to $\left.0.30\left(\mathrm{ft}^{3} / \mathrm{s}\right) / \mathrm{mi}^{2}\right]$.

\section{Station 6}

The stage-discharge rating curve for Station 6 (fig. 23) graphically shows the relation between stage and streamflow prevailing during the study period. The rating table derived from the relation plotted in figure 23 was used to compute streamflow values for station 6 . Mean daily flows and monthly maximum, minimum, and mean flows for station 6 are given in table 4 .

Streamflow at station 6 was affected substantially by earth-moving and other operations in the landfill facility located directly upstream. Siltation of the culvert and stream channel near the gage was a constant problem requiring periodic removal of sediment from around the gage intake. Additionally, withdrawals of water from the siltation pond upstream of the gage, for use on the landfill site, resulted in periods of very low flow, and occasionally no flow, at the gaging station. The stream may also receive excess water from a ground-water production well used at the facility. The peak instantaneous flow during the study period was $9.8 \mathrm{ft}^{3} / \mathrm{s}$ on March 10, 1988, and the minimum instantaneous flow was $0.00 \mathrm{ft}^{3} / \mathrm{s}$ recorded on several days. The maximum monthly mean flow was $0.79 \mathrm{ft}^{3} / \mathrm{s}$ in January 1988, and the minimum monthly mean flow was $0.12 \mathrm{ft}^{3} / \mathrm{s}$ in June 1988 . The annual mean flow during the period from January 1 to December 31,1988 , was $0.41 \mathrm{ft}^{3} / \mathrm{s}$.

Natural baseflow could not be estimated for station 6 owing to changes in the natural configuration of the drainage area and stream channel. A sedimentation pond, constructed upstream of the gage (fig. 2) attenuates flood peaks. The stream between the pond and the gage flows through a culvert that blocks ground-water discharge to the stream. These factors, along with water withdrawals from the pond, render the streamflow data of little value for determining the contribution to streamflow by ground-water discharge. 


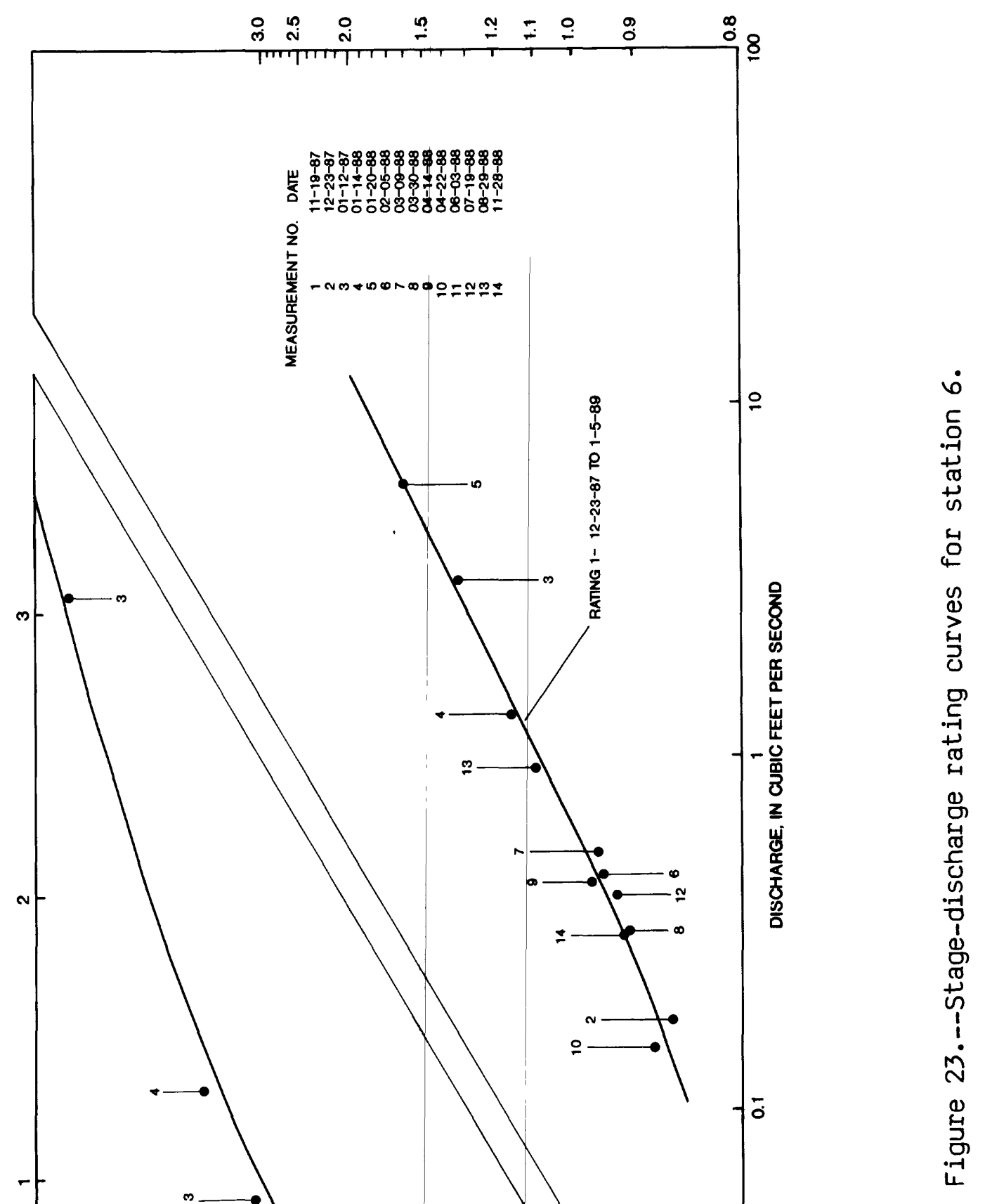




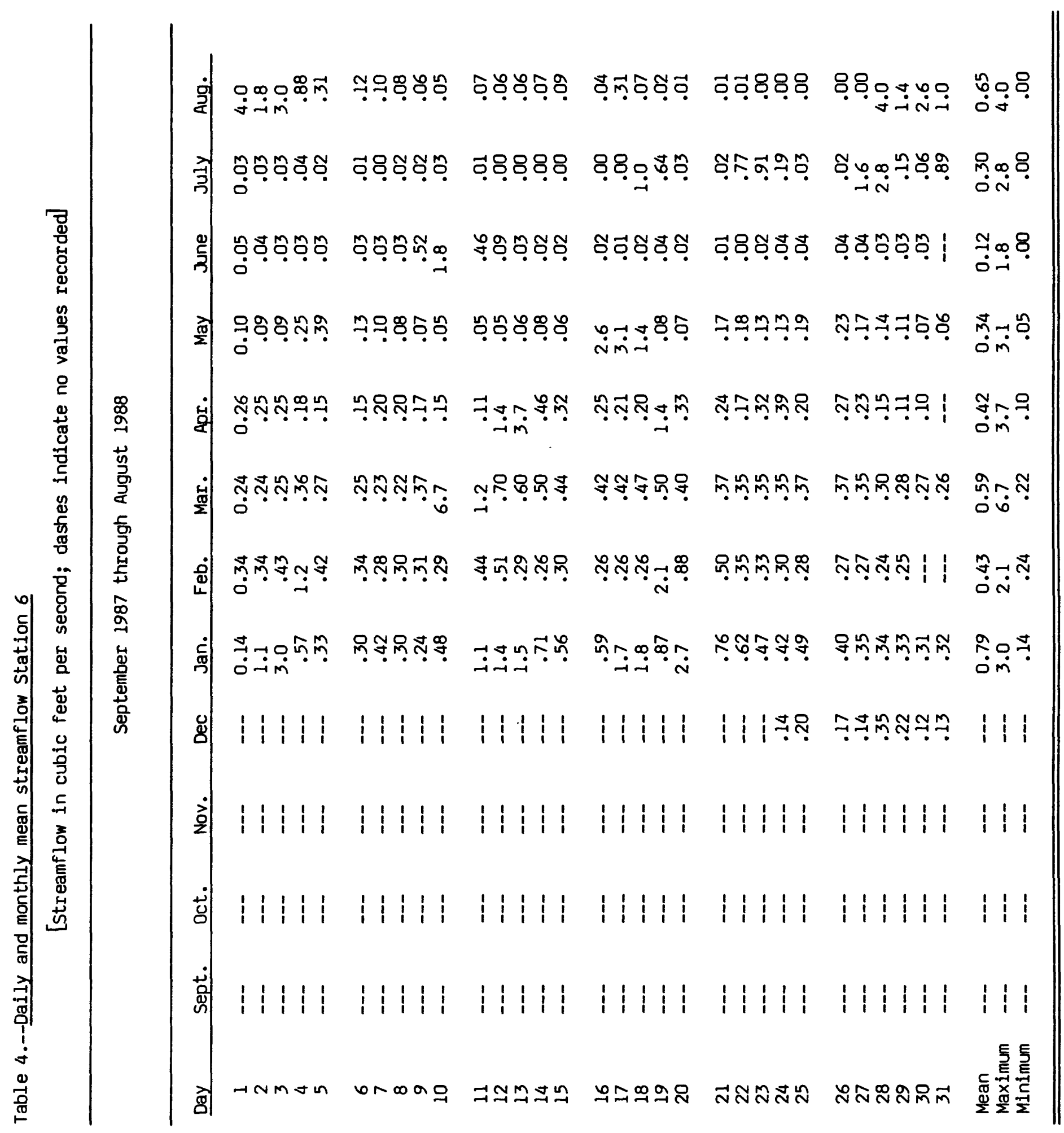




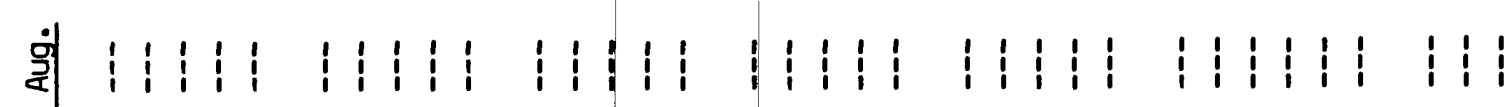

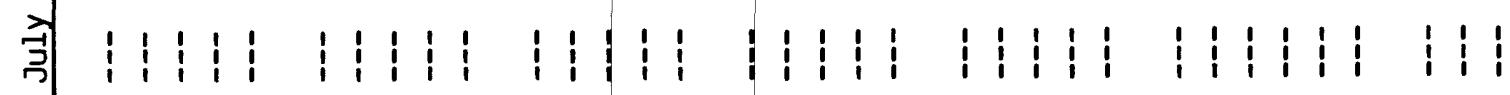

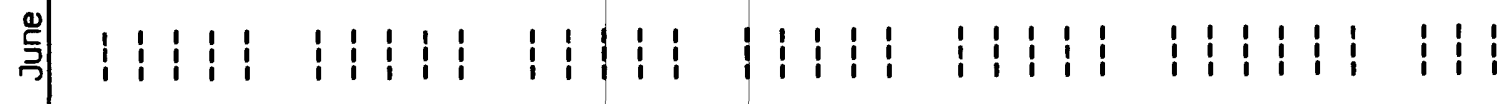

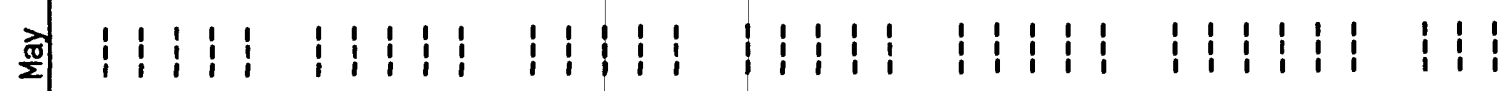

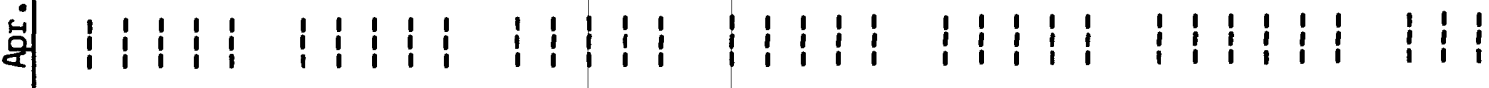

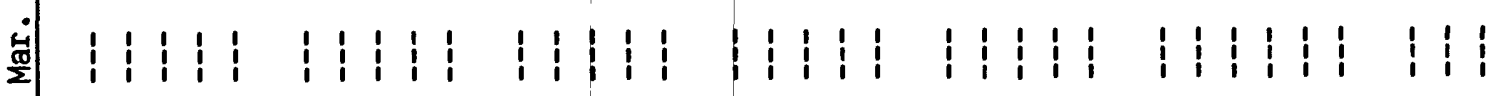

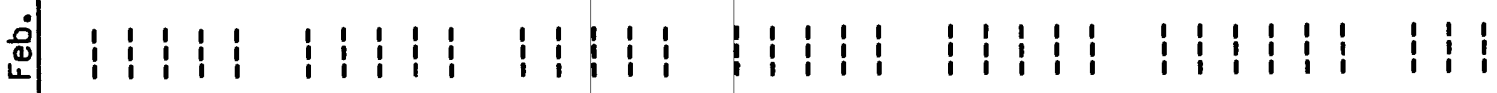

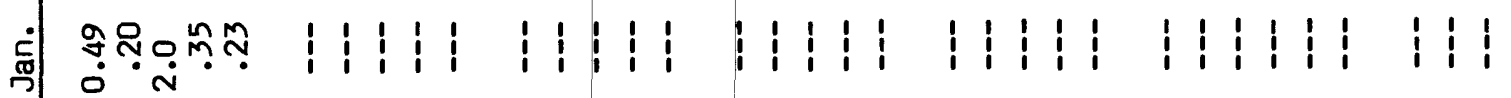

ن

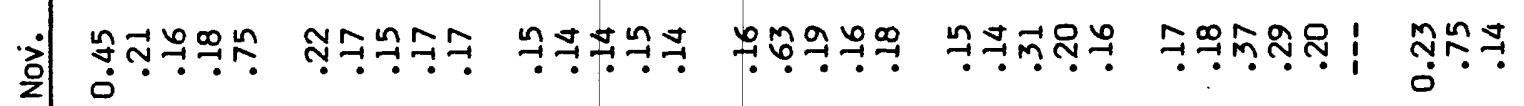

ํํㅇ

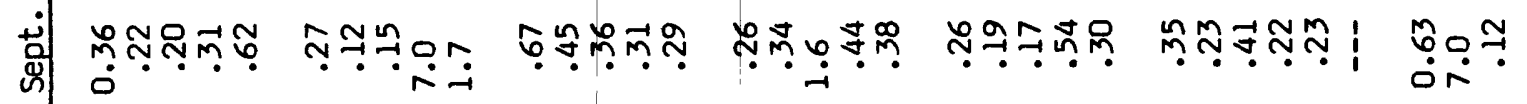

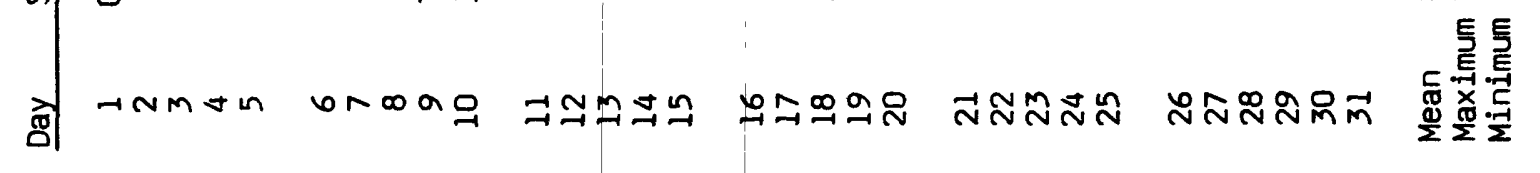




\section{Rainfall Records}

The following records of rainfall include a tabulation of daily total and monthly total rainfall at station 7 and comments on the data. $A$ detailed description of the rain-gage station, including the period of record, is given in the appendix.

The daily and monthly total rainfall at station 7 are listed in table 5. Rainfall was not recorded during August 2 and 3 because of recorder failure following a probable lightning strike. Rainfall values from the National Weather Service gage at Rimini, $2 \mathrm{mi}$ southeast of station 7 , have been substituted for those two days. The annual total rainfall during the period from January 1 to December 31 , 1988, was 34.9 inches. This is significantly less than the average annual rainfall of 46 inches for the area, reflecting the drought conditions that prevailed for much of 1988. The minimum monthly rainfall during the period of record at station 7 was 0.72 inch during June. The maximum daily and maximum monthly rainfall were 2.92 inches on September 9, and 6.22 inches during September.

\section{Discussion of Streanflow and Rainfall Patterns}

Streamflow patterns reflect the characteristics of a drainage basin and the rainfall history in the basin. Changes in the patterns of the streamflow record, or differences in flow characteristics between basins, may reflect the effects of variations in land use. Records of streamflow are also the basis for calculating loads of sediments and chemical constituents transported from a given drainage basin to Lake Marion and the adjacent wetlands. Low flows are generally dominated by ground-water contributions to streamflow, and chemical loads during low-flow periods generally reflect the chemistry of the ground water. High flows typically reflect increased surface runoff. Stream sediment loads increase significantly during high flows owing to erosion of sediment from the land surface and to resuspension of sediment from the channel bed. Chemical loads contributed to streams by ground water are diluted during periods of high flow. Actual load calculations were not done as part of this study because the number of water samples collected for chemical analys is was insufficient to develop a relation between chemistry and flow; however, analysis of water samples that were collected demonstrated some important differences between the high-flow and low-flow stream chemistries that will be discussed in a following section. The streamflow records also provide a set of background data for comparison to future conditions when land use patterns may have changed.

The relation between streamflow at each of the four stations and rainfall at station 7 is illustrated in figures 24 through 40 . Data for stations 3, 6, and 7 are shown in figures 24 through 31 and stations 4, 5, and 7 in figures 32 through 40.

All of the streams generally respond to the rain events recorded at the rain gage, indicating that typical rainstorms are sufficiently large to affect all of the gaged streams simultaneously. No attempt was made to quantify the amount of rain falling within each drainage basin, however, because an accurate estimate would require more rain gages. 


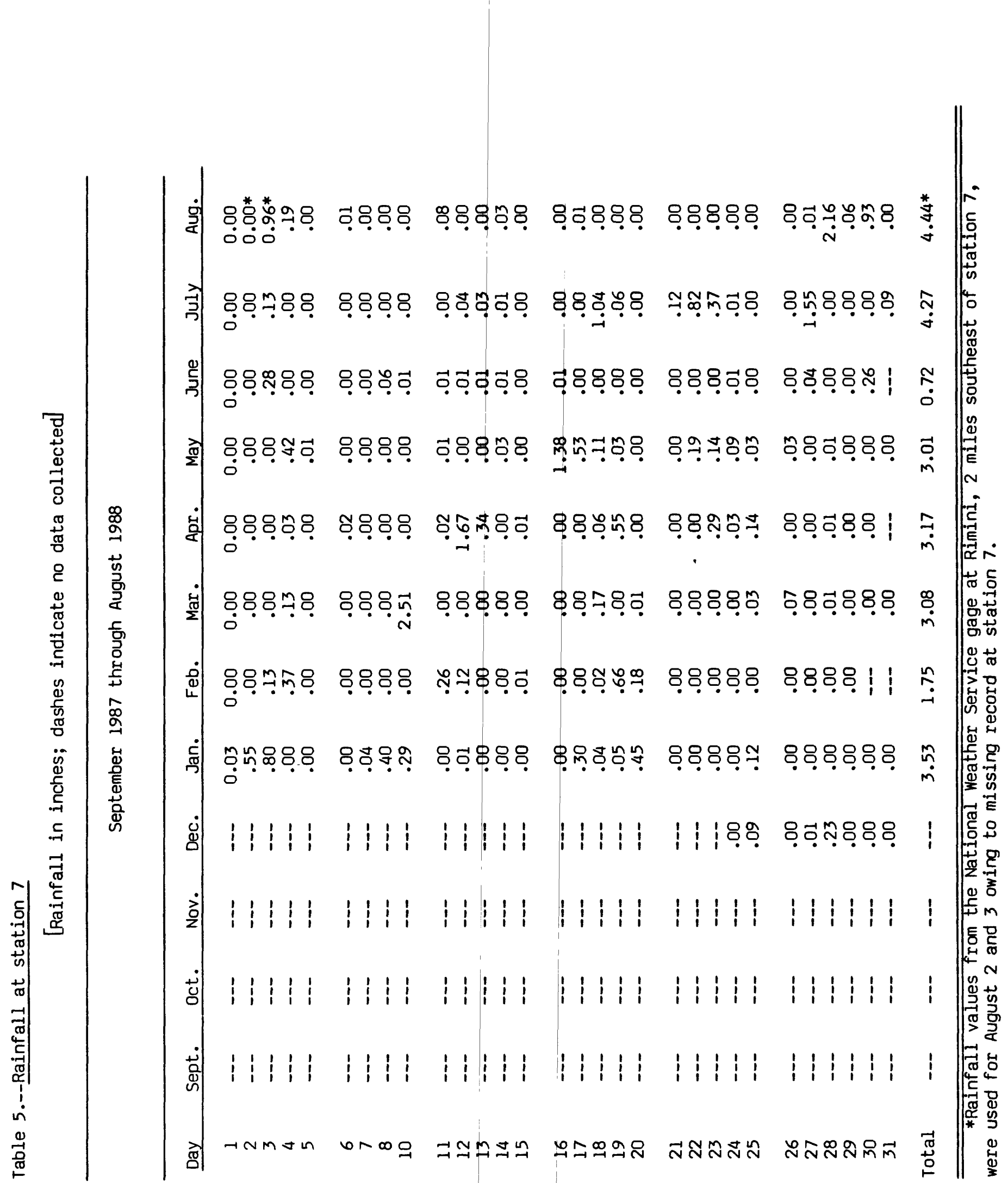




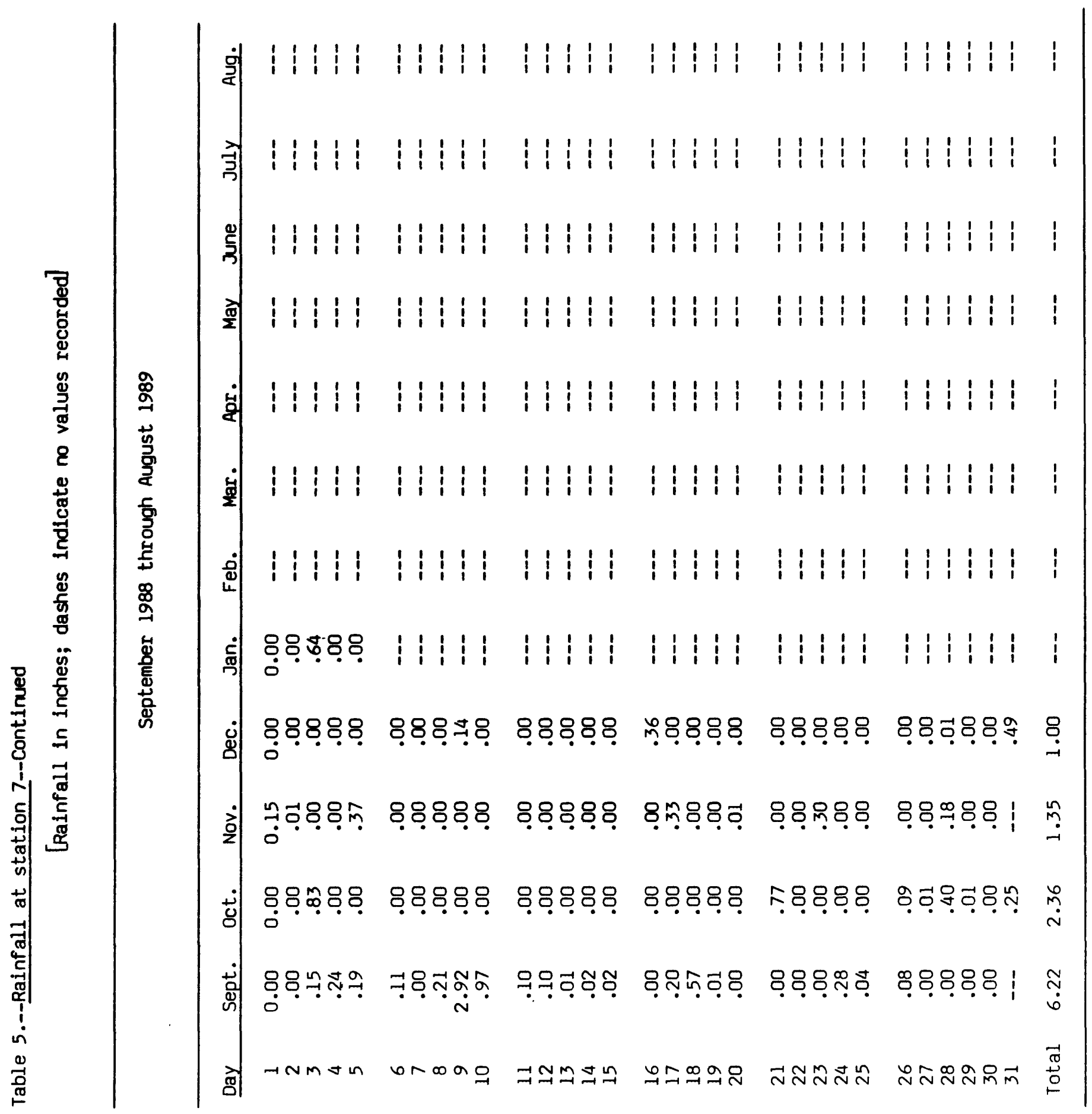




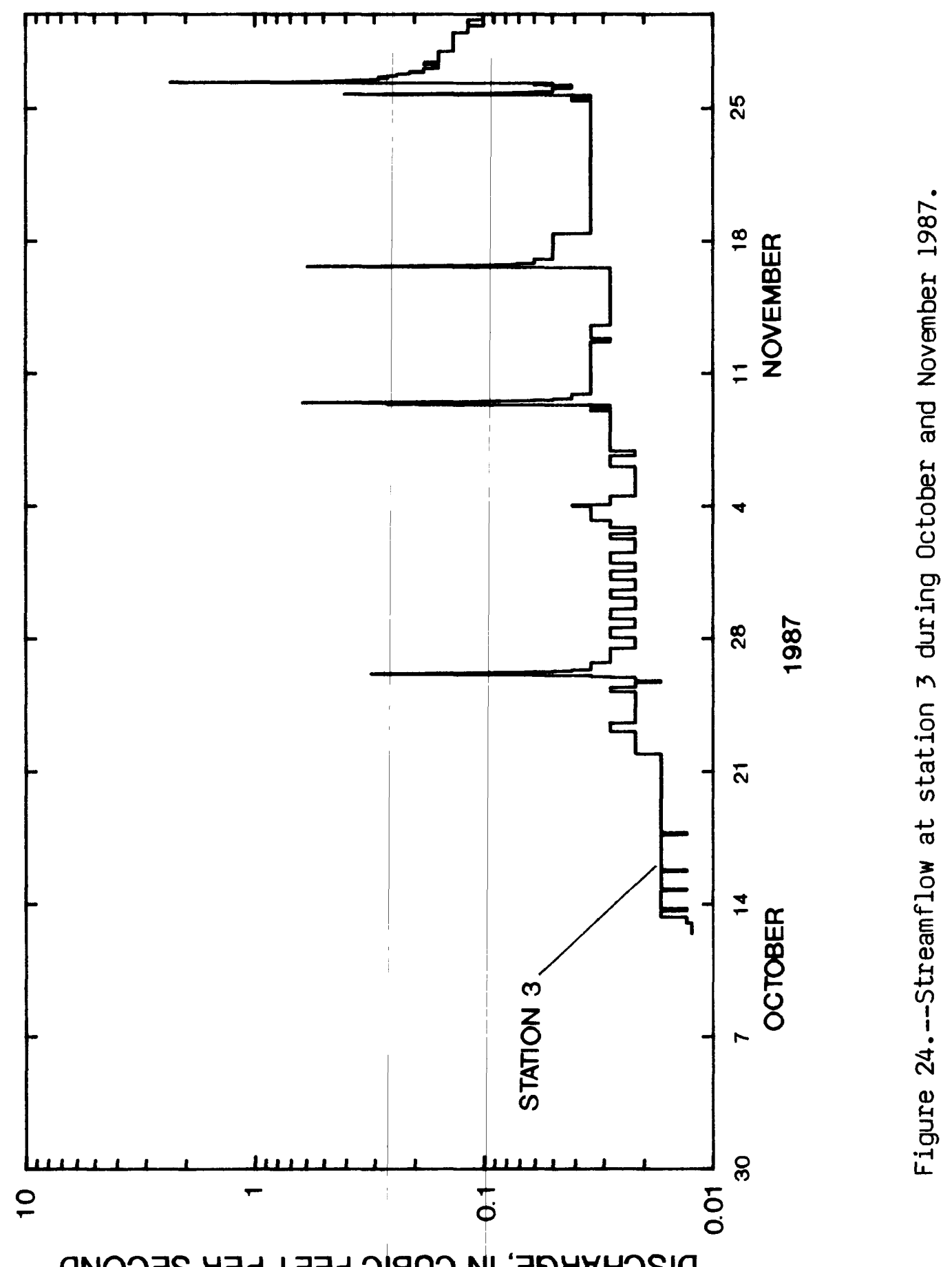




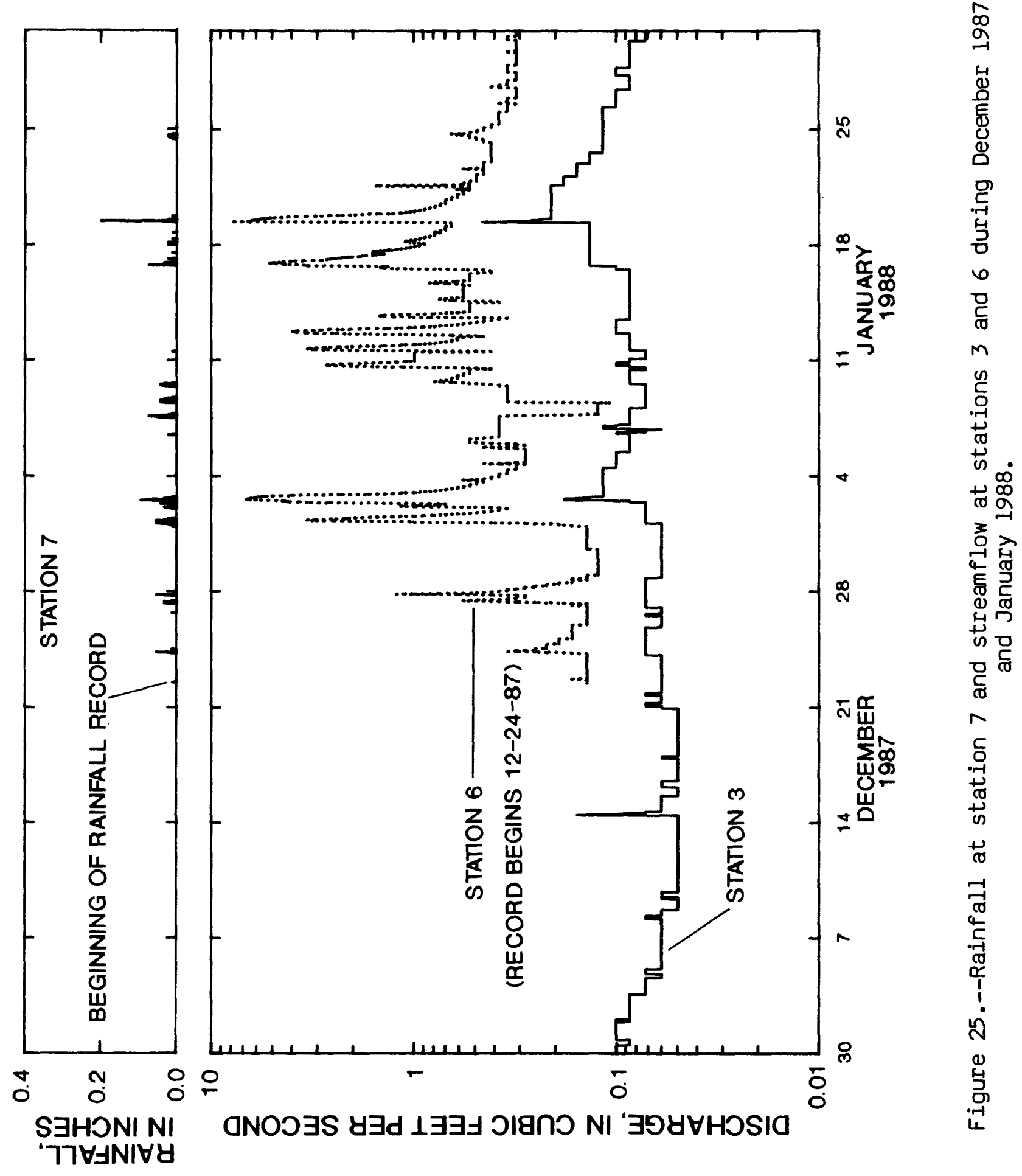




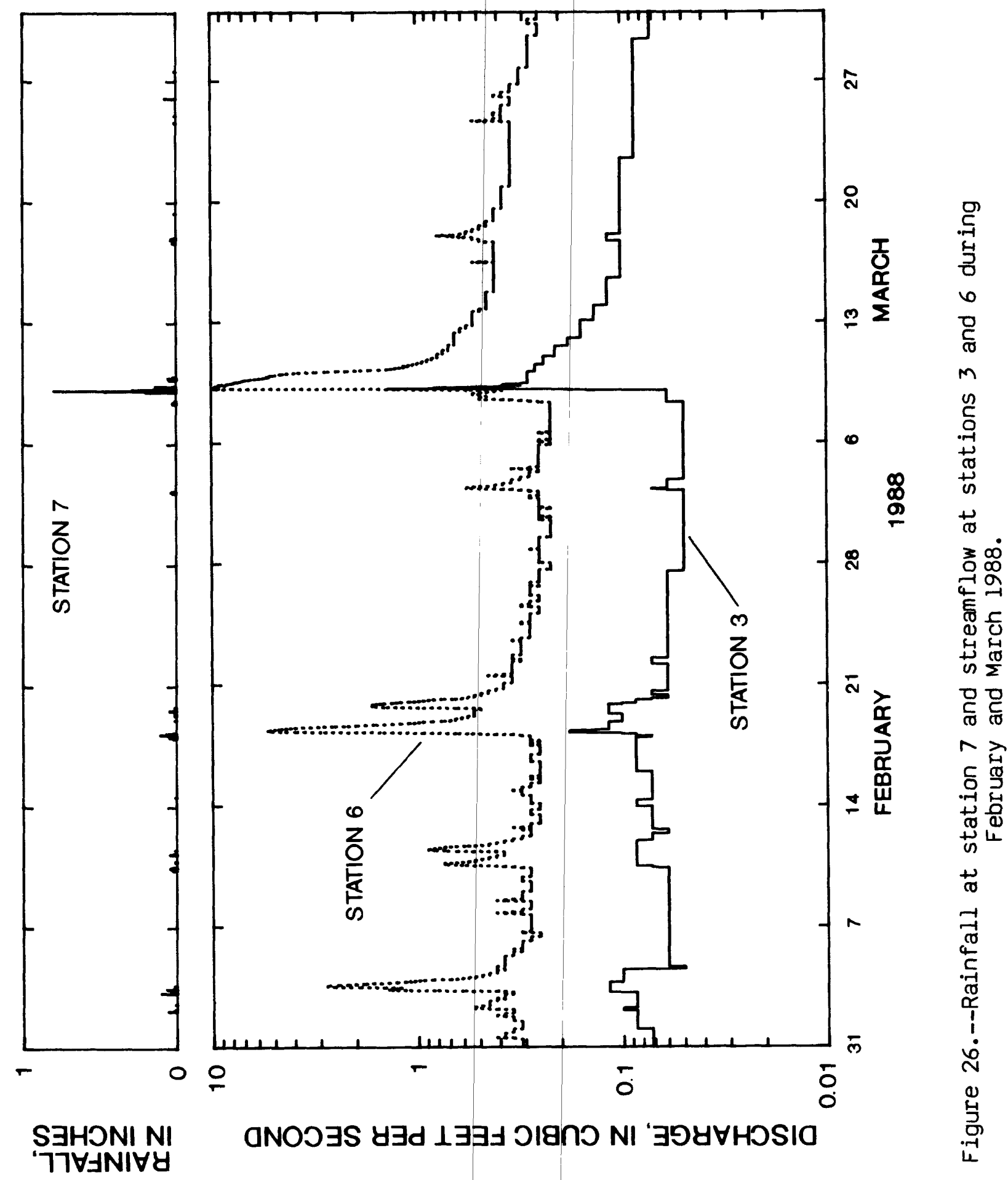




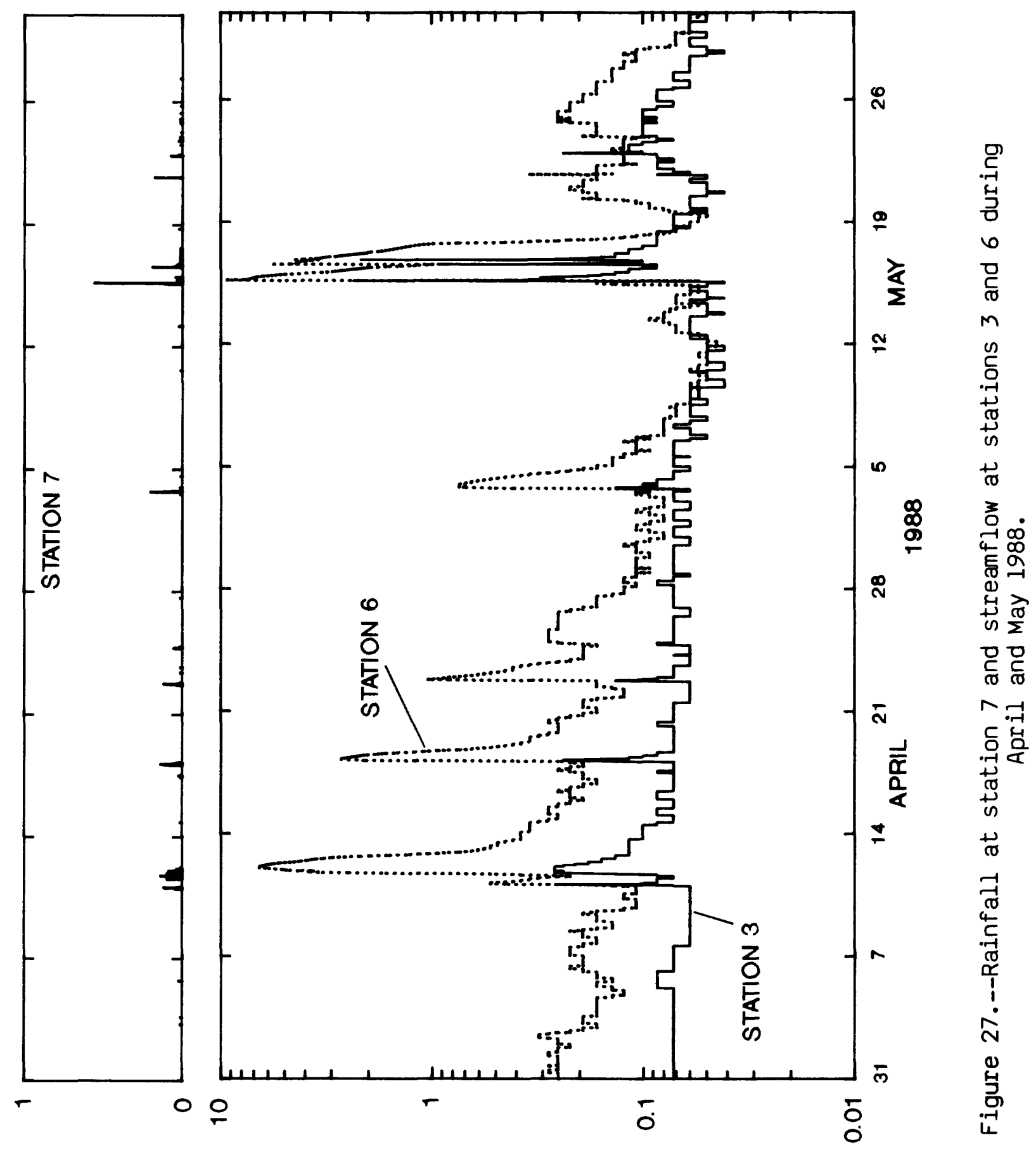

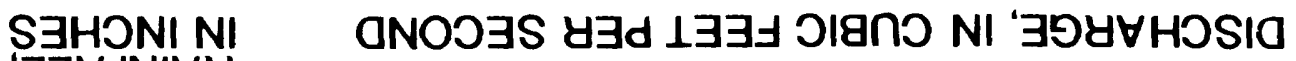
'ר $\forall$ NIVY 


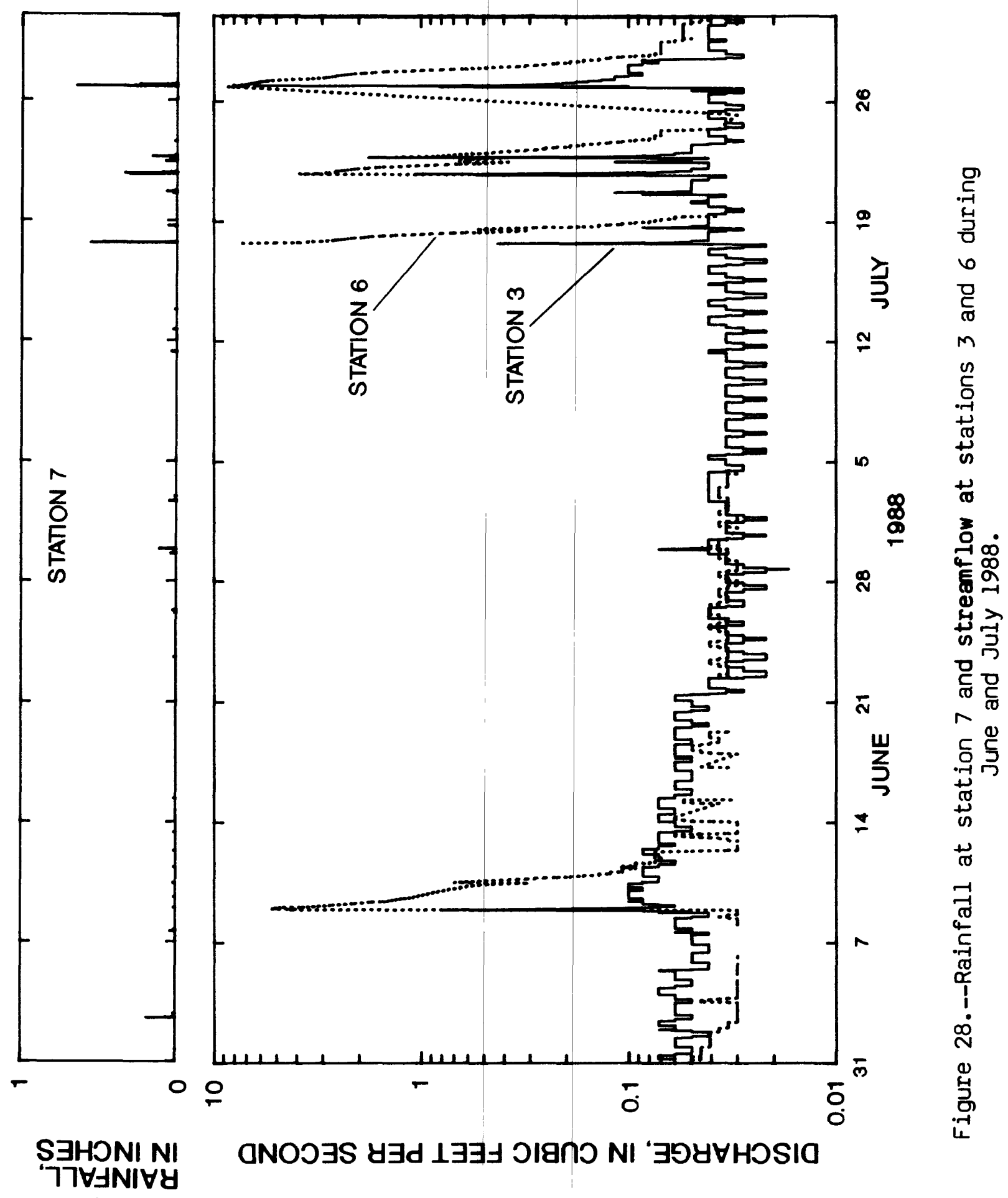



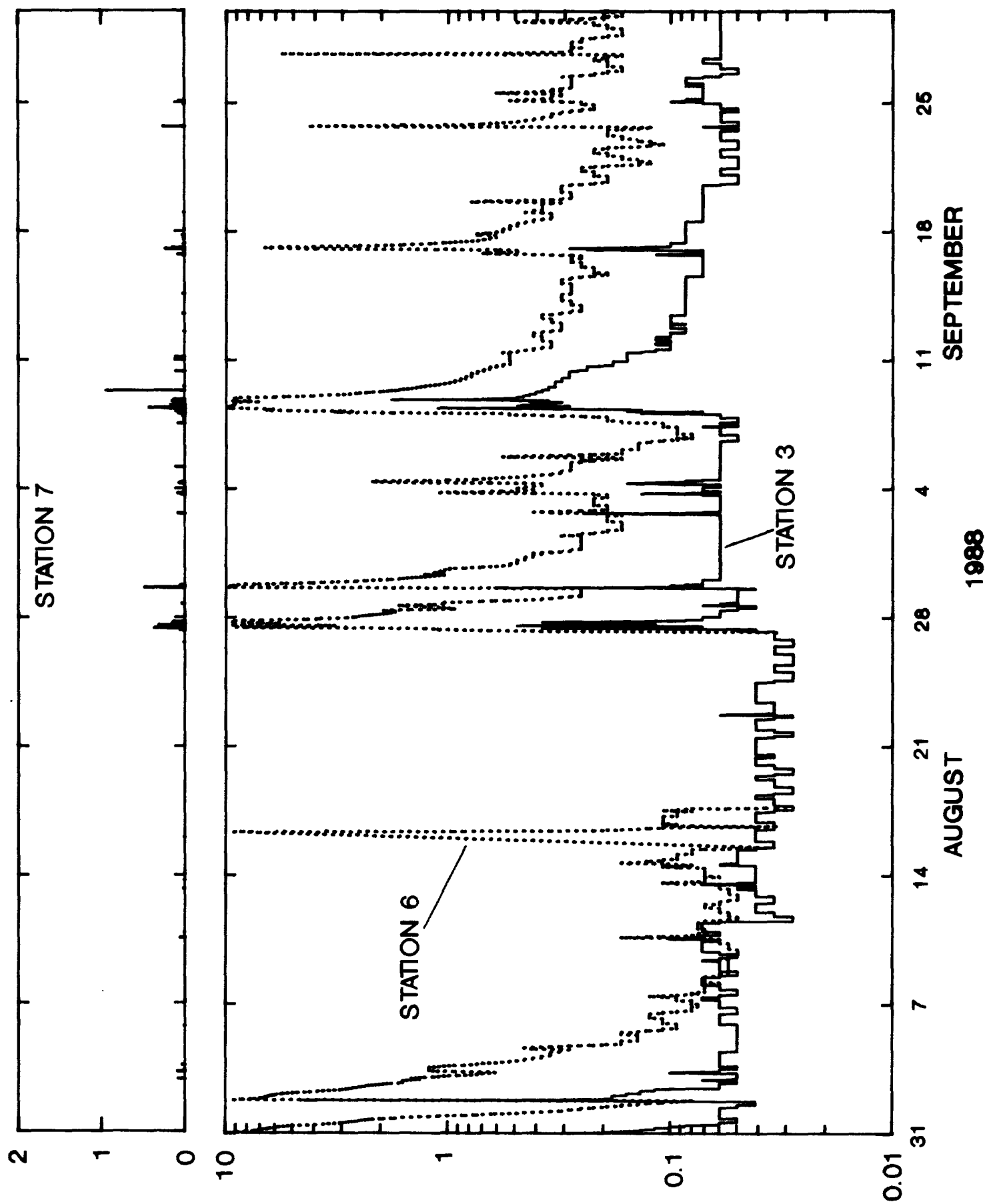

SFHONINI

aNOJ 


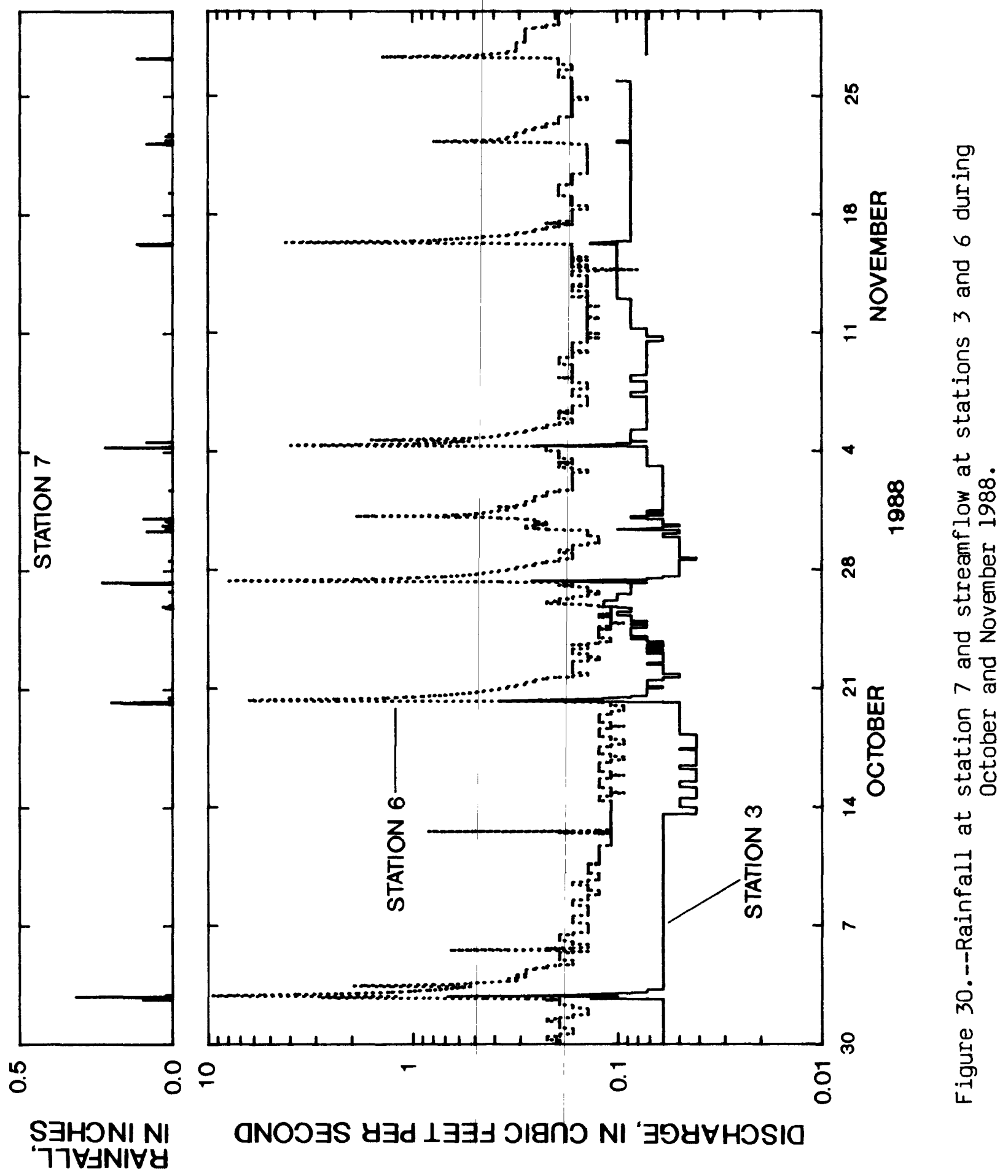




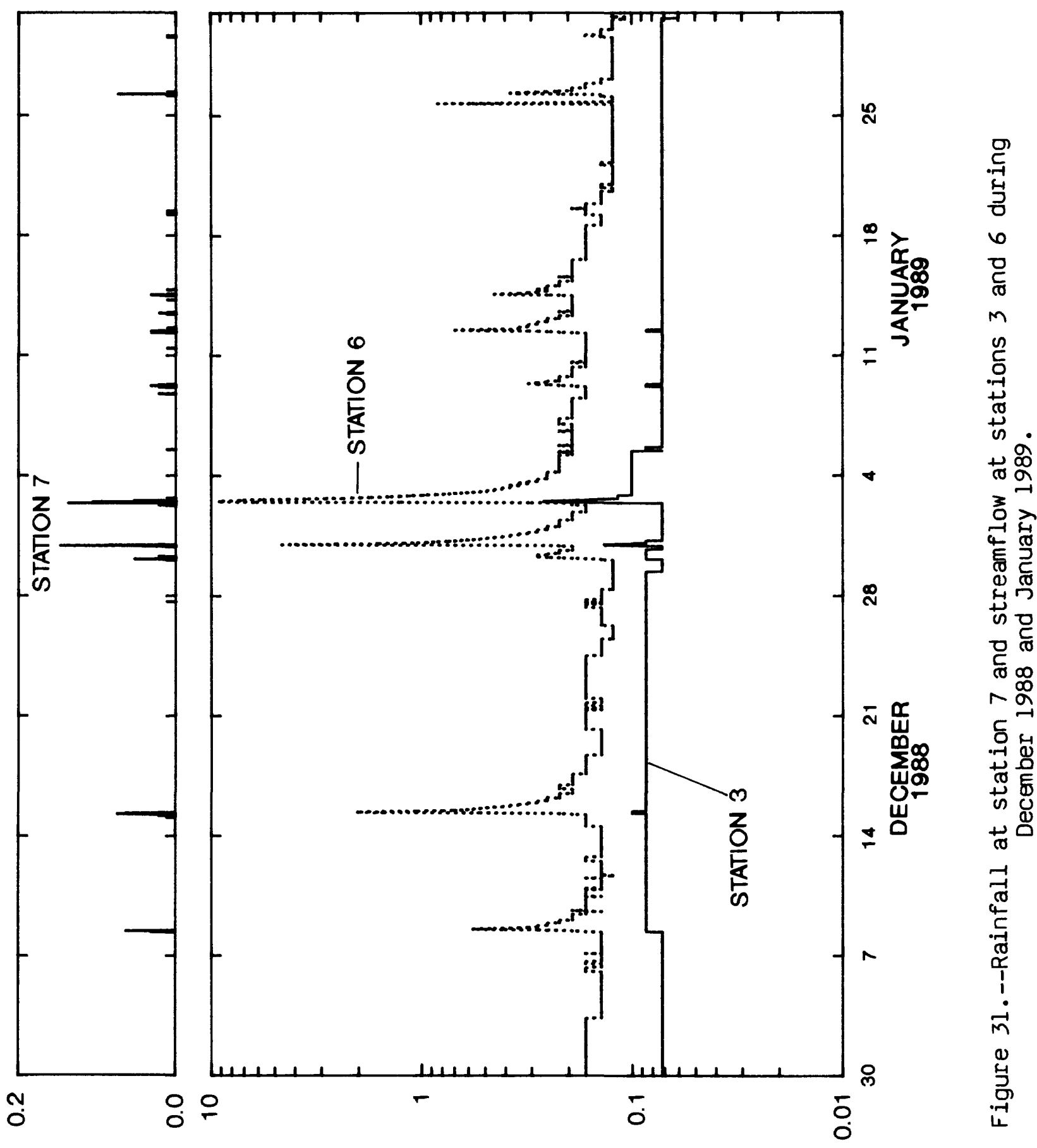

SᄏHONI NI aNOJ '7רษNIVY 


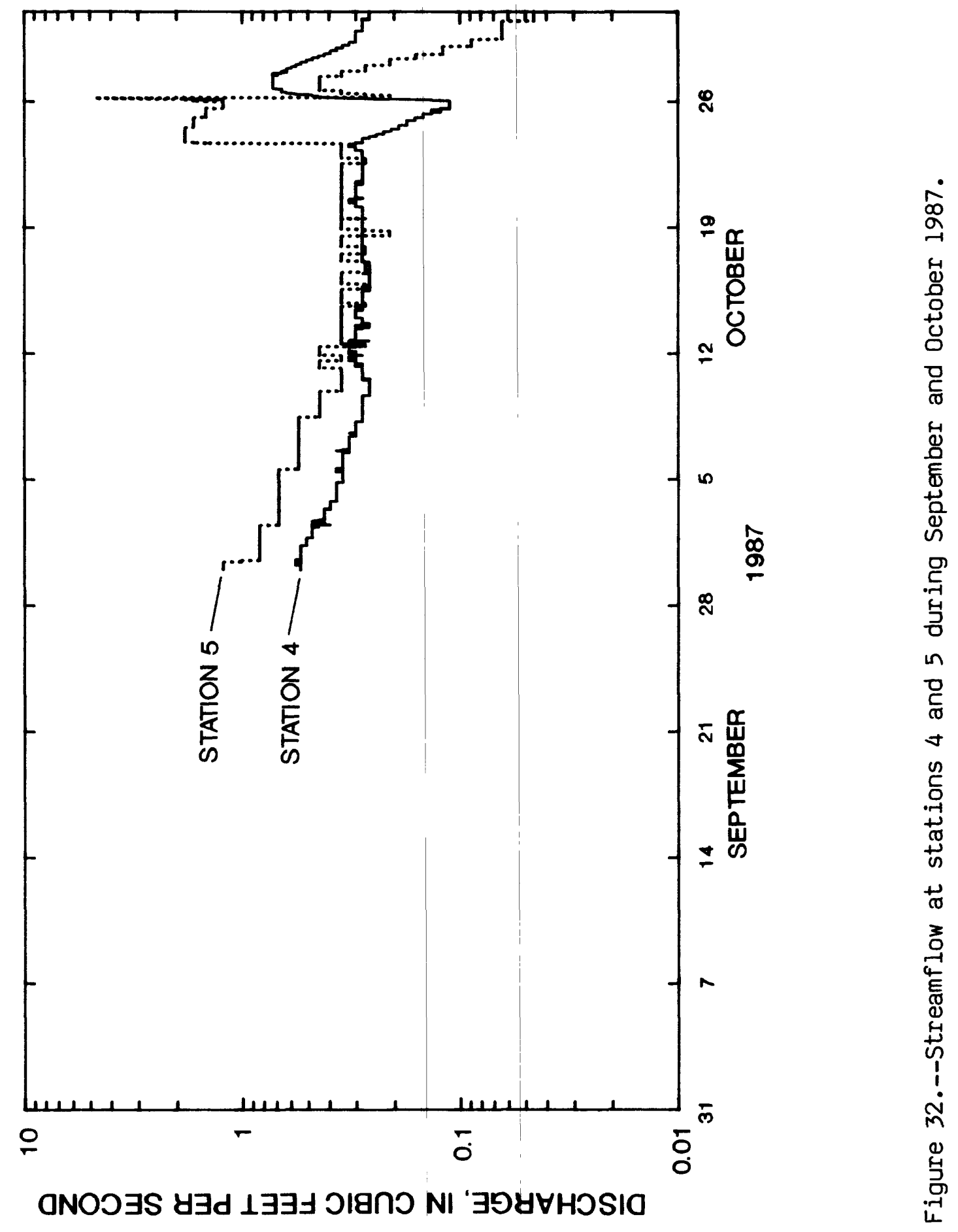




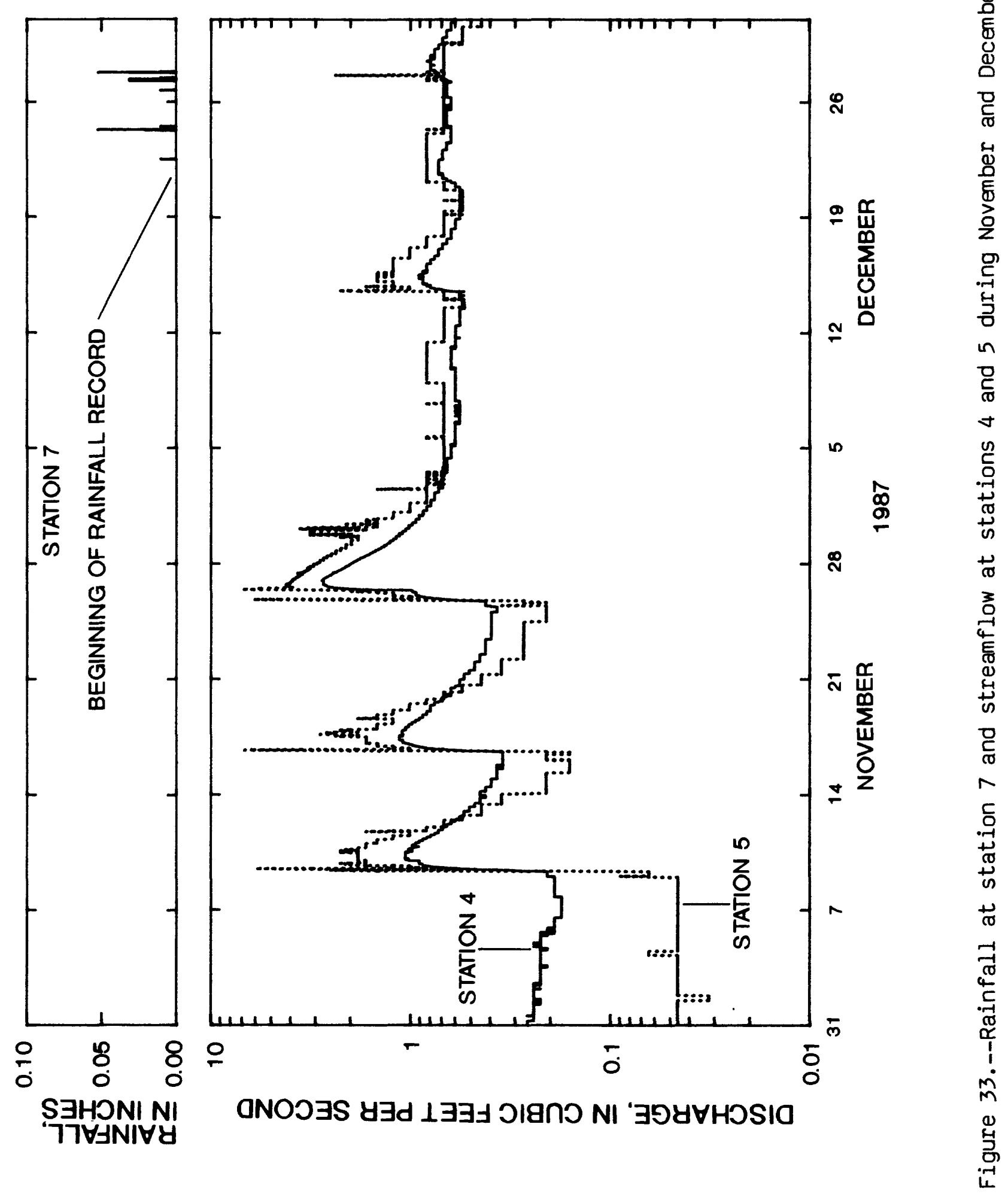




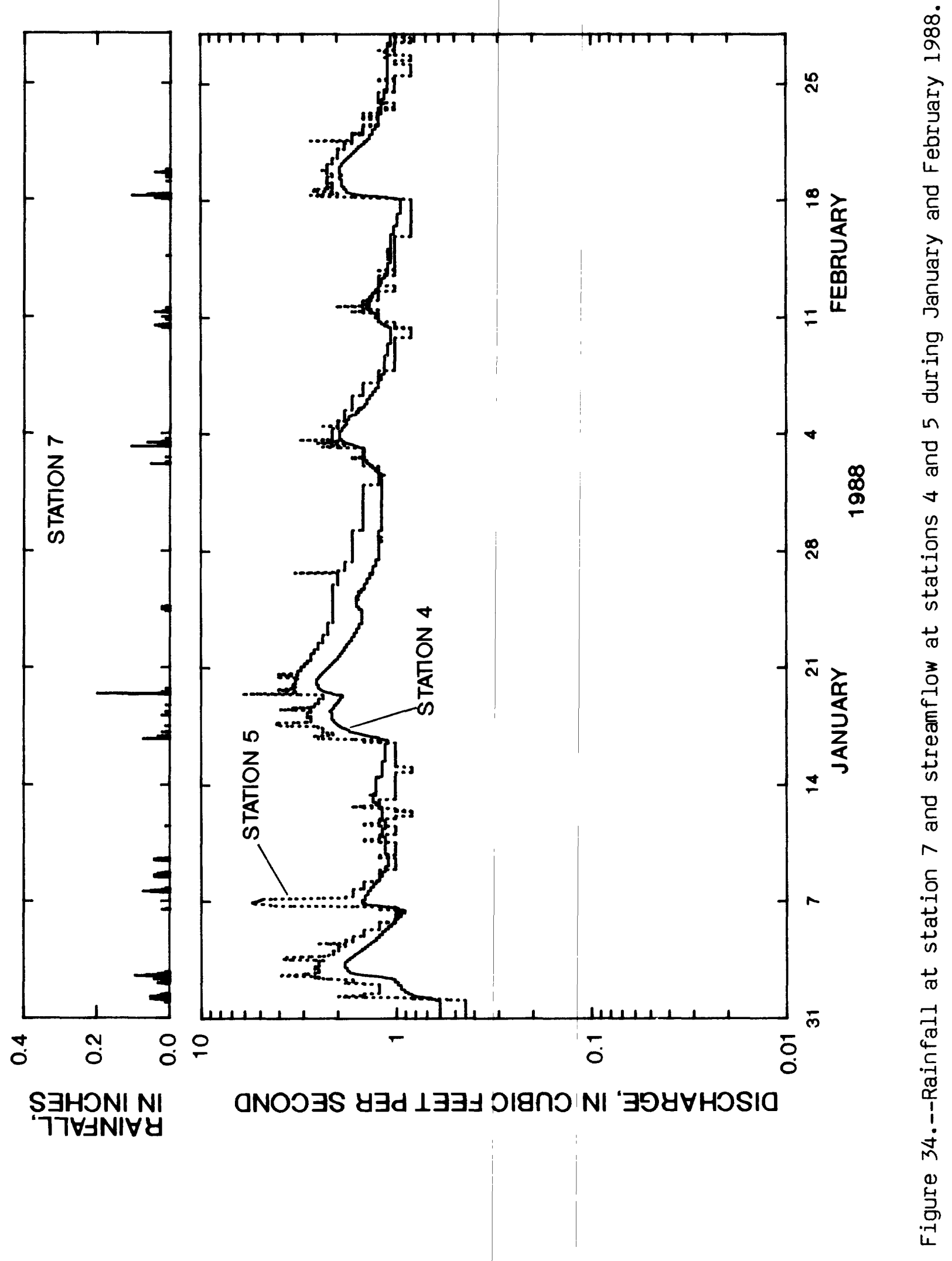



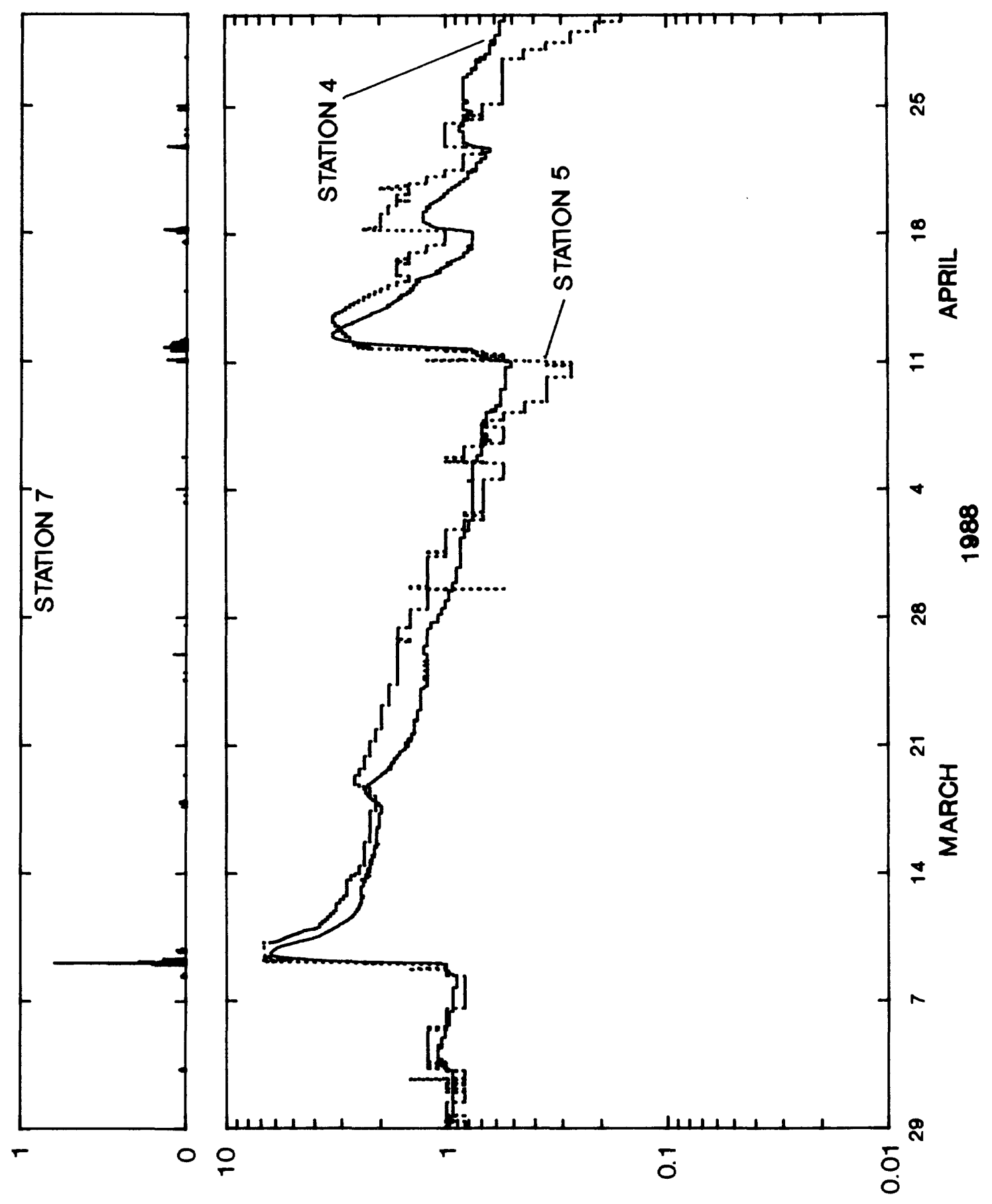

SᄏHONINI ONOJ NS y ר7甘 NIVU 

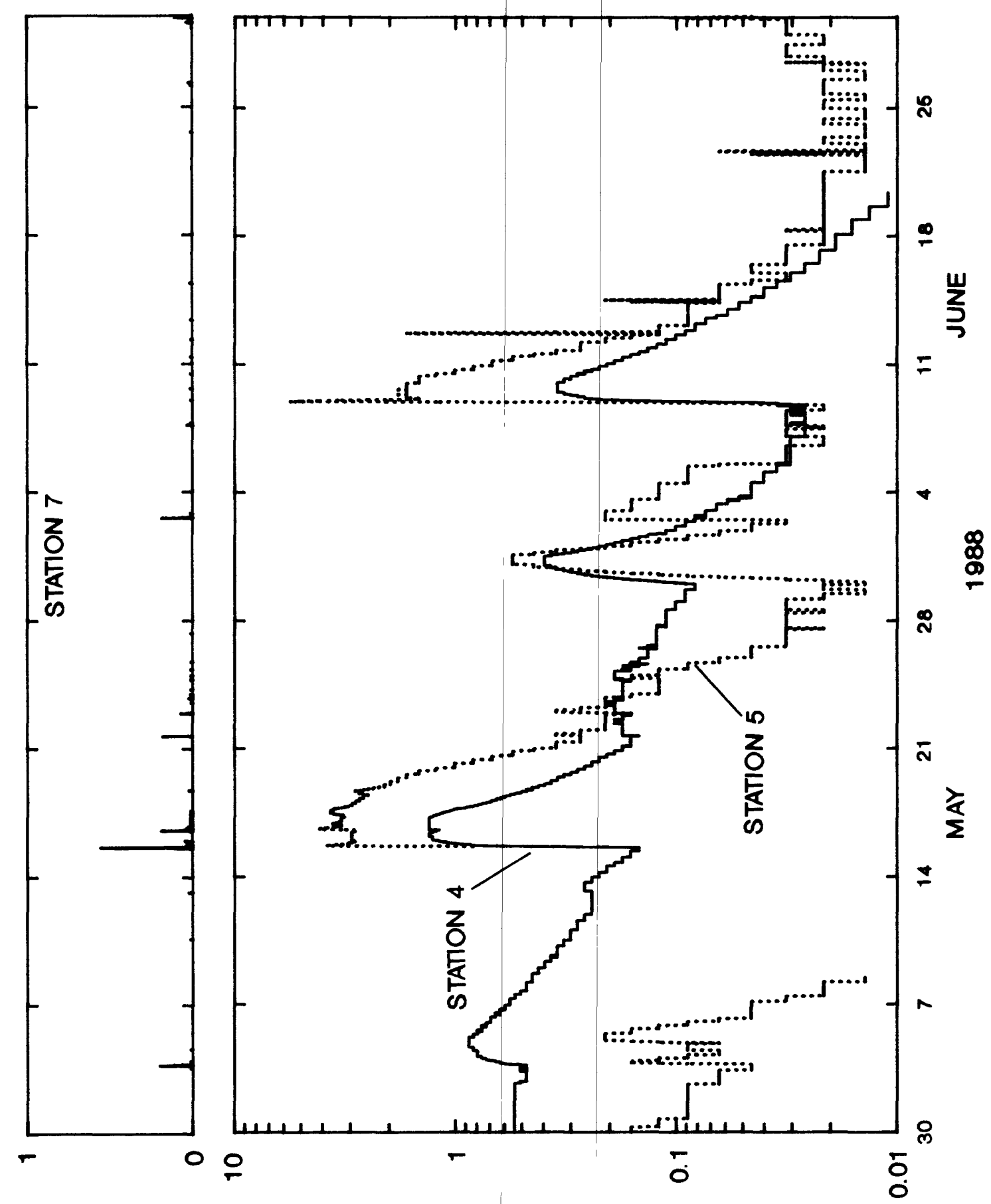

SᄏHONI NI

aNOJ $77 \forall$ NIVY 


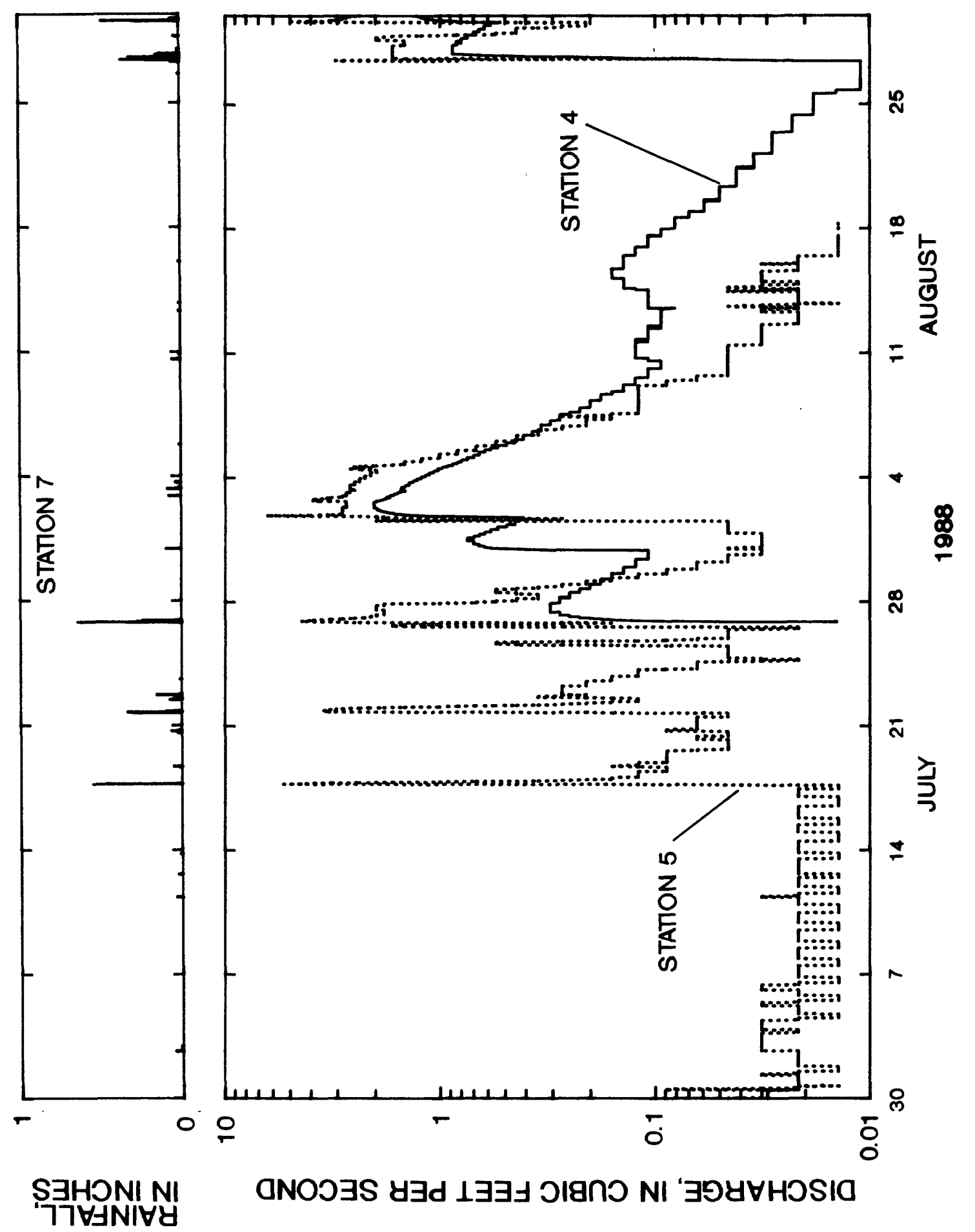



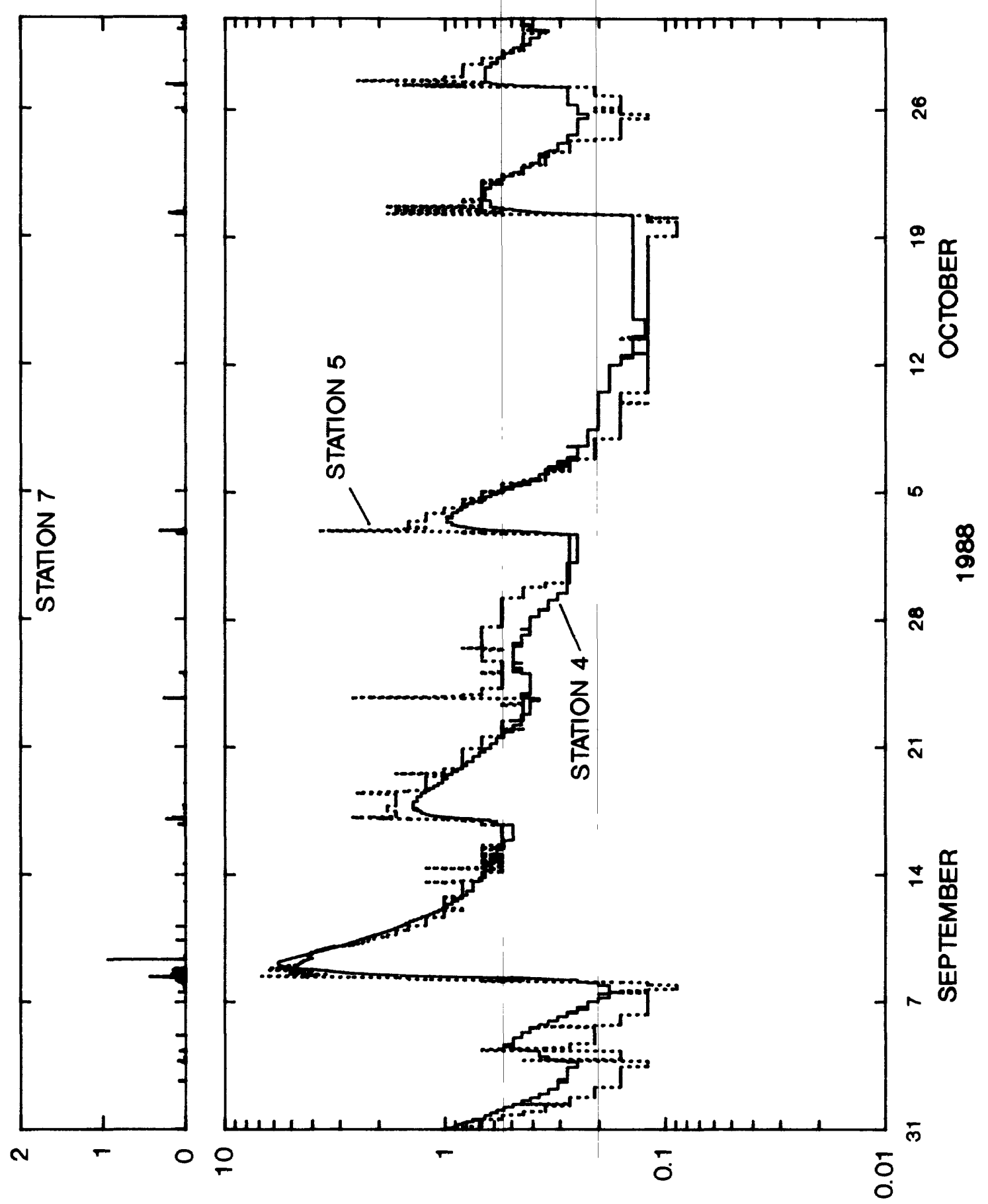

SᄏHONI NI

aNOJ $\exists S$ \&

'77 $\forall$ NIVY

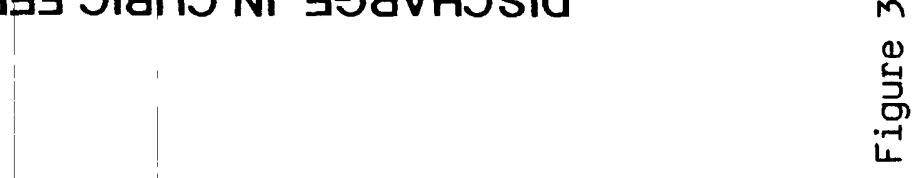




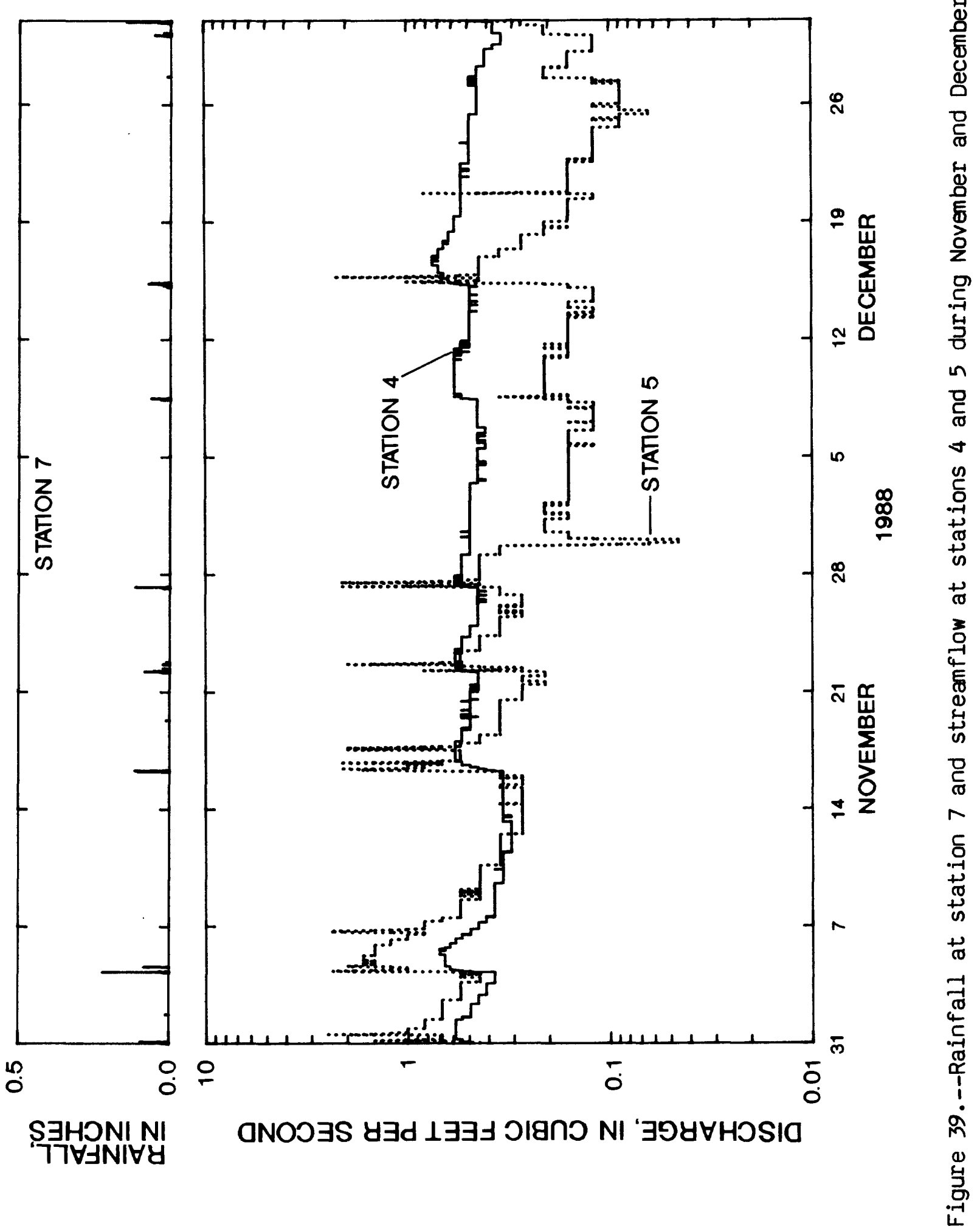




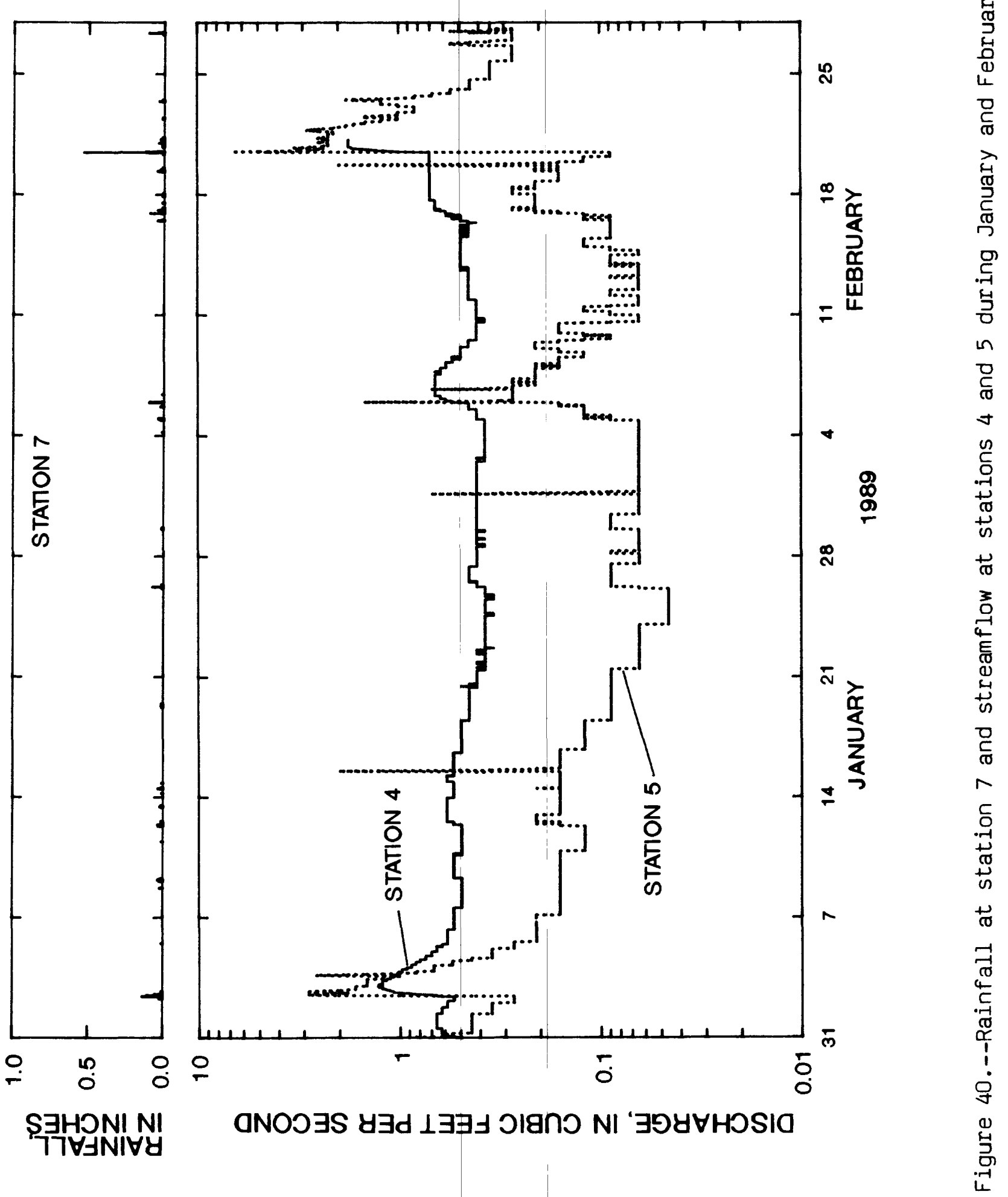


The streamflow values generally reflect the size and condition of the drainage basins. Station 3 is characterized by the lowest flow and by rapidly rising and falling hydrographs, to be expected in the small and relatively undisturbed drainage basin C (fig. 3). Station 6 exhibits the highest peak flows, along with rapidly rising and falling hydrographs. The high peak flows, relative to those observed at stations 4 and 5 , are probably due to the high percentage of cleared land in drainage basin $A$ associated with the landfill site. Higher monthly mean flow during rainy months at stations 4 and 5 (tables 2 and 3 ) than at station 6 (table 4) reflect the larger drainage areas, and the more attenuated hydrographs at stations 4 and 5 are probably due to more vegetation and the effects of several small dams in the basins.

Stations 4 and 5, located at different points on the same stream, tend to track each other closely, although the flows at station 5 generally are higher at the crests of the hydrographs, reflecting the larger drainage area associated with station 5. Monthly mean flows (tables 2 and 3 ) generally are higher at station 5 than at station 4 for the same reason.

\section{QUALITY OF WATER AND SEDIMENT}

Stations 1 through 6 (fig. 2) were used as sample collection sites for determining chemical and biological quality characteristics of water and sediment from the streams and Lake Marion in the vicinity of the hazardouswaste landfill. Stations 1, 3, and 4 are considered to represent background conditions with regard to the influence of the landfill because they lie outside the area of overland flow or lake flow from points of discharge in the landfill facility. Stations 2, 5, and 6 are located in areas that receive drainage from the landfill facility and thus could possibly be affected by landfill activities. The purpose of this water- and sediment-quality investigation is to establish a background data base with which future measurements can be compared and to compare areas within the influence of the landfill with the background areas to determine if any significant differences exist.

Water samples were collected from each of the six stations in November 1987 and January, April, and July of 1988. The water samples collected in November and January were analyzed for chemical and physical characteristics, including concentrations of major ions, nutrients, trace elements, and other priority pollutants as designated by the Environmental Protection Agency, 1986 (USEPA). These priority pollutants included acidand base/neutral-extractable organic compounds, volatile organic compounds, organochlorine compounds, gross polychlorinated biphenyls, and gross polychlorinated naphthalenes. Water samples collected in April and July were analyzed for physical characteristics and concentrations of major ions and trace elements. Lakebed and streambed sediments were collected at each station during the November and January sampling periods and analyzed for concentrations of trace elements, acid-base/neutral-extractable organic compounds, organochlorine compounds, gross polychlorinated biphenyls, and gross polychlorinated naphthalenes. 


\section{Sample Collection and Analysis}

Alkalinity, specific conductance, $\mathrm{pH}$, and temperature of the water were measured in the field according to the methods described by Wood (1976). Dissolved oxygen was measured in the field titrametrically (American Public Health Association, 1981, p. 390) and with a dissolved oxygen meter (Wood, 1976).

Water samples were collected within $1 \mathrm{ft}$ of the water surface by hand-submersion of the sample bottle. For samples analyzed for volatile organic compounds, care was taken to exclude air bubbles by completely filling the bottle and capping it under water. Selected samples analyzed for volatile organic compounds were field spiked with a surrogate standard solution to examine the potential for losing volatiles during sampling, shipping, and analysis. Surrogate recovery for three compounds averaged 106 percent, indicating losses were negligible. All water samples (except those for nutrient analysis) were shipped on ice and analyzed by the U.S.

Geological Survey laboratory. Major ions and trace elements were analyzed according to the methods described by Fishman and Friedman (1985). Organic compounds were analyzed according to the methods described by Wershaw and others (1987). Nutrient samples (total organic plus ammonia nitrogen, ammonia plus ammonium, nitrate plus nitrite, phosphorus, and or thophosphate) were collected and analyzed by the South Carolina Public Service Authority laboratory.

Streambed and lakebed sediments analyzed for organic compounds were collected with a 2-inch diameter stainless steel corer. Samples collected during November 1987 were taken from the upper 2 inches of the streambed or lakebed. Samples collected during January 1988 were taken from the upper 6 inches of the streambed or lakebed to include sediments that are probably older than those collected in November 1987. Approximately six samples were collected along a cross section of the channel at each stream site, composited, and shipped on ice to the U.S. Geological Survey laboratory. Lakebed sediments were collected at a single point. Samples of the bulk sediment were analyzed according to the methbds desribed by Wershaw and others (1987).

Sediment analyzed for trace elements was collected with either a plastic or glass scoop, otherwise the collection procedure for metals was the same as that used for organics.

\section{Results of Analyses}

The results of chemical analysis of water and sediment show some significant differences among sampling sites, some of which are related to the landfill and others that are not. The more significant properties and constituents, which characterize the differences and similarities, are discussed in this section. A summary of the ranges of these properties and constituents is given in table 6 , which also groups the collection stations according to their location (background sites or sites downstream of the landfill). 


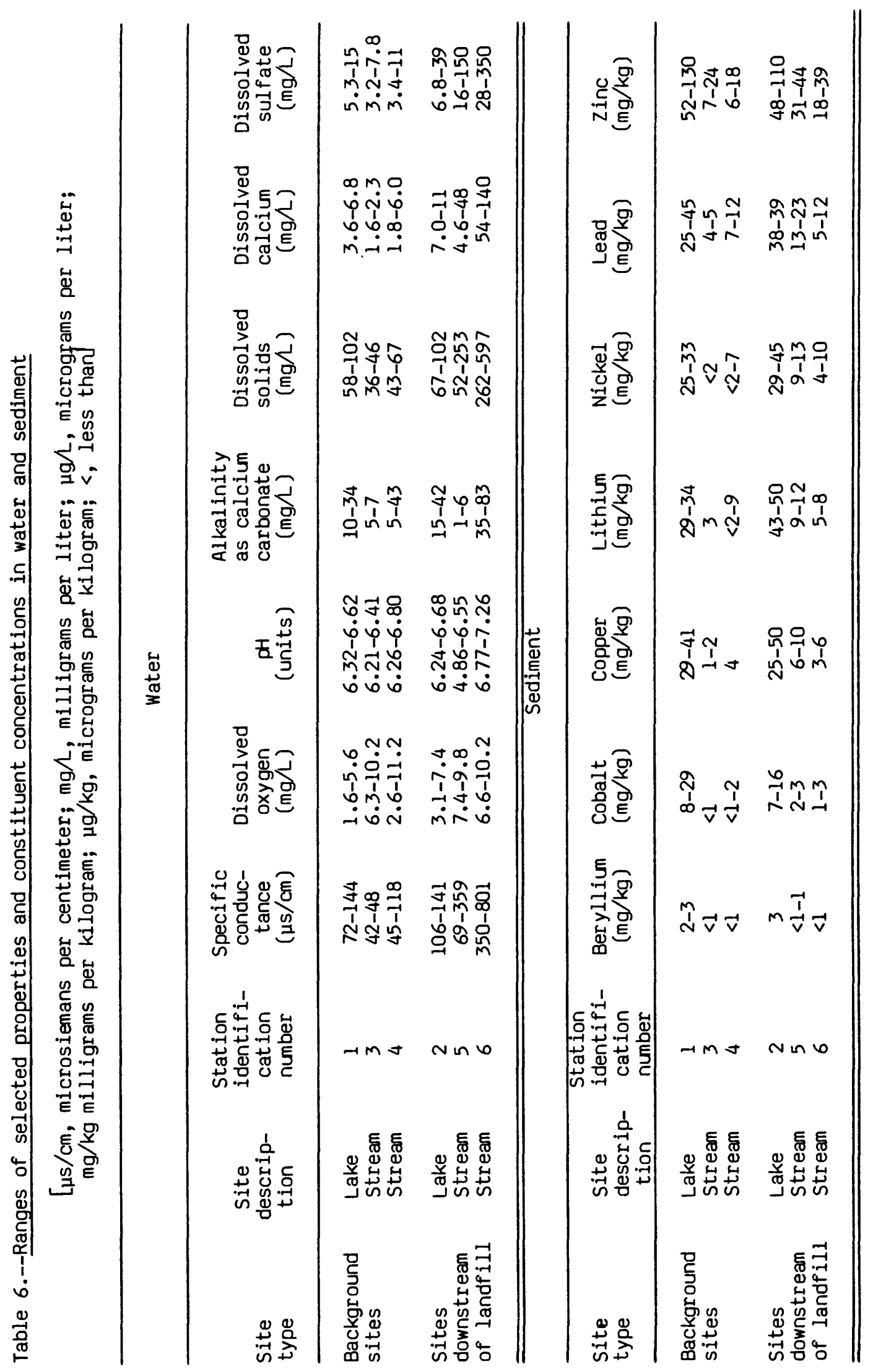




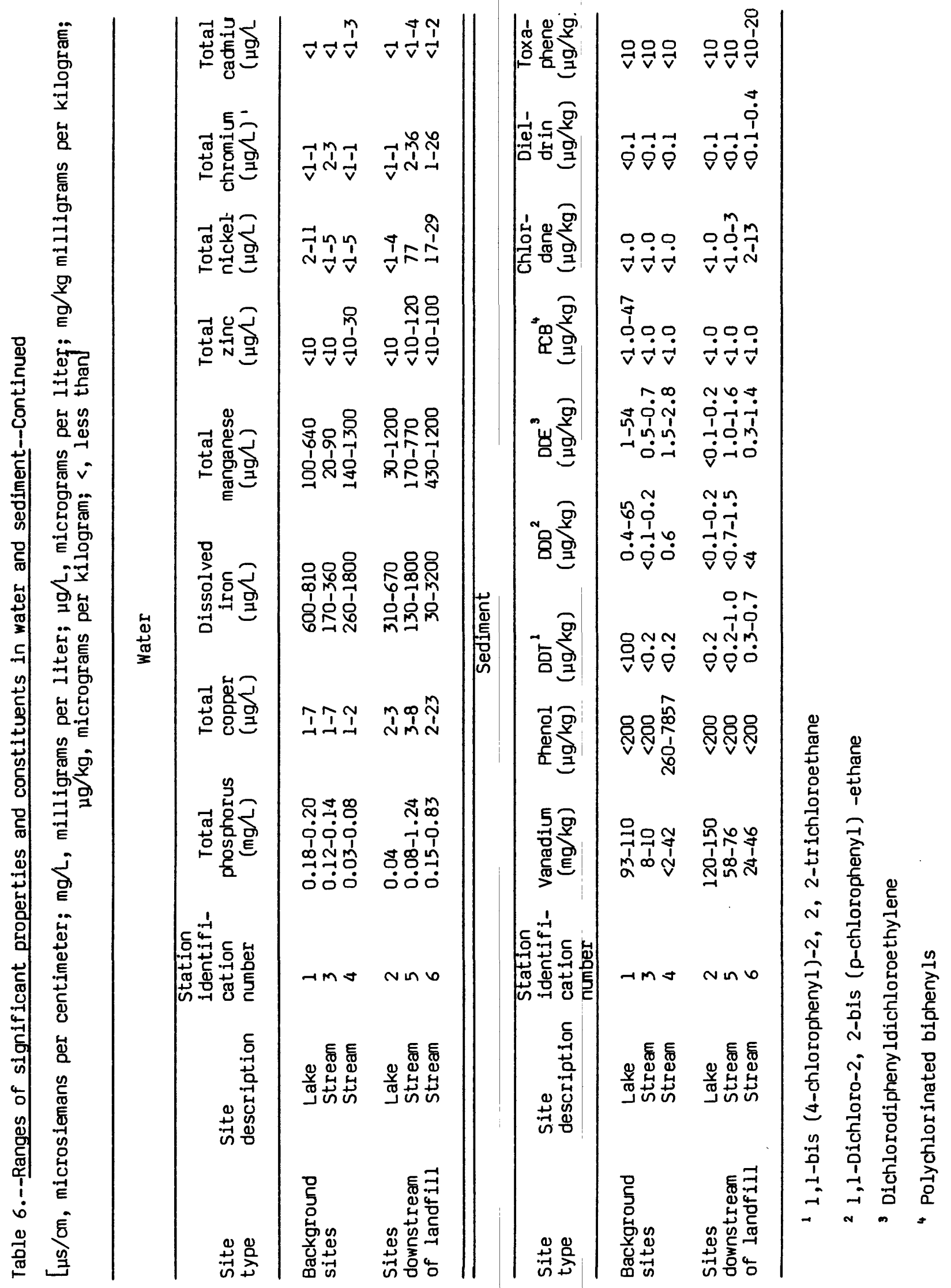


Chemical analyses of water and sediment are presented in tables 7 through 13. The designation "dissolved" in the tables refers to the concentration of the constituent that is actually in solution plus whatever particulates passed through a 0.45 -micron filter. The designation "total" refers to the concentration both in solution and in the particulates of an unfiltered sample. Streamflow measurements made while sampling sites 3 through 6 are included in table 7 . Conclusions drawn regarding significant differences in mean concentrations among sites are based on Cochran's Approximation of the Behrans-Fisher Students t-test calculated at a significance level of 0.05 (South Carolina Department of Health and Environmental Control, 1987), assuming a normal sample distribution.

\section{Inorganic Constituents and Properties in Water}

With regard to inorganic chemistry, the water samples from stations 1 through 6 exhibit significant variability. Specific conductance ranges from 42 to $801 \mu \mathrm{s} / \mathrm{cm}$. Dissolved oxygen ranges from 1.6 to $11.2 \mathrm{mg} / \mathrm{L}$, with stream water generally having higher concentrations than lake water. Water at stations 1 through 5 was acidic to slightly acidic with measured values of $\mathrm{pH}$ ranging between 4.86 and 6.80 . Water at station 6 was for the most part, slightly alkaline with a maximum measured $\mathrm{pH}$ of 7.26. The pH at these sites did not change significantly (maximum measured variation at any one site of 0.54 units) during the year or with varying flow conditions, except at station 5 which had a maximum measured variation of 1.69 units. The poor buffering capacity of water at station 5, reflected in the low alkalinities, is at least partly responsible for this variability in $\mathrm{pH}$.

The relative abundance of major ions in the water is illustrated on a trilinear plot in figure 4l. At stations 1 through 4 sodium-plus-potassium dominates the cations, and generally, no one anion contributed more than 50 percent of the total anions, regardless of the time of year or flow condition. In contrast, the water at stations 5 and 6 was predominantly of a calcium-sulfate type.

Differences are apparent in the concentrations of the major inorganic constituents between the background stream stations ( 3 and 4 ), and the stream stations within the influence of the landfill site ( 5 and 6 ). These differences are demonstrated in a general manner by the concentrations of dissolved solids that ranged from 36 to $67 \mathrm{mg} / \mathrm{L}$ at stations 3 and 4 and from 52 to $597 \mathrm{mg} / \mathrm{L}$ at stations 5 and 6 . The most significant differences in individual constituents and properties were for calcium, sulfate, alkalinity, and $\mathrm{pH}$. 


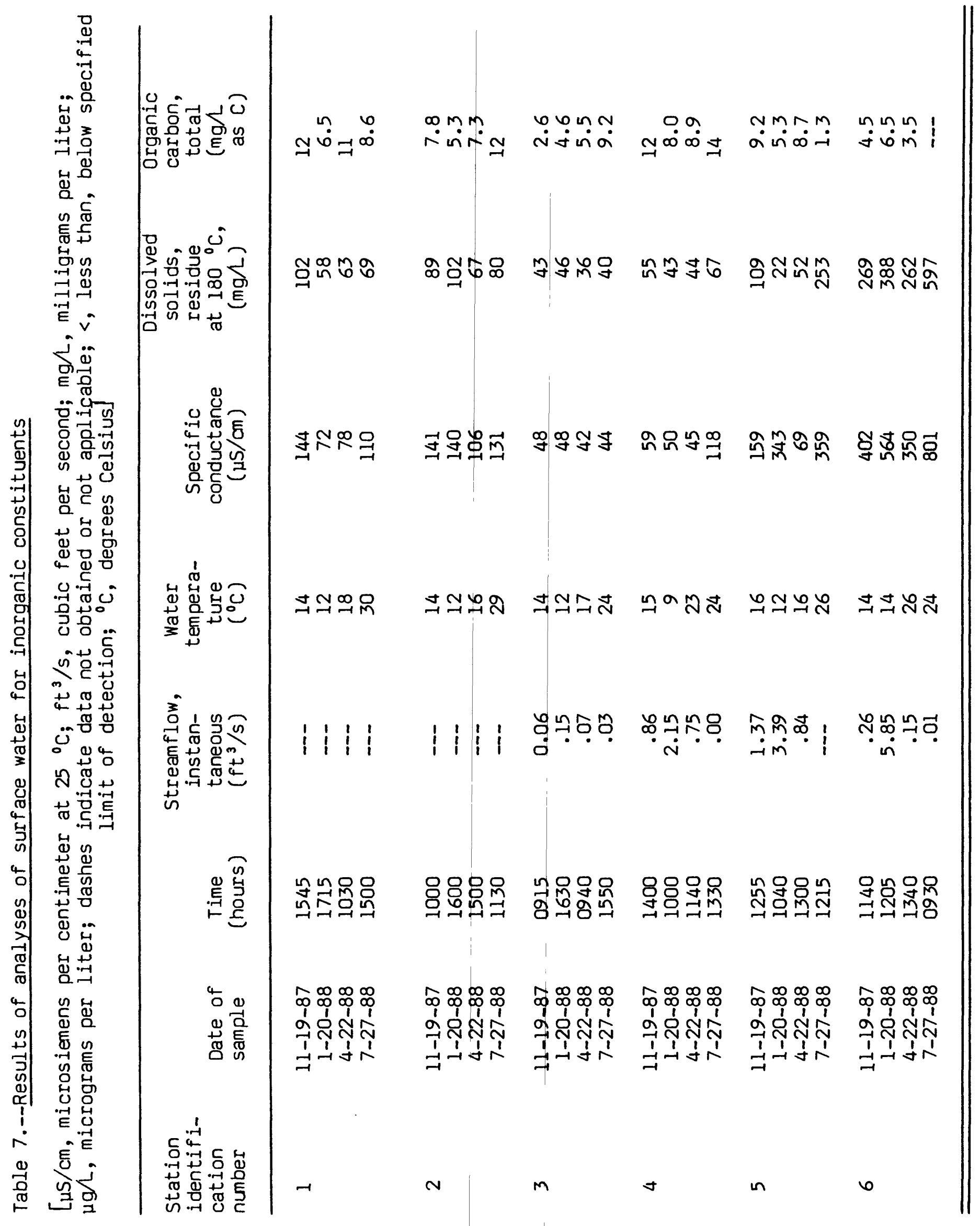




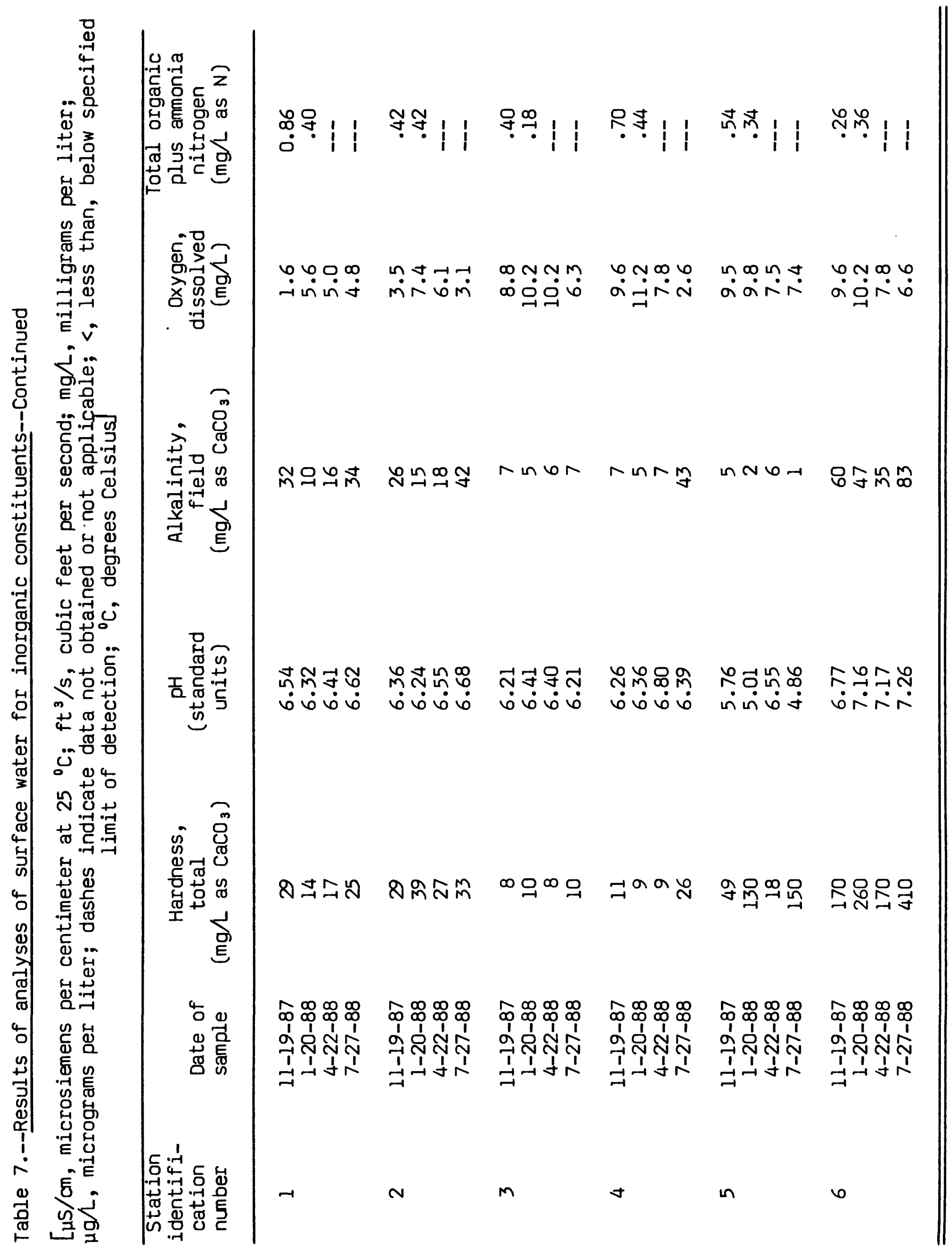




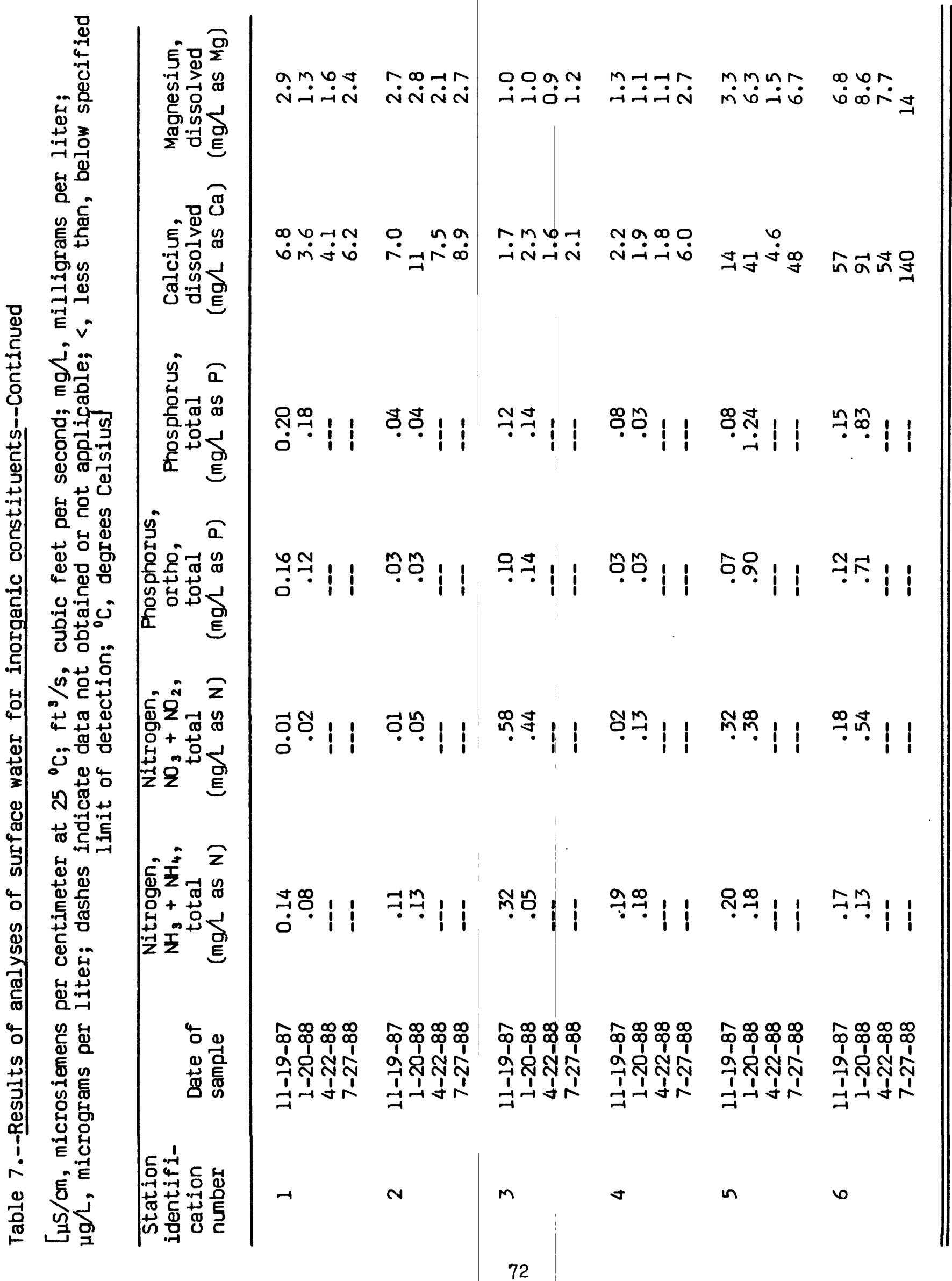




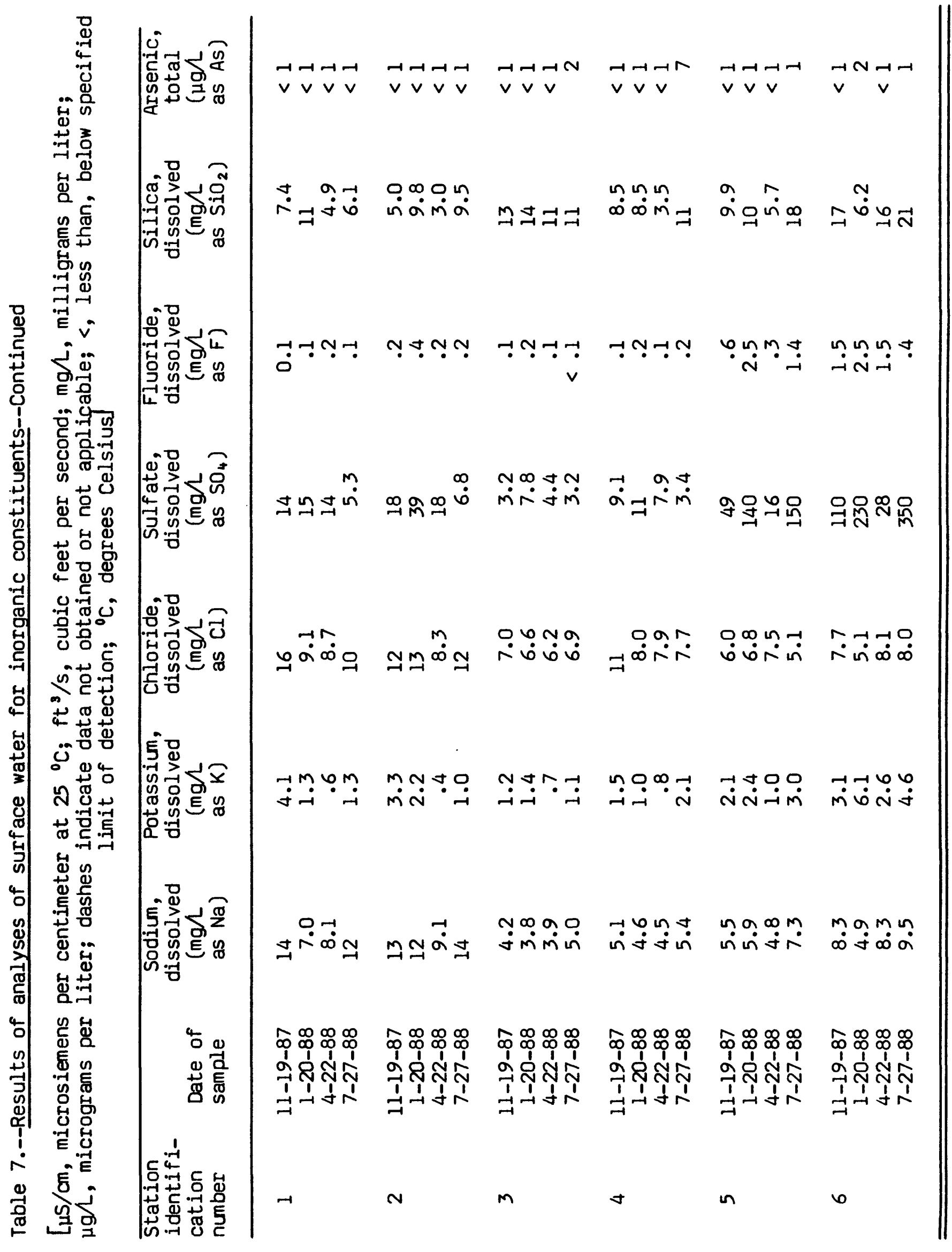




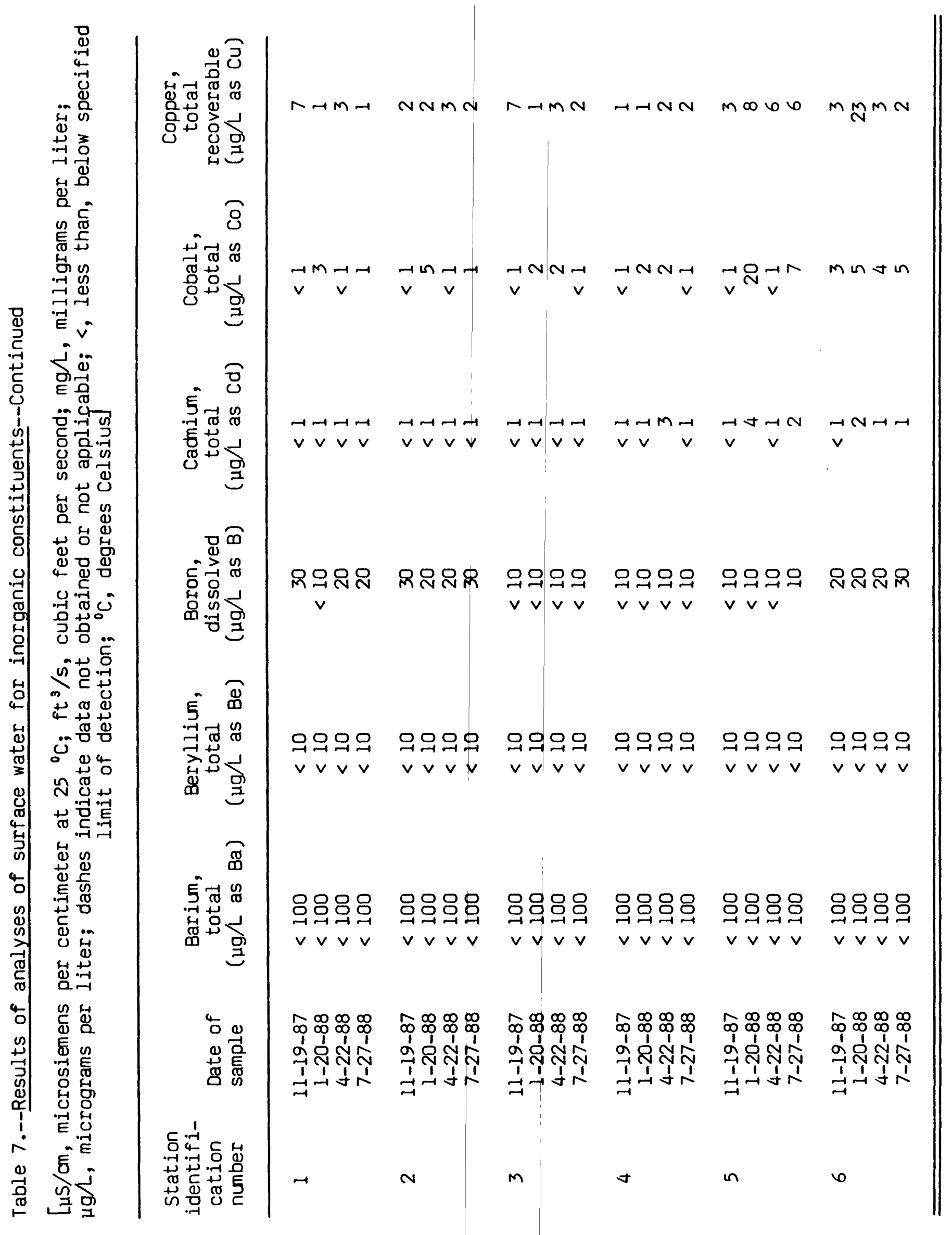




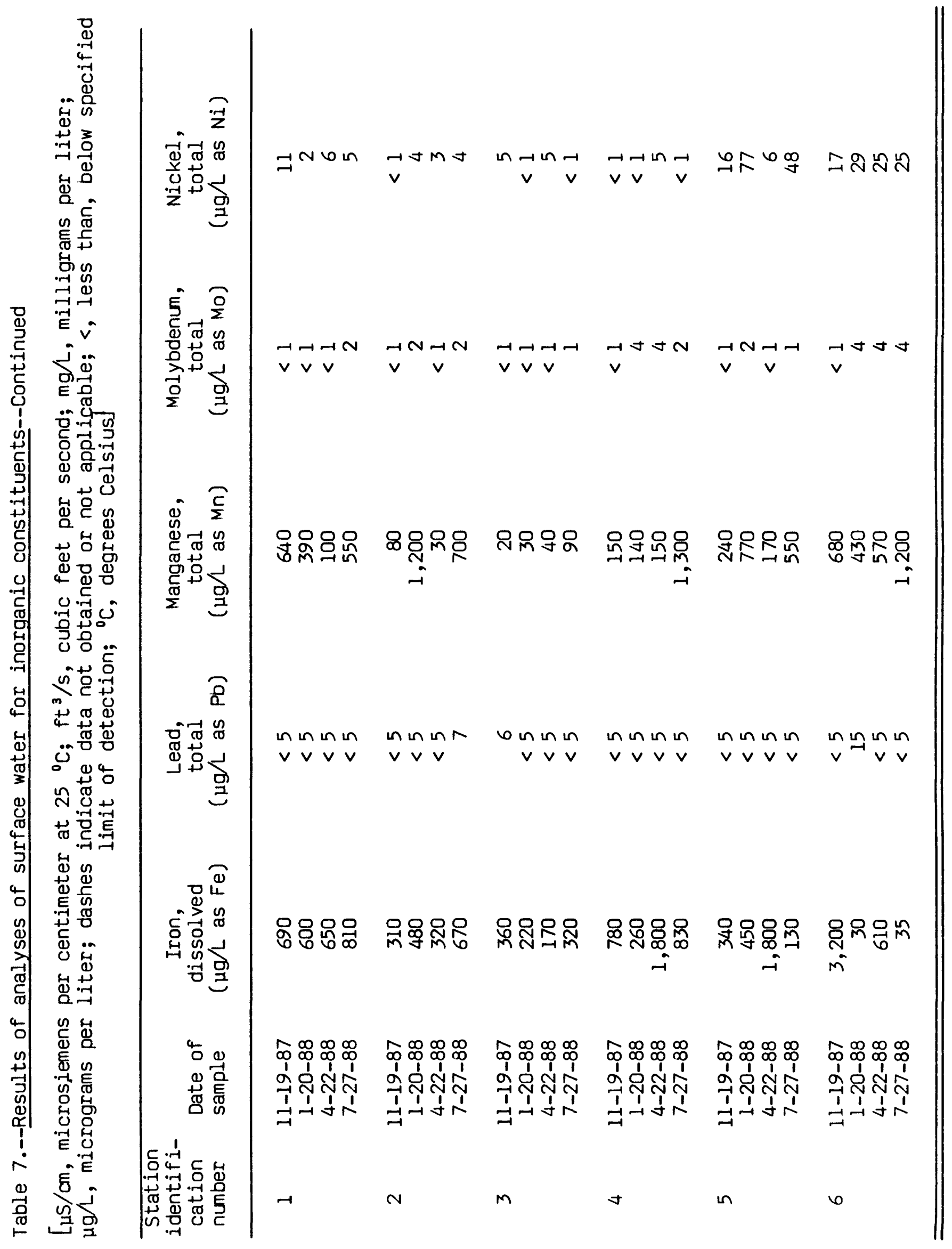




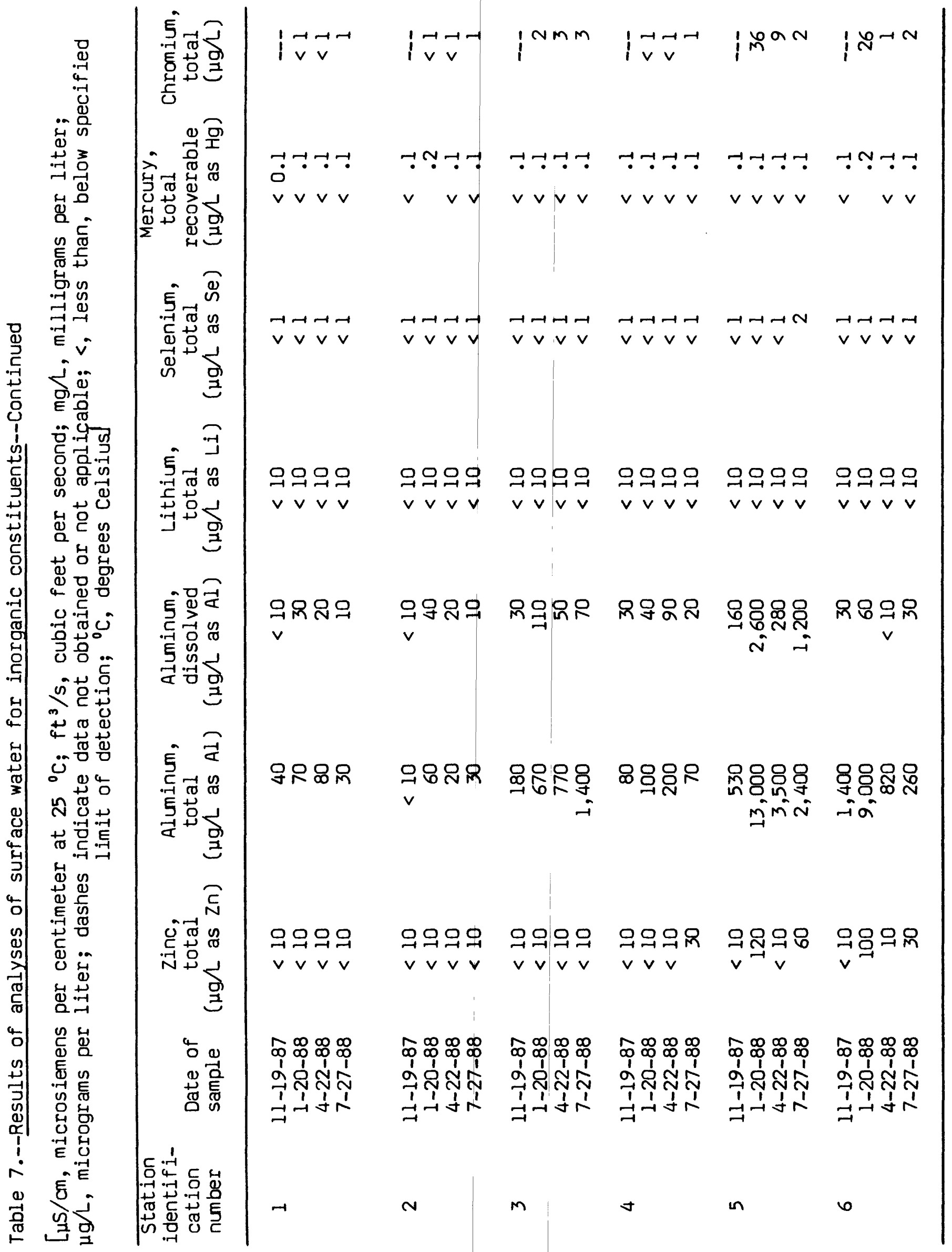


Table 8.--Results of analyses of surface water for purgeable organic compounds

$$
\text { [ug } \Lambda \text {, micrograms per liter] }
$$

\begin{tabular}{lcrc}
\hline $\begin{array}{l}\text { Station } \\
\text { number }\end{array}$ & $\begin{array}{c}\text { Station } \\
\text { identification } \\
\text { number }\end{array}$ & $\begin{array}{c}\text { Date of } \\
\text { sample }\end{array}$ & $\begin{array}{c}\text { Time } \\
\text { (hours) }\end{array}$ \\
\hline 02169861 & 1 & $11-19-87$ & 1545 \\
02169885 & 2 & $1-20-88$ & 1715 \\
02169860 & 3 & $11-19-87$ & 1000 \\
& & $1-20-88$ & 1600 \\
02169870 & 4 & $11-19-87$ & 0915 \\
& & $1-20-88$ & 1630 \\
02169875 & 5 & $11-19-87$ & 1400 \\
02169880 & 5 & $1-20-88$ & 1000 \\
& 5 & $11-19-87$ & 1255 \\
& 5 & $1-20-88$ & 1040 \\
\hline
\end{tabular}

Concentrations of all the purgeable organic compounds for which the samples were tested were below the detection limit of $3.0 \mu \mathrm{g} / \mathrm{L}$ total recoverable compound. These compounds included:

Dichlorobromomethane

Carbon tetrachloride

Dichlorodifluoromethane

Trichlorofluoromethane

Methylbromide

Methylchloride

Chlorodibromomethane

Chloroform

Bromoform

Methylene chloride

1,2-Dichloroethane

$1,1,1-$ Trichloroethane

$1,1,2-\operatorname{Tr}$ ichloroethane

$1,1,2,2-$ Tetrachloroethane

1,1-Dichloroethane

Chloroethane

Trichloroethylene

1,2-Dibromoethylene

vinyl chloride

1,2-trans-Dichloroethylene
Tetrachloroethylene

1,1-Dichloroethylene

2-Chloroethyl vinyl ether trans-1,3-Dichloropropene cis-1,3-Dichloropropene

1,3-Dichloropropane

1,2-Dichloropropane

Xylene

1,3-Dichlorobenzene

1,4-Dichlorobenzene

1,2-Dichlorobenzene

Chlorobenzene

Ethylbenzene

Toluene

Benzene

Styrene 
Table 9.--Results of analyses of surface water for acid-and base/ neutral-extractable

[ug/, micrograms per liter]

\begin{tabular}{lc|cc}
\hline $\begin{array}{l}\text { Station } \\
\text { number }\end{array}$ & $\begin{array}{c}\text { Station } \\
\text { identification } \\
\text { number }\end{array}$ & $\begin{array}{c}\text { Date of } \\
\text { sample }\end{array}$ & $\begin{array}{c}\text { Time } \\
\text { (hours) }\end{array}$ \\
\hline 02169861 & 1 & $\begin{array}{r}11-19-87 \\
1-20-88\end{array}$ & 1545 \\
02169885 & 2 & $11-29-87$ & 1715 \\
& & $1-20-88$ & 1000 \\
02169860 & 3 & $11-19-87$ & 1600 \\
02169870 & 4 & $1-20-88$ & 1000 \\
02169875 & 5 & $1-20-88$ & 0915 \\
02169880 & & $11-19-87$ & 1400 \\
& & $1-20-88$ & 1000 \\
\hline \hline
\end{tabular}

Concentrations of all the acid and base/heutral extractable organic compounds for which the samples were tested were below the detection limit for total recoverable compound, in $\mu \mathrm{g} / \mathrm{L}$, as shown in the following lists

\section{Compound}

Acenaphthylene Acenaphthene

Anthracene

Benzo (b) fluoranthene

Benzo (k) fluoranthene

Benzo (a) pyrene

bis (2-Chloroethyl) ether

bis (2-Chloroethoxy) methane

bis (2-Chloroisopropyl) ether

Butylbenzylphthalate

Chrysene

Diethylphthalate

Dimethylphthalate

Fluoranthene

Fluorene

Hexachlorocyclopentadiene

Hexachloroethane

Indeno $(1,2,3-C, D)$ pyrene

Isophorone

$\mathrm{N}$-nitroso-di-n-propylamine

$\mathrm{N}$-nitrosodiphenylamine

$\mathrm{N}$-nitroso-n-dimethylamine

Nitrobenzene

4-Chloro-3-methylphenol

Phenanthrene

Pyrene

Benzo $(\mathrm{g}, \mathrm{h}, \mathrm{i})$ perylene

Benz (a) anthracene

1,2-Dichlorobenzene

1,2,4-Trichlorobenzene
Detection

limit

5.0

5.0

5.0

10.0

10.0

10.0

5.0

5.0

5.0

5.0

10.0

5.0

5.0

5.0

5.0

5.0

5.0

10.0

5.0

5.0

5.0

5.0

5.0

30.0

5.0

5.0

10.0

5.0

5.0

5.0

\section{Compound}

Dibenz $(a, h)$ anthracene

1,3-Dichlorobenzene

1,4-Dichlorobenzene

2-Chloronaphthalene

2-Chlorophenol

2-Nitrophenol

Di-n-octylphthalate

2,4-Dichlorophenol

2,4-Dimethylphenol

2,4-Dinitrotoluene

2,4,6-Trichlorophenol

2,6-Dinitrotoluene

4-Bromophenyl phenyl ether

4-Chlorophenyl phenyl ether 4-Nitrophenol

Detection

4,6-Dinitro-2-methylphenol

Phenol

Naphthalene

Pentachlorophenol

Bis (2-ethylhexyl) phthalate

10.0

5.0

5.0

5.0

5.0

5.0

10.0

5.0

5.0

5.0

20.0

5.0

5.0

5.0

30.0

30.0

5.0

5.0

30.0

5.0

Di-n-butyl-phthalate

Hexachlorobenzene

5.0

Hexachlorobutadiene

5.0

2,4-Dinitrophenol

20.0 
Table 10.--Results of analyses of surface water for organochlorine compounds

[ug/, micrograms per liter]

\begin{tabular}{lcrl}
\hline $\begin{array}{l}\text { Station } \\
\text { number }\end{array}$ & $\begin{array}{c}\text { Station } \\
\text { identification } \\
\text { number }\end{array}$ & $\begin{array}{c}\text { Date of } \\
\text { sample }\end{array}$ & $\begin{array}{c}\text { Time } \\
\text { (hours) }\end{array}$ \\
\hline 02169861 & 1 & $\begin{array}{r}11-19-87 \\
1-20-88\end{array}$ & 1545 \\
02169885 & 2 & $\begin{array}{r}11-19-87 \\
1-20-88\end{array}$ & 1715 \\
02169860 & 3 & $11-19-87$ & 1000 \\
02169870 & 4 & $1-20-88$ & 1600 \\
02169875 & 4 & $11-19-87$ & 0915 \\
& & $1-20-88$ & 1630 \\
02169880 & 5 & $11-19-87$ & 1400 \\
& & $1-20-88$ & 1000 \\
& 6 & $11-19-87$ & 1255 \\
\hline
\end{tabular}

Concentrations of all the organochlorine compounds for which the samples were tested were below the detection limit for total recoverable compound, in $\mu \mathrm{g} /$. These compounds include:

\section{Compound}

Aldrin

Chlordane

DDO

DDE

DDT

Dieldrin

Endosulfan

Endrin

Gross polychlorinated biphenyls

Gross polychlorinated naphthalenes

Heptachlor

Heptachlor epoxide

Lindane

Methoxychlor

Mirex

Perthane

Toxaphene
Detection limit

0.01

.1

.01

.01

.01

.01

.01

.01

.1

.1

.01

.01

.01

.01

.01

1.1 


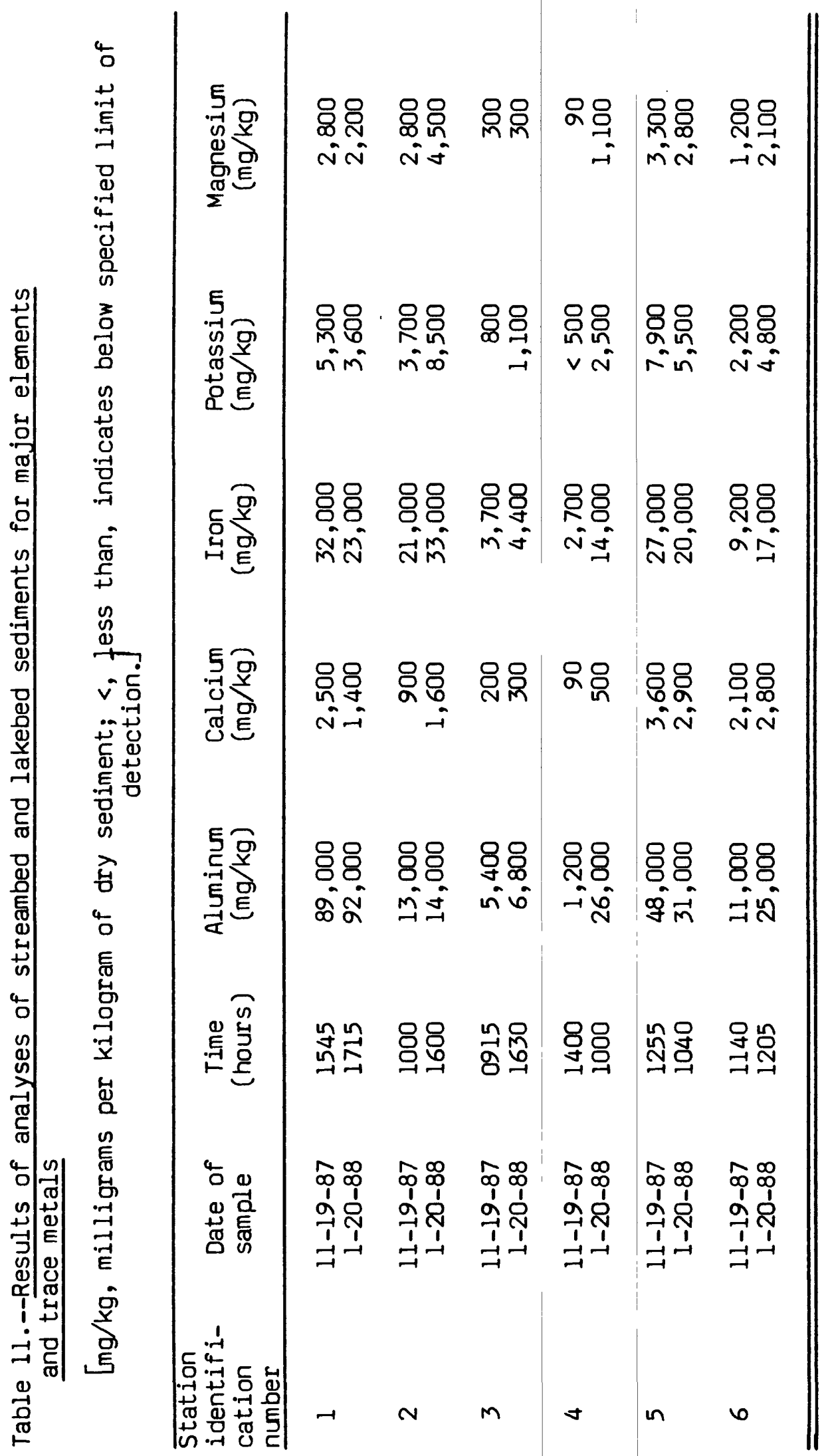




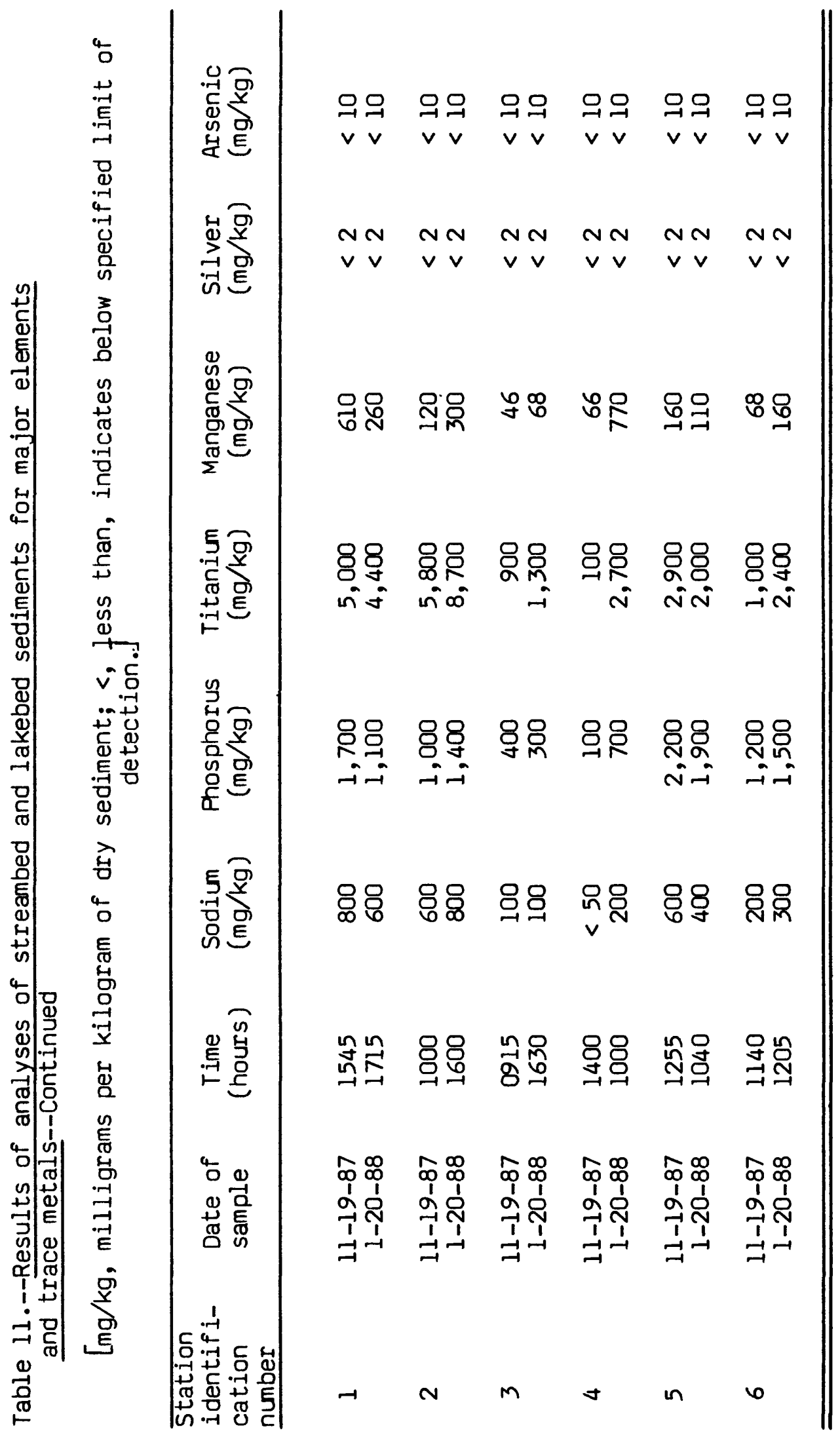




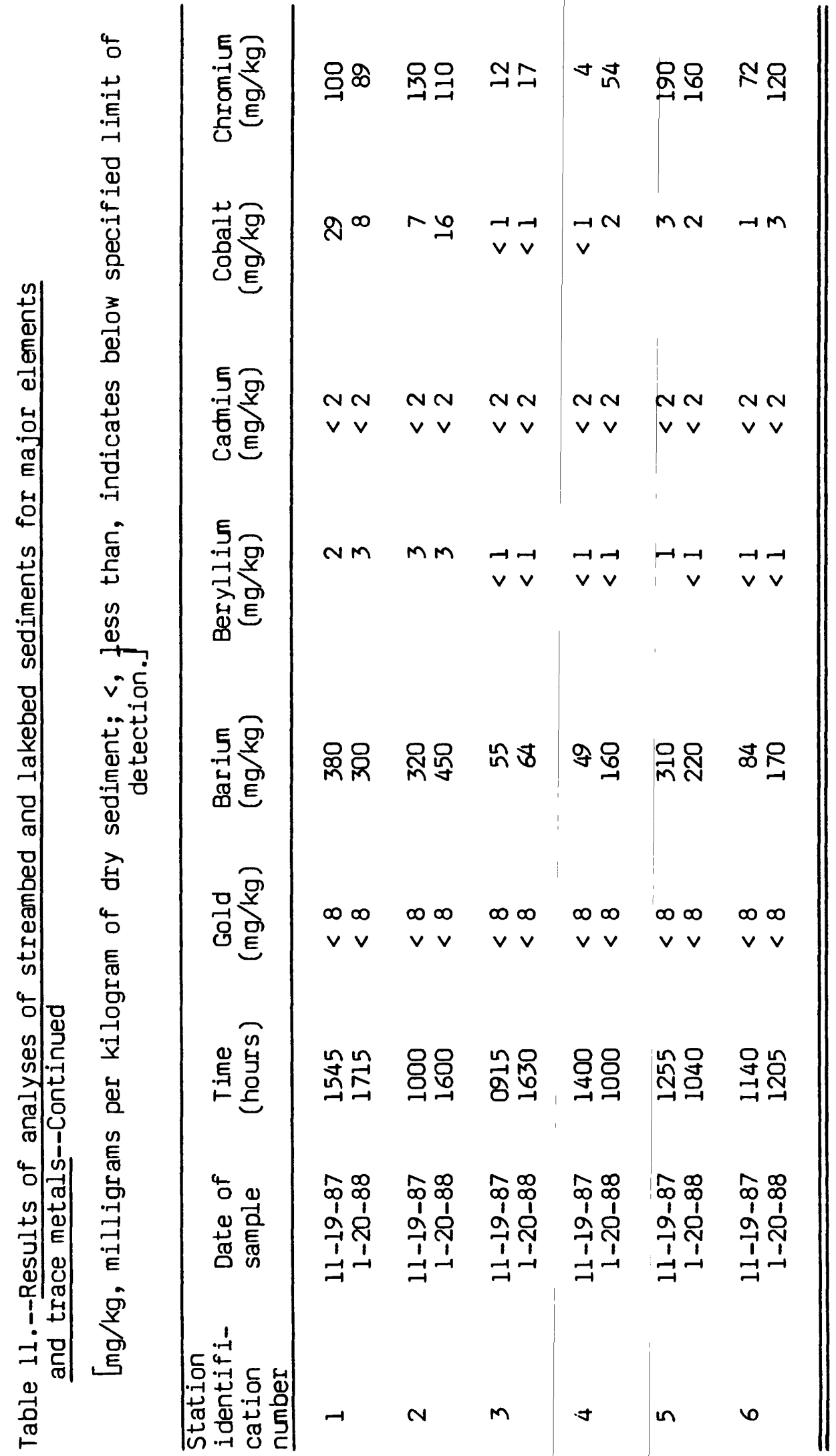




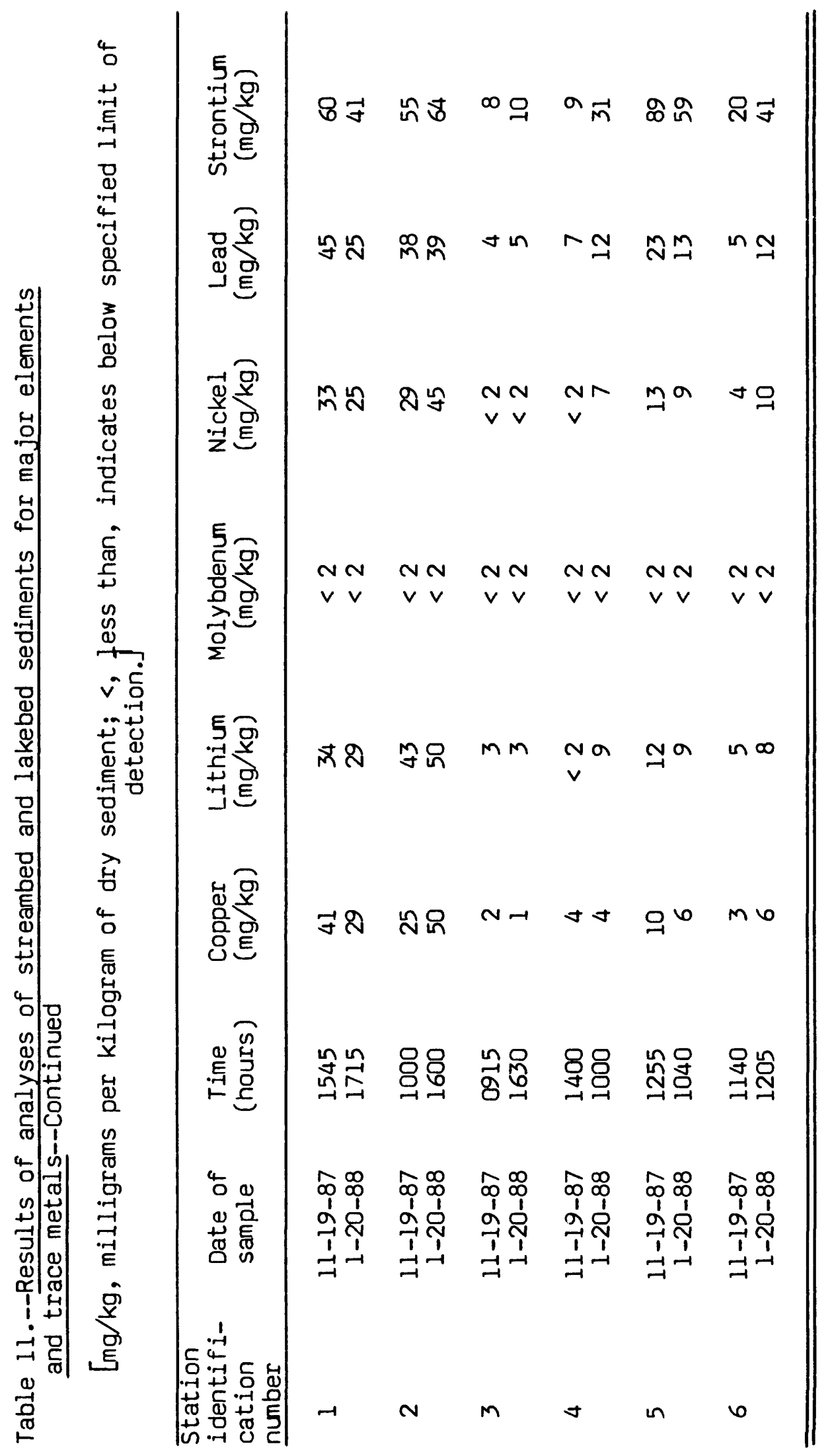




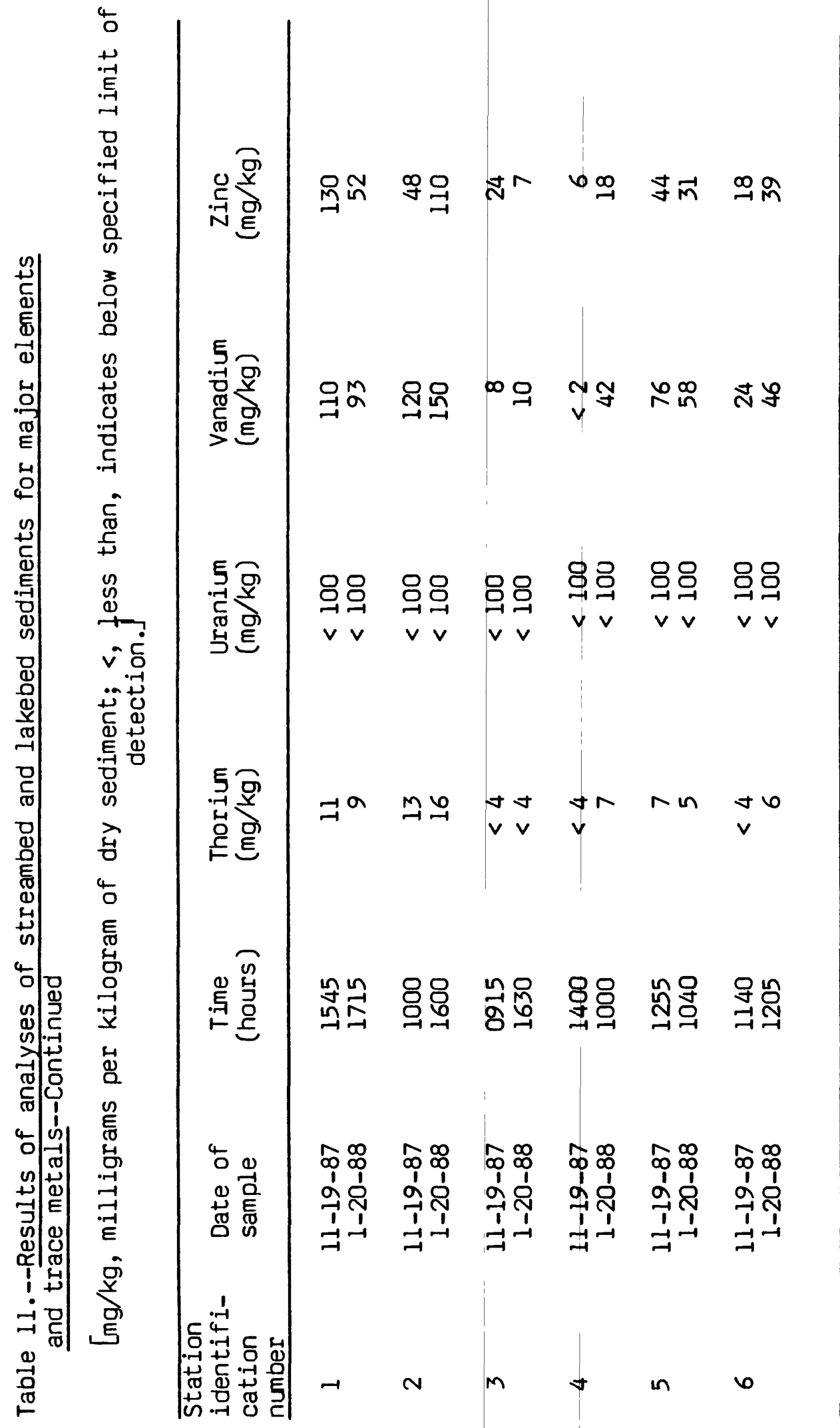


Table 12.--Results of analyses of streambed and lakebed sediments for acid and base/neutral extractable organic compounds

$[\mu \mathrm{g} / \mathrm{kg}$, micrograms per kilogram of dry sediment]

\begin{tabular}{lccc}
\hline $\begin{array}{l}\text { Station } \\
\text { number }\end{array}$ & $\begin{array}{c}\text { Station } \\
\text { identification } \\
\text { number }\end{array}$ & $\begin{array}{c}\text { Date of } \\
\text { sample }\end{array}$ & $\begin{array}{c}\text { Time } \\
\text { (hours) }\end{array}$ \\
\hline 02169861 & 1 & $11-19-87$ & $1-20-88$ \\
02169885 & 2 & $11-19-87$ & 1715 \\
02169860 & 3 & $1-20-88$ & 1000 \\
02169870 & 4 & $11-19-87$ & 1600 \\
02169875 & & $1-20-88$ & 0915 \\
& & $11-19-87$ & 1630 \\
02169880 & 5 & $1-20-88$ & 1400 \\
& & $11-19-87$ & 1000 \\
& 6 & $1-20-88$ & 1255 \\
& & $11-19-87$ & 1040 \\
\hline
\end{tabular}

\footnotetext{
Concentrations of all the acid and base/neutral extractable organic compounds for which the samples were tested were below the detection limit for total recoverable compound, in $\mu \mathrm{g} / \mathrm{kg}$, shown in the following list:
}

\begin{tabular}{|c|c|c|c|}
\hline Compound & $\frac{\text { Detection }}{\text { limit }}$ & Compound & $\frac{\text { tection }}{\text { Iimit }}$ \\
\hline Acenaphthylene & 200 & Dibenz $(a, h)$ anthracene & 400 \\
\hline Acenaphthene & 200 & 1,3-Dichlorobenzene & 200 \\
\hline Anthracene & 200 & 1,4-Dichlorobenzene & 200 \\
\hline Benzo (b) fluoranthene & 400 & 2-chloronaphthalene & 200 \\
\hline Benzo (k) fluoranthene & 400 & 2-Chlorophenol & 200 \\
\hline $\begin{array}{l}\text { Benzo (a) pyrene } \\
\text { bis (2-Chloroethyl ether } \\
\text { bis (2-Chloroethoxy) methane } \\
\text { bis (2-Chloroisopropyl) ether } \\
\text { Butylbenzylphthalate }\end{array}$ & $\begin{array}{l}400 \\
200 \\
200 \\
200 \\
200\end{array}$ & $\begin{array}{l}\text { 2-Nitrophenol } \\
\text { Di-n-octylphthalate } \\
\text { 2,4-Dichlorophenol } \\
\text { 2,4-Dimethylphenol } \\
\text { 2,4-Dinitrotoluene }\end{array}$ & $\begin{array}{l}200 \\
400 \\
200 \\
200 \\
200\end{array}$ \\
\hline $\begin{array}{l}\text { Chrysene } \\
\text { Diethytlphthalate } \\
\text { Dimethylphthalate } \\
\text { Fluoranthene } \\
\text { Fluorene }\end{array}$ & $\begin{array}{l}400 \\
200 \\
200 \\
200 \\
200\end{array}$ & $\begin{array}{l}\text { 2,4,6-Trichlorophenol } \\
\text { 2,6-Dinitrotoluene } \\
\text { 4-Bromophenyl phenyl ether } \\
\text { 4-Chlorophenyl phenyl ether } \\
\text { 4-Nitrophenol }\end{array}$ & $\begin{array}{l}600 \\
200 \\
200 \\
200 \\
600\end{array}$ \\
\hline $\begin{array}{l}\text { Hexachlorocyclopentadiene } \\
\text { Hexachloroethane } \\
\text { Indeno }(1,2,3-C, D) \text { pyrene } \\
\text { Isophorone } \\
\text { N-nitroso-di-n-propylamine }\end{array}$ & $\begin{array}{l}200 \\
200 \\
400 \\
200 \\
200\end{array}$ & $\begin{array}{l}\text { 4,6-Dinitro-2-methylphenol } \\
\text { Phenol } \\
\text { Naphthalene } \\
\text { Pentachlorophenol } \\
\text { Bis (2-ethylhexyl) phthalate }\end{array}$ & $\begin{array}{l}600 \\
200 \\
200 \\
600 \\
200\end{array}$ \\
\hline $\begin{array}{l}\text { N-nitroso-di-phenylamine } \\
\text { N-nitroso-n-dimethylamine } \\
\text { Nitrobenzene } \\
\text { 4-Chloro-3-methylphenol } \\
\text { Phenanthrene }\end{array}$ & $\begin{array}{l}200 \\
200 \\
200 \\
600 \\
200\end{array}$ & $\begin{array}{l}\text { Di-n-butyl-phthalate } \\
\text { Hexachlorobenzene } \\
\text { Hexachlorobutadiene } \\
\text { 2,4-Dinitrophenol }\end{array}$ & $\begin{array}{l}200 \\
200 \\
200 \\
600\end{array}$ \\
\hline $\begin{array}{l}\text { Pyrene } \\
\text { Benzo (g,h,i) perylene } \\
\text { Benz(a) anthracene } \\
1,2-D i c h l o r o b e n z e n e \\
1,2,4-T r \text { ichlorobenzene }\end{array}$ & $\begin{array}{l}200 \\
400 \\
400 \\
200 \\
200\end{array}$ & & \\
\hline
\end{tabular}




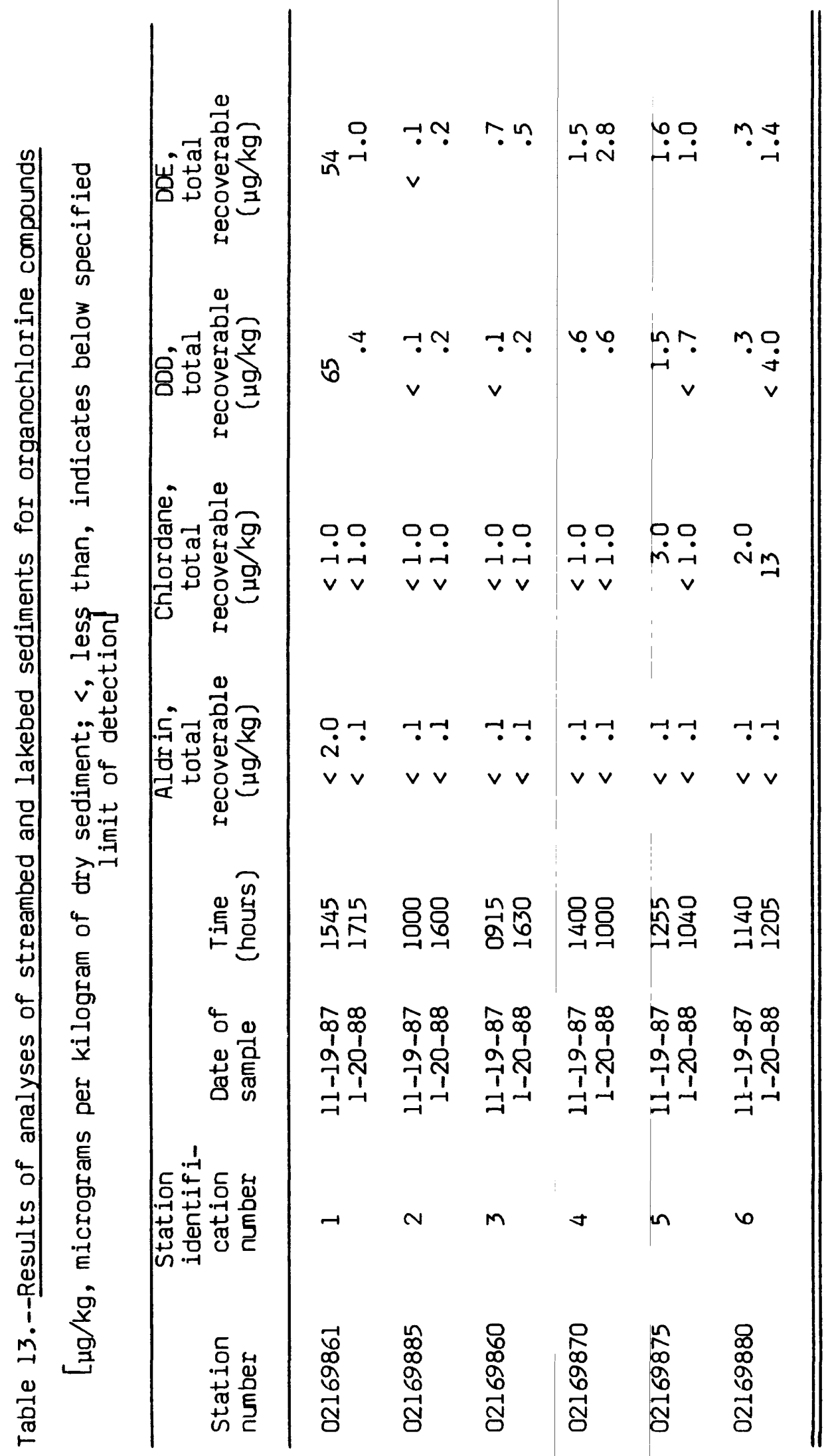




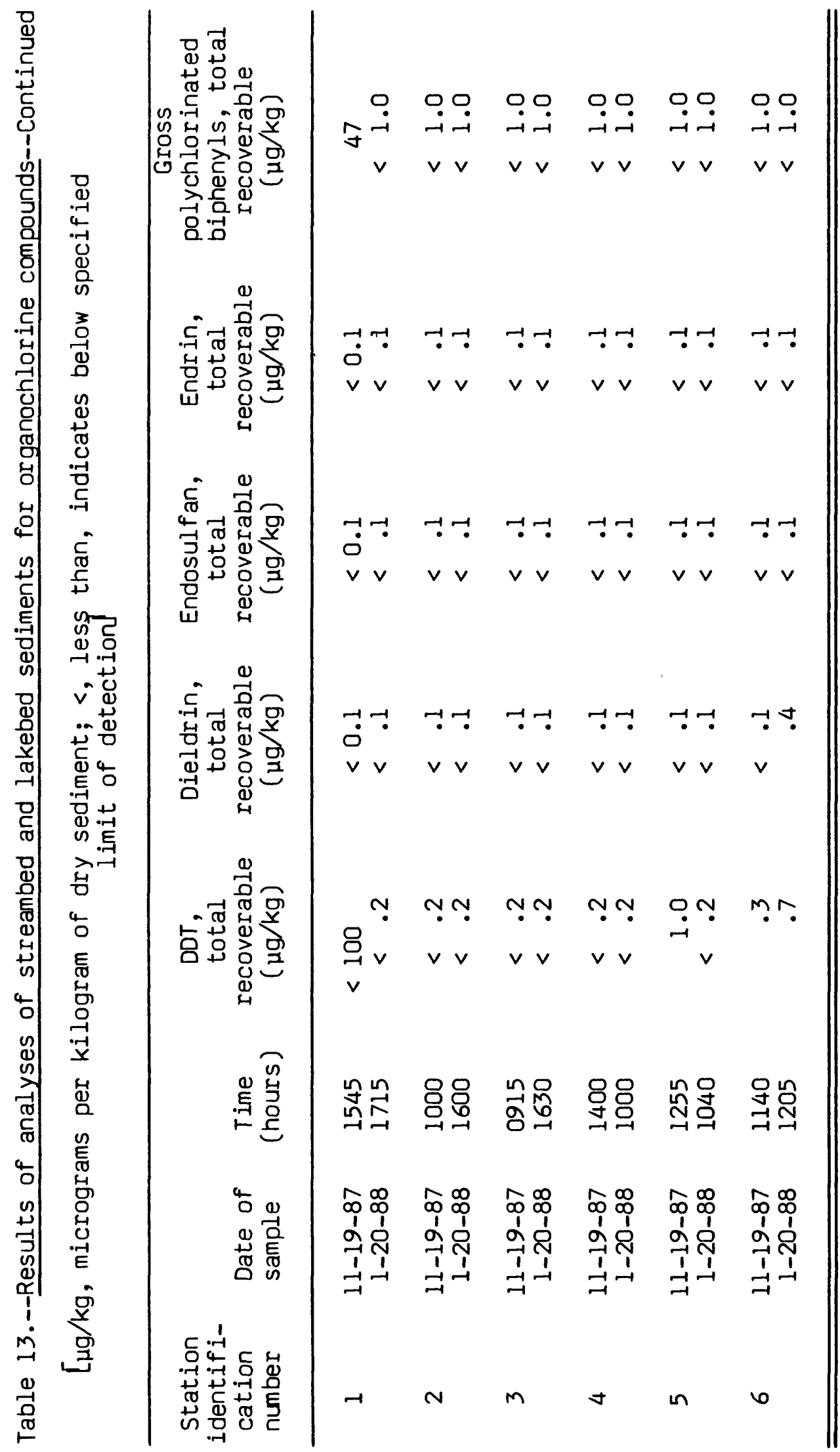




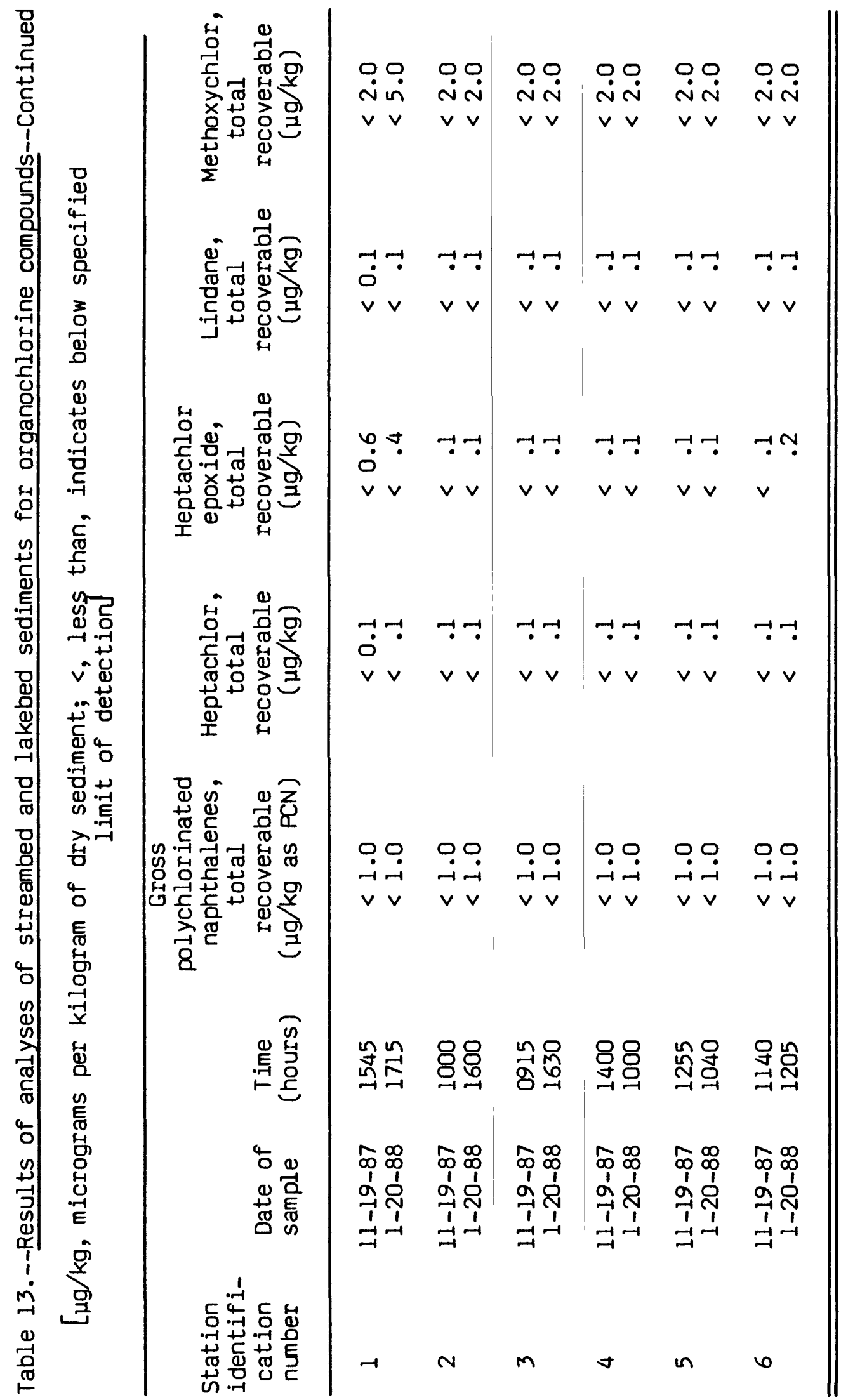




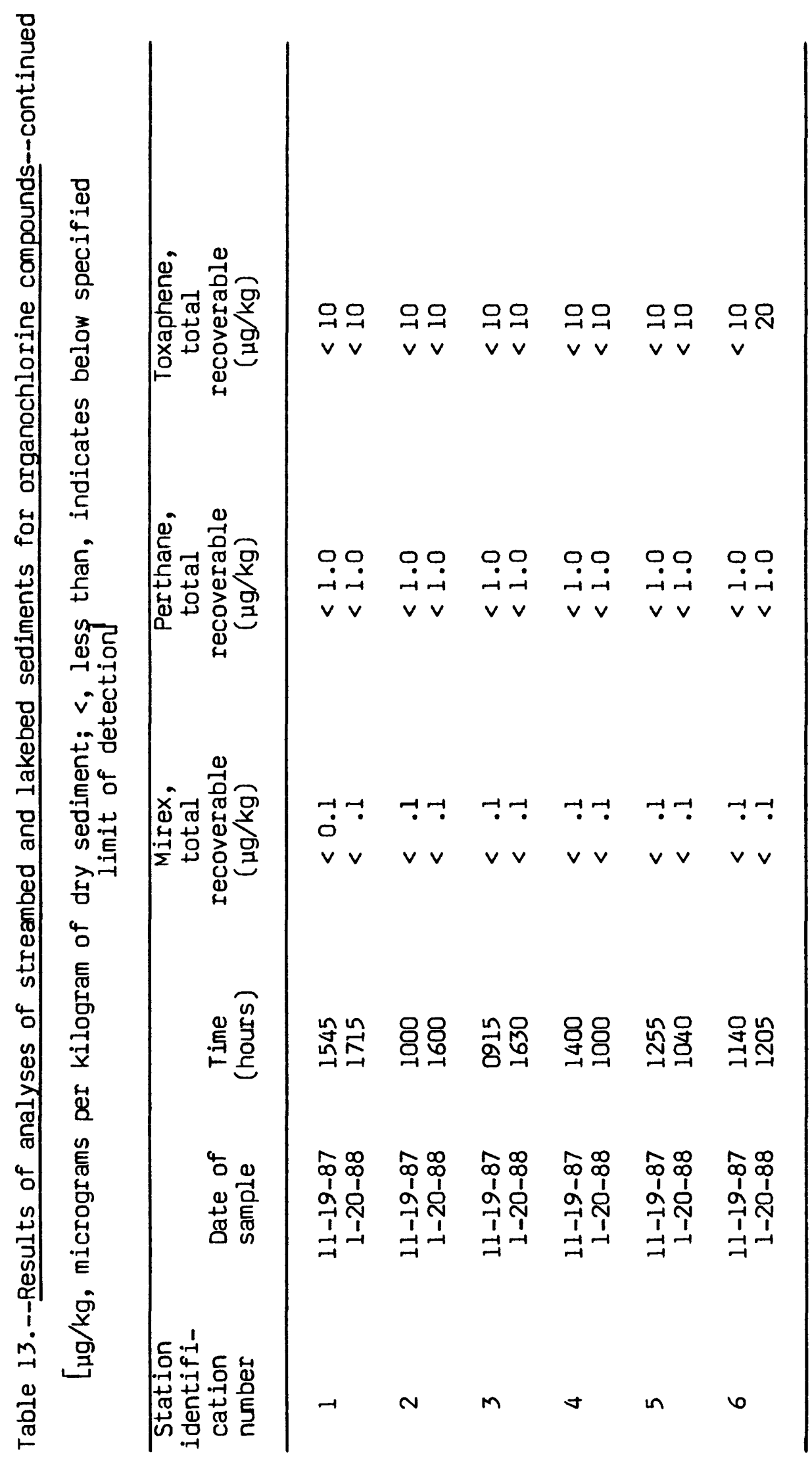




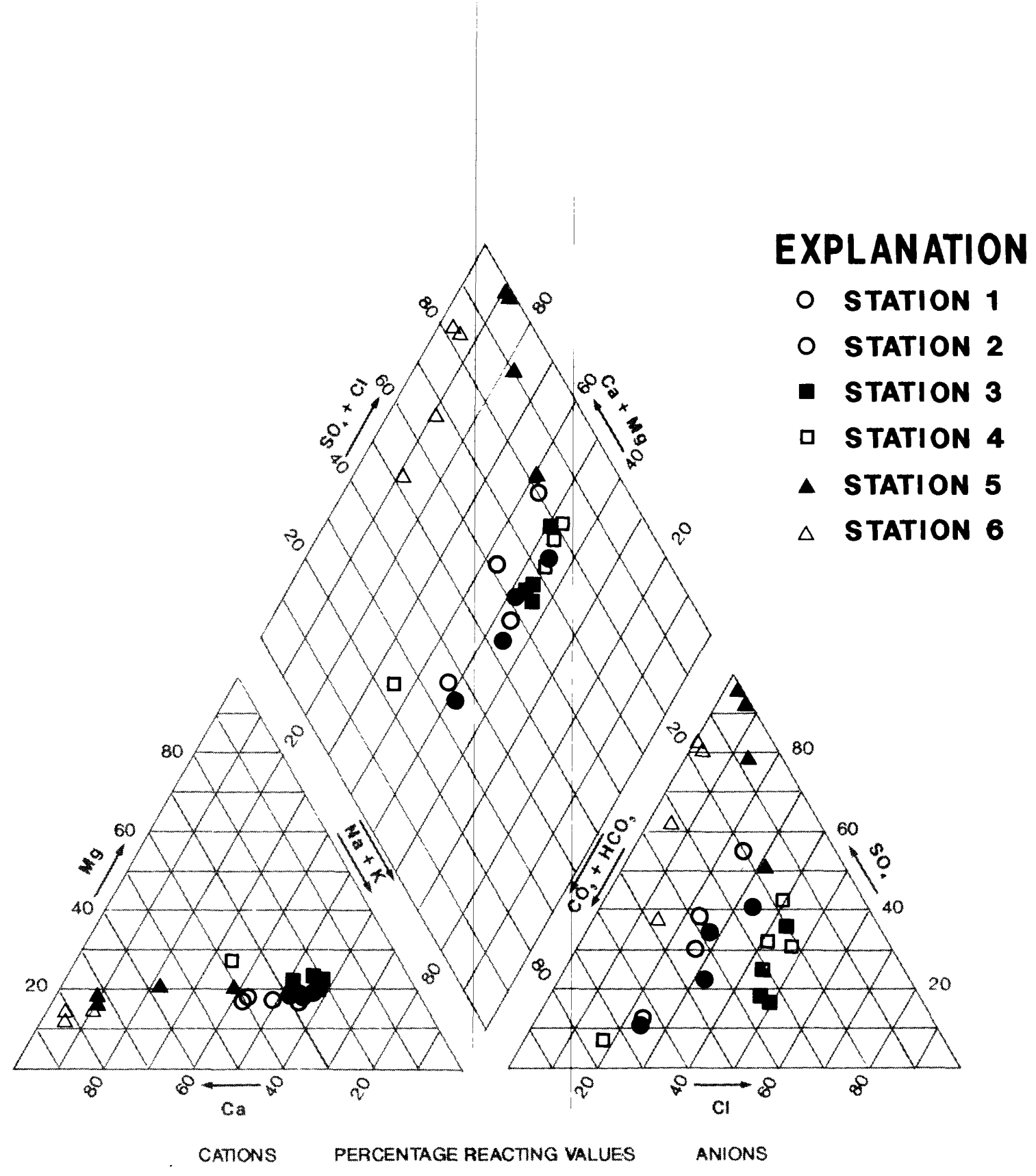

Figure 41.--Chemical analyses of water from stations 1 through 6 . 
The differences in $\mathrm{pH}$ and in concentrations of calcium, sulfate, and alkalinity in water from stations 5 and 6 as compared to those in water from stations 3 and 4 may be caused by earth-moving activities at the landfill. sites 5 and 6 receive drainage from spoil piles located along the western boundary of the landfill. The spoils consist of material excavated during construction of disposal pits and include surficial sediments and claystone. Visual inspection of the spoil piles and trench walls showed that the claystone contained abundant pyrite. Oxidation of pyrite in spoil material is known to produce sulfate and acid (Drever, 1982, p. 62) and may be summarized by the general equation,

$$
4 \mathrm{FeS}_{2}+15 \mathrm{O}_{2}+14 \mathrm{H}_{2} \mathrm{O}+4 \mathrm{Fe}(\mathrm{OH})_{3}+16 \mathrm{H}^{+}+8 \mathrm{SO}_{4}=.
$$

It is likely that the relatively high concentrations of dissolved sulfate measured at stations 5 and 6 , and the low pH measured at station 5 , are a result of the oxidation of pyrite in the spoil piles and subsequent leaching of that material to the streams and shallow ground water that discharges to the streams. This conclusion is supported by water-quality data obtained from two water-table wells located at the base of the bluff near the western edge of the landfill site (fig. 2). The well designated Lake Marion 2B is located between station 5 and station 6 and downgradient from the spoil piles. The well designated Rimini $1 E$ is located about 1 mile from the site and therefore is probably not significantly influenced by the spoil piles. Well Rimini IE had measured values of $\mathrm{pH}$ and dissolved sulfate of 6.52 and $<0.1 \mathrm{mg} / \mathrm{L}$, respectively. In contrast, well Lake Marion 2B had measured $\mathrm{pH}$ and dissolved sulfate of $4.27 \mathrm{pH}$ units and $382 \mathrm{mg} / \mathrm{h}$, which indicates that there is a source of acid and sulfate in the vicinity of this well.

The fact that water at station 6 is high in dissolved sulfate and alkalinity indicates that this stream has a greater source of alkalinity, which serves as a buffer against changes in pH, than does the stream at station 5. Potential sources of alkalinity include the old sedimentation pond drained by the stream and dissolution of partially silicified shell material in the spoil piles. Dissolution of carbonate shell material produces calcium and alkalinity in the form of bicarbonate; and can be summarized by the general equation

$$
\mathrm{CaCO}_{3}+\mathrm{H}^{+} \rightarrow \mathrm{Ca}^{++}+\mathrm{HCO}_{3}^{-} \cdot
$$

Assuming that the source of alkalinity is calcite dissolution, differences in alkalinity and pH between stations 5 and 6 can be explained by differences in the amount of calcite dissolved (reaction 2) and pyrite oxidized (reaction 1) at the two stations. For example, calcite dissolution and pyrite oxidation in the molar ratio 2.3-to-1.0 would produce the molar ratio of dissolved calcium to dissolved sulfate measured at station 6 . In contrast, calcite dissolution and pyrite oxidation in the ratio 1.5-to-1.0 would produce the molar ratio measured at station 5 . Additional calcite dissolution at station 6 could increase alkalinity and pH over that produced at station 5 . 
Although these data indicated that pyrite oxidation in the spoil piles contributes acidity and dissolved sulfate to the streams and shallow ground water, there was no detectable difference ( 0.05 level of significance) in the measured values of $\mathrm{pH}$ or sulfate between station 2, located in the lake downstream of stations 5 and 6 , and station 1 , representing background conditions in the lake. Except for slightly elevated concentrations of calcium at station 2 (ranging from 7.0 to $11 \mathrm{mg} / \mathrm{L}$ ) relative to station 1 (ranging from 3.6 to $6.8 \mathrm{mg} /$ ), the data indicated no significant differences in the concentrations of major inorganic constituents between the two lake sampling stations. The similarity of results for the two lake stations could reflect the fact that only a small fraction of the lake water is derived from the small streams in the study area.

Measured concentrations of nutrients in the water were generally small, with only one value exceeding $1.0 \mathrm{mg} /$. The sample collected at station 5 on January 20,1988 , contained $1.24 \mathrm{mg} / \mathrm{L}$ of total phosphorus.

The majority of the concentrations of trace metals in water were below the levels of analytical detection, as indicated in table 7 . Copper (total recoverable), iron (dissolved), and manganese (total) were the only trace elements measured at detectable levels consistently at each site for every sampling period. Water at stations 5 and 6 generally exhibited the highest measured concentrations of trace elements (tables 6 and 7). For example, the maximum measured concentration of zinc (total) was $120 \mu \mathrm{g} / \mathrm{L}$ at station 5, compared with less than $10 \mu \mathrm{g} /$ at stations 1 through 4; the maximum measured concentration of nickel (total) was $48 \mu \mathrm{g} /$ at station 5 , compared with $11 \mu \mathrm{g} /$ at stations 1 through 4; and the highest concentration of chromium (total) was $36 \mu \mathrm{g} /$ at station 5 , compared with $3 \mu \mathrm{g} /$ at stations 1 through 4 . Because of the number of analyses below detection limits, the statistical significance of these differences was not determined. The highest concentrations of many metals were detected at stations 5 and 6 during the high-flow sampling period in January, indicating that runoff from the site contributed trace elements to these streams, or that bed sediments containing trace elements were being transported during storm events. No significant differences in trace-element concentration ranges seem to exist between the background lake station (station 1) and station 2, which is the lake station within the influence of runoff from the landfill, again indicating that runoff from the small streams in the study area has little effect on the lake chemistry.

The concentrations of inorganic constituents detected in surface water in the vicinity of the landfill generally are indicative of uncontaminated waters although there is evidence that earth-moving activities at the landfill have affected the quality of water at stations 5 and 6 to some degree. Comparison of the water-quality data in table 7 with the National Water Quality Criteria for aquatic life (U.S. Enviromental Protection Agency, 1986) shows that inorganic constituents in the water exceeded recommended limits in only a few instances. For example, the measured concentration of copper at station 3 in November 1987 was $7 \mu \mathrm{g} /$ compared to the recommended 1 -hour average concentration of $2 \mu \mathrm{g} /$, for the total hardness measured that day. It should be noted that the measured value for copper is for a single point in time; therefore, comparing this with 
time-averaged values should be done with caution. The concentrations of iron at stations 4,5 , and 6 also exceeded the $1 \mathrm{mg} / \mathrm{L}$ recommended 1 imit during three sampling periods (table 7). Finally, 14 measured values of pH were below the criterion of 6.5 - 9.0 for freshwater aquatic life. This by itself is not critical because the primary effect of low pH is to increase the solubility of other compounds and, as previously discussed, concentrations of most other inorganic constituents in the water were below critical levels.

\section{Organic Constituents in Water}

None of the organic compounds for which surface-water samples were tested were found in concentrations exceeding the specified analytical limits of detection during either the low-flow or high-flow sampling periods (tables 8, 9, and 10). During low-flow periods ground water is the primary source of water to the streams. The lack of organic contaminants in the stream water during low-flow periods indicates that no detectable source of contaminated ground-water discharge exists. The lack of organic contaminants in the stream water during high-flow periods, when runoff is the primary contribution to streamflow, indicates that no detectable organic contaminants are being transported by surface runoff in the drainage areas.

\section{Inorganic Constituents in Bottom Sediment}

Data on concentrations of major elements, and the more environmentally significant trace elements in lakebed and streambed sediments, are given in table 10 and are summarized in table 6. Lakebed sediments at stations 1 and 2 generally contained greater concentrations of trace elements than those in the streambed sediments, as with beryllium, cobalt, copper, lithium, nickel, lead, zinc. This is not surprising because lakebed sediments act as sinks for river-transported trace elements in both the aqueous and solid phases. The fact that stations 5 and 6 generally had greater measured concentrations of chromium, nickel, vanadium, and zinc than were measured at stations 3 and 4 indicates that trace element concentrations in the streambed sediments could be influenced by activities in the respective drainage areas that include the landfill. As previously discussed, concentrations of trace elements in the combined aqueous and suspended-solid phases also were greater at stations 5 and 6 than at stations 3 and 4 , suggesting a similar conclusion.

\section{Organic Constituents in Bottom Sediment}

The one acid- or base/neutral-extractable compound found in detectable concentrations in sediments was phenol which was detected at station 4 , upstream from the landfill. The concentration of phenol in sediment collected from station 4 in November was $7,900 \mu \mathrm{g} / \mathrm{kg}$ and the concentration in sediment collected in January was $260 \mu \mathrm{g} / \mathrm{kg}$ (table 12). The fact that less phenol was found in the sediment during high-flow conditions indicates that some of the phenol-containing material may have been mobilized by the higher velocity conditions in January. The analysis for phenol in the 
surface-water samples, however, showed no detectable concentrations for November or January. The difference in concentrations may therefore reflect the fact that sediment samples were not collected along exactly the same channel cross section during November and January, or it may indicate that the bed sediments had been redistributed during an intervening storm. In any event, the observation that no phenol was found in sediments or water downstream at station 5 or in the water at station 4 indicates that this compound is not widely distributed in this system. No readily apparent source of phenol was found in the vicinity of station 4.

Organochlorine compounds were detected in bed sediments from stream and lake sites (tables 6 and 13). The compounds DDD and DDE were detected at all sites, but the greatest variety and concentrations of organochlorine compounds occurred at stations 1, 5, and 6. Concentrations of DDD, DDE, and PCB exceeded $45 \mu \mathrm{g} / \mathrm{kg}$ at station $\mathrm{l}$, which is in the lake upstream of the landfill. Note that due to interference from other compounds in the sample (most notably PCB), the measured concentration of DDT in the November sample from station 1 could not be quantified other than determining its concentration to be less than $100 \mu \mathrm{g} / \mathrm{kg}$. Chlordane was detected exclusively at station 5 and 6 , which are downstream of the landfill; dieldrin and toxaphene were detected exclusively at station 6 .

Because of the widespread use of organochlorine compounds as pesticides in the past, their affinity for the solid phase, and their persistence, it is not unusual to find these compounds in surficial sediments. The compounds detected at stations 1 through 6 do not appear to be appreciably mobile in this system, as evidenced by the flact that none of them were detected in samples of surface water.

\section{SUMMARY AND CONCLUSIONS}

As part of a 3-year study of the surface-water and ground-water systems in the vicinity of a hazardous-waste landfill near Pinewood, S.C., the streamflow characteristics, lake-flow patterns, rainfall, water quality, and sediment composition of the area were investigated. The data and interpretations characterize natural background conditions during parts of the period from March 1987 to January 1989 and compare background conditions with those in areas influenced by runoff from the landfill. The primary purpose of this phase of the study was to establish a data base with which future data can be compared to evaluate environmental effects.

Seven permanent stations were located in the study area for collection of streamflow and rainfall data, water-quality samples, and sediment samples. Two of the stations are located in Lake Marion, a large reservoir that lies within 1,200 ft of the landfill; the remaining stations are on streams that discharge to Lake Marion. One lake station and two stream stations are background stations with regard to the landfill site because they lie outside the influence of runoff from the landfill site. The other lake station and two stream stations are located in areas influenced by runoff from the site. A rain gage was operated on the landfill site. 
As part of dye tracer tests in Lake Marion, an additional 35 temporary stations were located in the lake to monitor flow patterns within the lake in the vicinity of the landfill. The spread of fluorescent dye, injected near the mouths of streams discharging from the landfill under both high-flow and low-flow conditions to simulate potential contaminant discharges from the site, demonstrated that discharge from the landfill area tends to flow southeastward in the lake, hugging the eastern shore.

Streamflow records collected at the 4 stream stations on 3 small streams with drainage areas of $0.066,1.635$, and $0.395 \mathrm{mi}^{2}$ indicate that instantaneous flows ranged from 0.00 to $9.8 \mathrm{ft}^{3} / \mathrm{s}$ and monthly mean flows ranged from 0.00 to $1.7 \mathrm{ft}^{3} / \mathrm{s}$ during the study. Annual mean flows at three of the stream stations were $0.08,0.69$ and $0.41 \mathrm{ft}^{3} / \mathrm{s}_{3}$ Baseflows in the streams ranged from 0.00 to $1.0 \mathrm{ft}^{3} / \mathrm{s}\left[0.00\right.$ to $\left.1.5\left(\mathrm{ft}^{3} / \mathrm{s}\right) / \mathrm{mi}^{2}\right]$.

During 1988, rainfall at the landfill was 34.9 inches, compared to an average annual rainfall of 46 inches. Minimum monthly rainfall was 0.72 inch in June, and maximum monthly rainfall was 6.22 inches in September.

The chemical quality of surface water and sediment in the vicinity of the landfill generally is indicative of uncontaminated water. Significant differences in inorganic chemistry between background stream stations and stream stations within the influence of the landfill were identified and indicated that land use, primarily earth-moving operations at the landfill, may be affecting the streams. Effects of landfill operation generally were not significant at the lake sites. The primary differences observed at the stream sites were increases over background levels of calcium and sulfate, lower pH values in the water of some stream reaches, and increased concentrations of some trace metals in the water and sediment. The increased concentrations were small and generally resulted in concentrations well below U.S. Environmental Protection Agency water-quality criteria. The elevated concentrations of sulfate, and associated low pH values, probably are the result of oxidizing pyrite in spoil piles on the landfill. The source of high calcium concentrations at one site could be carbonate minerals in partially silicified shell material in the spoil piles.

Anthropogenic organic compounds, including phenol and organochlorine compounds, were detected in sediment at the stream sites and lake sites. These generally were as prevalent at background sites as at sites within the influence of the landfill; therefore, the landfill does not seem to be their source. No detectable concentrations of anthropogenic organic compounds were found in the surface water. 


\section{REFERENCES}

American Public Health Association, 1981, Standard methods for the examination of water and wastewater: Franson, M.A.H. (ed.), American Public Health Association, $1134 \mathrm{p}$.

Aware, Inc., 1985a, Draft groundwater assessment - supplemental hydrogeologic investigation: Prepared for GSX Services of South Carolina, Inc., Pinewood, S.C., 3 vols.

----- 1985b, Ground-water assessment plan - Pinewood Facility, June 6, 1985: Prepared for GSX Services of South Carolina, Inc., Pinewood, S.C.

---- 1985c, Draft groundwater monitoring plan: Prepared for GSX Services of South Carolina, Inc., Pinewood, S.C.

---- 1985d, Additional hydrogeologic data - GSX Services of South Carolina, Pinewood Facility: Prepared for GSX Services of South Carolina, Inc., Pinewood, S.C.

1985e, Groundwater assessment report - Pinewood Facility: Prepared for GSX Services of South Carolina, Inc., Pinewood, S.C.

1985f, Phase IV hydrogeologic report: Prepared for GSX Services of South Carolina, Inc., Pinewood, S.C.

$1985 \mathrm{~g}$, Groundwater assessment - supplemental hydrogeologic investigations:

Prepared for GSX Services of South Carolina, Inc., Pinewood, S.C. v. 4

Bodhaine, G.L., 1968, Measurement of peak discharge at culverts by indirect methods: U.S. Geological Survey Techniques of Water-Resources Investigations $3-A 3,60 \mathrm{p}$.

Buchanan, T.J., and Somers, W.P., 1968, Stage measurements of gaging stations: U.S. Geological Survey Techniques of Water-Resources Investigations $3-A 7,28$ p.

Buchanan, T.J., and Somers, W.P., 1969, Discharge measurements at gaging stations: U.S. Geological Survey Techniques of Water-Resources Investigations $3-A 8,65 \mathrm{p}$.

Carter, R.W., and Davidian, J., 1968, General procedure for gaging streams, U.S. Geological Survey Techniques of Water-Resources Investigations 3-A6, $13 \mathrm{p}$.

Cook, C.W., 1936, Geology of the coastal plain of South Carolina: U.S. Geological Survey Bulletin 867, $196 \mathrm{p}$.

Drever, J.I., 1982, The geochemistry of natural waters: Prentice-Hall, Inc., Inglewood Cliffs, N.J., 388 p.

EBASCO Services Incorporated, 1986, A study of the enviromental characteristics of the hazardous waste land disposal facility at Pinewood, South Carolina: Prepared for the State of South Carolina Budget and Control Board, Division of General Services, 191 p. 


\section{REFERENCES--Continued}

Environmental Technology Engineering, Inc., 1987, Part B permit application, revision no. 5: Prepared for GSX Services of South Carolina, Inc., Pinewood, S.C., 123 p.

Fishman, M.J., and Friedman, L.C., 1985, Methods for determination of inorganic substances in water and fluvial sediments: U.S. Geological Survey Techniques of Water-Resources Investigations 5-Al, 626 p.,

Hulsing, Harry., 1967, Measurement of peak discharge at dams by indirect methods: U.S. Geological Survey Techniques of Water-Resources Investigations $3-A 5,29 \mathrm{p}$.

Inabinet, J.R., 1985, Water quality characteristics of the Santee-Cooper Lake system: Santee Cooper Environmental Resources Division, Water Quality Management Section, Moncks Corner, S.C., 94 p.

Kennedy, E.J., 1983, Computation of continuous records of streamflow: U.S. Geological Survey Techniques of Water-Resources Investigations 3-A6, 53 p.

----- 1984, Discharge ratings at gaging stations U.S. Geological Survey Techniques of Water-Resources Investigations 3-AlO, $59 \mathrm{p}$.

Park, A.D., 1980, The ground-water resources of Sumter and Florence Counties, South Carolina: South Carolina Water Resources Commission Report No. 133, 43 p.

Peckham, A.E., 1986, Evaluation of GSX Services of South Carolina, Inc., Genstar Corporation, Pinewood, South Carolina: United States Environmental Protection Agency Hazardous Waste Ground Water Task Force, EPA-330/2-86-009, 65 p.

South Carolina Department of Health and Environmental Control, 1987, Hazardous waste management Regulations 61-79, Part 264, Appendix IV.

South Carolina Water Resources Commission, 1983, South Carolina water assessment: Water Resources Commission Report No. 140, 367 p.

U.S. Environmental Protection Agency, 1986, Quality criteria for water: EPA 440/5-86-001, 398 p.

Wershaw, R.L., Fishman, M.J., Grabbe, R.R., and Lowe, L.E., 1987, Methods for the determination of organic substances in water and fluvial sediments: U.S. Geological Survey Techniques of Water-Resources Investigations $5-\mathrm{A3}, 173 \mathrm{p}$.

Wood, W.W., 1976, Guidelines for collection and field analysis of groundwater samples for selected unstable constituents: U.S. Geological Survey Techniques of Water-Resources Investigations 1-D2, $24 \mathrm{p}$. 


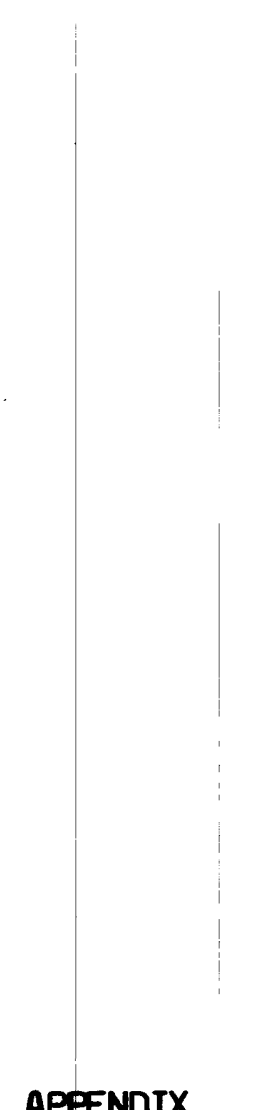

Station Descriptions 


\section{Station 3}

(USGS No. 02169860)

\section{Location}

Lat $33^{\circ} 42^{\prime} 22^{\prime \prime}$, long $80^{\circ} 32^{\circ} 18^{\prime \prime}$, NE $\frac{1}{4}$ of Elloree NE $7.5^{\circ}$ Quadrangle, Sumter County, Hydrologic Unit 03050111. "The gage is located on the left bank at the upstream side of the county road leading to Sparkleberry Landing, approximately 75 yards from the shoreline of Lake Marion, 3.2 miles northwest of Rimini, S.C., and $2.3 \mathrm{mi}$ west of Sumter County Road 43-51.

The station can be reached by driving north on Road 43-51, $2.9 \mathrm{mi}$ from Rimini, S.C., then west $1.5 \mathrm{mi}$ along Sparkleberry Landing Road.

\section{Period of Record}

The stage recording station was established on September 23, 1987, by the U.S. Geological Survey, Water Resources Division.

The period of record documented in this report is from October 14, 1987, to January 5, 1989.

\section{Drainage Area}

$0.07 \mathrm{mi}^{2}$

\section{Gage}

The gage is equipped with a Fisher-Porter digital stage recorder with a solid-state timer set for 30-minute punch intervals. The recorder is housed in a $34-$ by 24 - by 20 -inch metal shelter on top of an 8-inch diameter PVC stilling well into which a covered door for cleaning was installed.

An outside enameled staff gage, 0 to $3.34 \mathrm{ft}$, is attached to the stilling well support.

A crest stage gage is located on the right bank at the downstream side of Sparkleberry Landing Road. Head of pin elevation is $0.014 \mathrm{ft}$, gage datum.

\section{History}

No other gages have been operated on this stream. 


\section{Vertical Control Reference and Bench Marks}

RM-1 A chiseled square on top of the upstream end of a 4-ft concrete culvert located $5 \mathrm{ft}$ downstream of the gage. Elevation is $4.466 \mathrm{ft}$, gage datum.

RM-2 Head of a 3/8-inch nail, $2 \mathrm{ft}$ above land surface in the south side of a 9-inch oak tree located approximately $19 \mathrm{ft}$ north of the gage. Elevation is $5.730 \mathrm{ft}$, gage datum.

RM-3 Head of a 3/8-inch nail, $2.5 \mathrm{ft}$ above land surface in the west side of a 12-inch pine tree located approximately $20 \mathrm{ft}$ south of the gage. Elevation is $7.272 \mathrm{ft}$, gage datum.

RP-1 Bottom of V-notch in weir. Elevation is $0.472 \mathrm{ft}$, gage datum.

RP-2 Bottom lip of the gage house at the center elevation is 8.115 $\mathrm{ft}$, gage datum.

Present gage datum is arbitrary.

\section{Cooperation}

The U.S. Geological Survey and the South Carolina Public Service Authority cooperative project financed gage operation from September 23, 1987, to January 5, 1989. The U.S. Geological Survey operated the gage.

\section{Channel and Control}

The channel bends slightly to the right at the gage before flow enters a 4-ft diameter concrete culvert. The channel bottam is composed of sand. There is grass on the edges of the channel, and the banks are sparsely wooded. The channel is relatively permanent; however, it is slightly dynamic due to shifting sand.

The control is a V-notch weir located $5 \mathrm{ft}$ downstream of the gage on the upstream opening of a $4-\mathrm{ft}$ diameter concrete culvert.

\section{Discharge Measurements}

Discharge is measured by wading 15 to $25 \mathrm{ft}$ upstream of the gage. An alternate measuring section is located about $50 \mathrm{ft}$ downstream of the gage. All stages can be waded. Volumetric measurements can be made at the weir.

\section{Floods}

No known flood history. 


\section{Point of Zero Flow}

Bottom of $v$ in $V$-notch weir. $0.47 \pm 0.04 \mathrm{ft}$, gage datum.

\section{Winter Flow}

No ice effect,owing to swift flow.

\section{Regulation and Diversion}

None upstream of the gage.

A 4-ft diameter culvert diverts the flow beneath a county road immediately downstream of the gage.

\section{Accuracy}

Poor, owing to sediment accumulations in the gage pool and occasional poor current meter measurement conditions.

\section{Station 4}

(USGS No. 02169870)

\section{Location}

Lat $33^{\circ} 41^{\circ} 48^{\prime \prime}$, long $80^{\circ} 31^{\circ} 40^{\prime \prime}$, NE $\frac{1}{4}$ of Elloree NE $7.5^{\circ}$ Quadrangle, Sumter County, Hydrologic Unit 03050111. The gage is located on the earthen dam below the southernmost pond on the Touchberry property approximately 2.5 miles northwest of Rimini. The station can be reached by way of the Touchberry driveway $1.1 \mathrm{mi}$ west of the entrance, which is $2.2 \mathrm{mi}$ north of Rimini on Sumter county Road 43-51. The station can also be reached by foot from the west end of the northern boundary fence of the landfill site by traveling approximately 50 yards to the north.

\section{Period of Record}

The stage recording station was established on September 22, 1987, by the U.S. Geological Survey, Water Resources Division. The period of record documented in this report is from September 23, 1987, to January 5, 1989.

\section{Drainage Area}

$1.52 \mathrm{mi}^{2}$. 
The gage is equipped with a Fisher-Porter digital stage recorder with a solid-state timer set for 30-minute punch intervals. The recorder is housed in a 35 - by 24 - by 20 -inch metal shelter on top of an 8 -inch diameter PVC stilling well. A l-inch diameter PVC intake pipe extends into the pond and connects with an 8-inch diameter PVC sand trap with a removable Iid. An outside enameled staff gage, 0 to $6.74 \mathrm{ft}$, is fastened to a wooden support in the pond about $9 \mathrm{ft}$ from the gage.

\section{History}

One other gage is operated on this stream. It is located approximately $1,200 \mathrm{ft}$ downstream from station 4. This gage, at station 5, is also operated by the U.S. Geological Survey.

\section{Vertical Control Reference and Bench Marks}

RM-1 Head of a 3/8-inch nail $3 \mathrm{ft}$ above land surface in the north side of a 12-inch oak tree located approximately $25 \mathrm{ft}$ south of the gage. Elevation is $8.344 \mathrm{ft}$, gage datum.

RM-2 Head of a 3/8-inch nail $2.5 \mathrm{ft}$ above land surface in the west side of a 24-inch pine tree located approximately $103 \mathrm{ft}$ east of the gage. Elevation is $12.360 \mathrm{ft}$, gage datum.

RM-3 Head of a 3/8-inch nail $2.5 \mathrm{ft}$ above land surface in the west side of a 36-inch oak tree located approximately $105 \mathrm{ft}$ east of the gage. Elevation is $11.342 \mathrm{ft}$, gage datum.

RP-1 Bottom Iip of the gagehouse at the center. Elevation is 8.578, gage datum.

RP-2 Center edge of ADR shelf. Elevation is $9.074 \mathrm{ft}$. Present gage datum is arbitrary.

\section{Channel and Control}

The channel is well defined and relatively straight. One channel exists at all stages. The channel bottom consists of sand and gravel, and the banks are wooded.

Control at all stages is a vertical 4-ft diameter corrugated steel spillway pipe located in the pond approximately $10 \mathrm{ft}$ from the bank of the dam. The vertical spillway pipe connects ta a horizontal 4-ft corrugated steel pipe that passes through the earthen dam and exits into a $15-\mathrm{ft}$ diameter pool at the upper end of the stream channel. 


\section{Discharge Measurements}

Discharge is measured by wading 100 to $150 \mathrm{ft}$ downstream of the gage. All stages can be waded. Volumetric measurements can be made at the downstream end of the culvert.

\section{Floods}

No known flood history.

\section{Point of Zero Flow}

Not determined

\section{Winter Flow}

Possibility of ice effect in the event of the pond freezing.

\section{Regulation and Diversion}

The stream is dammed to form a small pond at the location of the gaging station and also at another point 2,000 ft upstream. A tributary discharges to the downstream pond from the east and also is dammed at a point 1,000 ft upstream of the gaging station (fig. 2).

\section{Accuracy}

Poor, owing to flows less than $3 \mathrm{ft}^{3} / \mathrm{s}$.

\section{Cooperation}

The U.S. Geological Survey and the South Carolina Public Service Authority cooperative project financed gage operation from September 22, 1987, to January 5, 1989. The U.S. Geological Survey operated the gage.

\section{Station 5}

(USGS No. 02169875)

\section{Location}

Lat $33^{\circ} 41^{\prime} 35^{\prime \prime}$, long $80^{\circ} 31^{\prime \prime} 45^{\prime \prime}$, NE $\frac{1}{4}$ of Elloree NE Quadrangle, sumter County, Hydrologic Unit 030501ll. The gage is located on the right bank of an unnamed stream, 1,200 ft downstream of Station 4 on the boundary line of the Santee-Cooper Reservation and the landfill site, and immediately west of the landfill spoil bluff ( $2.3 \mathrm{mi}$ northwest of Rimini). 
The station can be reached by driving northwest along the western perimeter road at the landfill, below the spoil bluff, and then by foot path for approximately 500 yards.

\section{Period of Record}

The stage recording station was established on September 22, 1987, by of the U.S. Geological Survey, Water Resources Division. The period of record documented in this report is from September 23, 1987, to January 5, 1989.

\section{Drainage Area}

$$
1.64 \mathrm{mi}^{2} \text {. }
$$

\section{Gage}

The gage is equipped with a Fisher-Porter digital stage recorder with a solid-state timer set for 30-minute punch intervals. The recorder is housed in a 33 - by 24 - by 20 -inch metal shelter on top of an 8-inch diameter PVC stilling well. A l-inch diameter PVC intake pipe, approximately $9.5 \mathrm{ft}$ in length, connects the stilling well to an 8-inch PVC sand trap, positioned in the center of the channel. The sand trap has a removable lid for cleaning. An outside enameled staff gage, 0 to $3.34 \mathrm{ft}$ is fastened to a wooden support adjacent to the right bank.

\section{History}

One other gage was operated on this stream at a site (station 4) approximately $1,200 \mathrm{ft}$ upstream of this gaging station.

Periodic instantaneous discharge measurements, not correlated to stage measurements, have been made near station 5 by the South Carolina Public Service Authority.

\section{Vertical Control Reference and Bench Marks}

RM-1 Head of a 3/8-inch nail $2.5 \mathrm{ft}$ above land surface in the south side of a 12-inch tree located $2 \mathrm{ft}$ northwest of the gage. Elevation is $4.982 \mathrm{ft}$, gage datum.

RM-2 Head of a 3/8-inch nail $2 \mathrm{ft}$ above land surface in the north side of a 15-inch tree located approximately $9 \mathrm{ft}$ northwest of the gage. Elevation is $4.616 \mathrm{ft}$, gage datum. 
RM-3 Head of a 3/8-inch nail $3 \mathrm{ft}$ above land surface in the east side of a 20-inch tree located approximately $30 \mathrm{ft}$ downstream of gage and $3 \mathrm{ft}$ from the right bank. Elevation is $5.291 \mathrm{ft}$, gage datum.

RP-1 Bottom lip of the gagehouse at the center. Elevation is 5.534, gage datum.

RP-2 Center edge of ADR shelf. Elevation is $6.105 \mathrm{ft}$, gage datum. Present gage datum is arbitrary.

Channel and Control

The channel is straight at the gage. It bends slightly to the left about $25 \mathrm{ft}$ upstream. The channel bottom is composed of sand, and the banks are wooded. The channel is permanent but subject to shifting sand.

Control at all stages is the natural channel.

\section{Discharge Measurements}

Discharge can be measured by wading approximately $25 \mathrm{ft}$ downstream of the gage. All stages can be waded.

\section{Floods}

No known flood history.

\section{Point of Zero Flow}

Not determined

\section{Winter Flow}

No ice effect

\section{Regulation and Diversion}

The stream is dammed at three places, forming ponds $600 \mathrm{ft}, 1,200 \mathrm{ft}$, and $2,000 \mathrm{ft}$ upstream of station 5. A tributary to the stream is also dammed $2,200 \mathrm{ft}$ upstream of station 5. A French drain, constructed along the northern part of the landfill facility (fig. 3), discharges to the stream immediately above the most-downstream pond. 


\section{Accuracy}

Poor owing to sediment accumulations in the gage pool and occasional poor current meter measurement conditions.

\section{Cooperation}

The U.S. Geological Survey and South Carolina Public Service Authority cooperative project financed gage operation from September 22, 1987, to January 5, 1989. The U.S. Geological Survey operated the gage.

\section{Station 6}

(USGS No. 02169880)

\section{Location}

Lat $33^{\circ} 41^{\prime} 24^{\prime \prime}$, long $80^{\circ} 31^{\circ} 39^{\prime \prime}$, NE $\frac{1}{4}$ of Elloree NE $7.5^{\circ}$ Quadrangle, Sumter County, Hydrologic Unit 03050111." The gage is located on the left bank at the downstream end of a 4-ft diameter corrugated steel culvert on the western edge of the landfill site and approximately $25 \mathrm{ft}$ east of the Santee-Cooper Reservation boundary.

The station can be reached by driving $1.6 \mathrm{mi}$ north of Rimini on County Road 43-51, then west approximately $1 \mathrm{mi}$ along the western perimeter road of the landfill site.

\section{Period of Record}

The stage recording station was established on December 23, 1987, by the U.S. Geological Survey, Water Resources Division. The period of record documented in this report is from December 24, 1987, to January 5, 1989.

\section{Drainage Area}

$$
0.40 \mathrm{mi}^{2} \text {. }
$$

\section{Gage}

The gage is equipped with a Fisher-Porter digital stage recorder with a solid-state timer set for 30-minute punch intervals. The recorder is housed in a 32 - by 24 - by 20 -inch metal shelter on top of a 1-ft aluminum stilling well. A 1.5-inch intake pipe extends $2 \mathrm{ft}$ out from the stilling well, makes a 90 degree turn upstream, enters a steel V-notch weir at the end of a 5-ft long, trough-shaped culvert extension, and extends $2.5 \mathrm{ft}$ into this extension, providing hydraulic connection between the stream and the recorder float. 
A portable outside enamel staff gage, 0 to $3.34 \mathrm{ft}$, has been fashioned to fit inside the trough-shaped culvert extension.

\section{History}

No other gages have been operated on this stream. Periodic instantaneous-discharge measurements, not correlated to stage measurements, have been made near Station 6 by the South Carolina Public Service Authority.

\section{Vertical Control Reference and Bench Marks}

RM-1 Head of a 3/8-inch nail $3.5 \mathrm{ft}$ above land surface in the south side of an 18-inch oak tree located approximately $140 \mathrm{ft}$ north of the gage. Elevation is $3.888 \mathrm{ft}$, gage datum.

RM-2 Head of a 3/8-inch nail $3.5 \mathrm{ft}$ above land surface in the south side of a 16-inch pine tree located approximately $125 \mathrm{ft}$ north of the gage. Elevation is $3.882 \mathrm{ft}$, gage datum.

RM-3 Exposed square on a ridge of an asphalt covered, 4-ft diameter corrugated steel culvert (painted orange) located approximately $6 \mathrm{ft}$ east of the gage. Elevation is $3.606 \mathrm{ft}$, gage datum.

RP-1 Top of culvert extension on the downstream edge. Elevation is $3.575 \mathrm{ft}$, gage datum.

RP-2 Left bank corner of culvert extension. Elevation is $1.618 \mathrm{ft}$, gage datum.

RP-3 Right bank corner of culvert extension. Elevation is $1.694 \mathrm{ft}$, gage datum.

RP-4 Bottom of V-notch in culvert. Elevation is $0.593 \mathrm{ft}$, gage datum.

RP-5 Bottom lip of gagehouse at its center. Elevation is $4.795 \mathrm{ft}$, gage datum.

RP-6 ADR shelf on center edge. Elevation is $5.324 \mathrm{ft}$, gage datum. Present gage datum is arbitrary.

\section{Channel and Control}

The channel is relatively straight at the gage. It bends to the right about $25 \mathrm{ft}$ downstream and to the left about $35 \mathrm{ft}$ downstream. A 4-ft diameter, corrugated-steel culvert empties immediately downstream of the gage (the gage measures stage in the culvert). Approximately $50 \mathrm{ft}$ downstream of the gage, the channel disperses and braids through a low-lying wooded area. The banks immediately adjacent to the gage are heavily 
riprapped, as is the channel bottom. Fifteen feet downstream, the left bank is vegetated with small trees and large shrubs. The right bank is vegetated with tall grass and large shrubs. The channel bottom is diverse. The riprapped section mentioned above is followed by a heavily silted section, which is then followed by a section of sand and gravel. The channel is basically stable; however, it can be changed slightly by a period of extremely high flow. The channel is subject to heavy sedimentation and, in warm months, to heavy aquatic growth.

\section{Discharge Measurements}

Discharge is measured by wading approximately $50 \mathrm{ft}$ downstream of the gage. All stages can be waded.

\section{Floods}

No known flood history.

Point of Zero Flow

$0.59 \pm 0.02 \mathrm{ft}$, gage datum.

\section{Winter Flow}

No ice effect.

\section{Regulation and Diversion}

There is a sedimentation pond approximately 150 yards upstream of the gage. Periodically, large amounts of water are pumped out of this pond for sprinkling dirt roads on the landfill site. The stream may also receive occasional discharges from landfill activities such as onsite production wells.

\section{Accuracy}

Poor, owing to flows less than $10 \mathrm{ft}^{3} / \mathrm{s}$.

\section{Cooperation}

The U.S. Geological Survey and the South Carolina Public Service Authority cooperative project financed gage operation from December 23 , 1987, to January 5, 1989. The U.S. Geological Survey operated the gage. 


\section{Station 7}

(USGS No. 334122080312400 )

\section{Location}

Lat $33^{\circ} 41^{\circ} 22^{\prime \prime}$, long $80^{\circ} 32^{\circ} 18^{\prime \prime}$, NE $\frac{1}{4}$ of Elloree NE $7.5^{\circ}$ Quadrangle, Sumter County, Hydrologic Unit 03050111. The gage is located on the west side of and within the landfill site, $1.9 \mathrm{mi}$ northwest of Rimini, S.C.

\section{Period of Record}

The cumulative rainfall recording station was established December 23, 1987, by the U.S. Geological Survey, Water Resources Division. The period of record recorded in this report is from December 24,1987 , to January 5 , 1989.

\section{Gage}

The gage is equipped with a Fisher-Porter digital cumulative rainfall recorder with a solid-state timer set for 30-minute punch intervals. The recorder is housed in a metal shelter on top of a metal collection pipe. An 8 -inch funnel connected to the top of the shelter is $7.75 \mathrm{ft}$, above land surface and collects the rainfall, directing it to the calibrated collection pipe. The water level in the collection pipe is monitored with a float, which is connected to the recorder.

\section{Obstructions}

The gage is located on an unwooded hill and is unobstructed.

\section{Cooperation}

The U.S. Geological Survey and the South Carolina Public Service Authority cooperative project financed gage operation from December 23, 1987, to January 5, 1989. The U.S. Geological Survey operated the gage. 